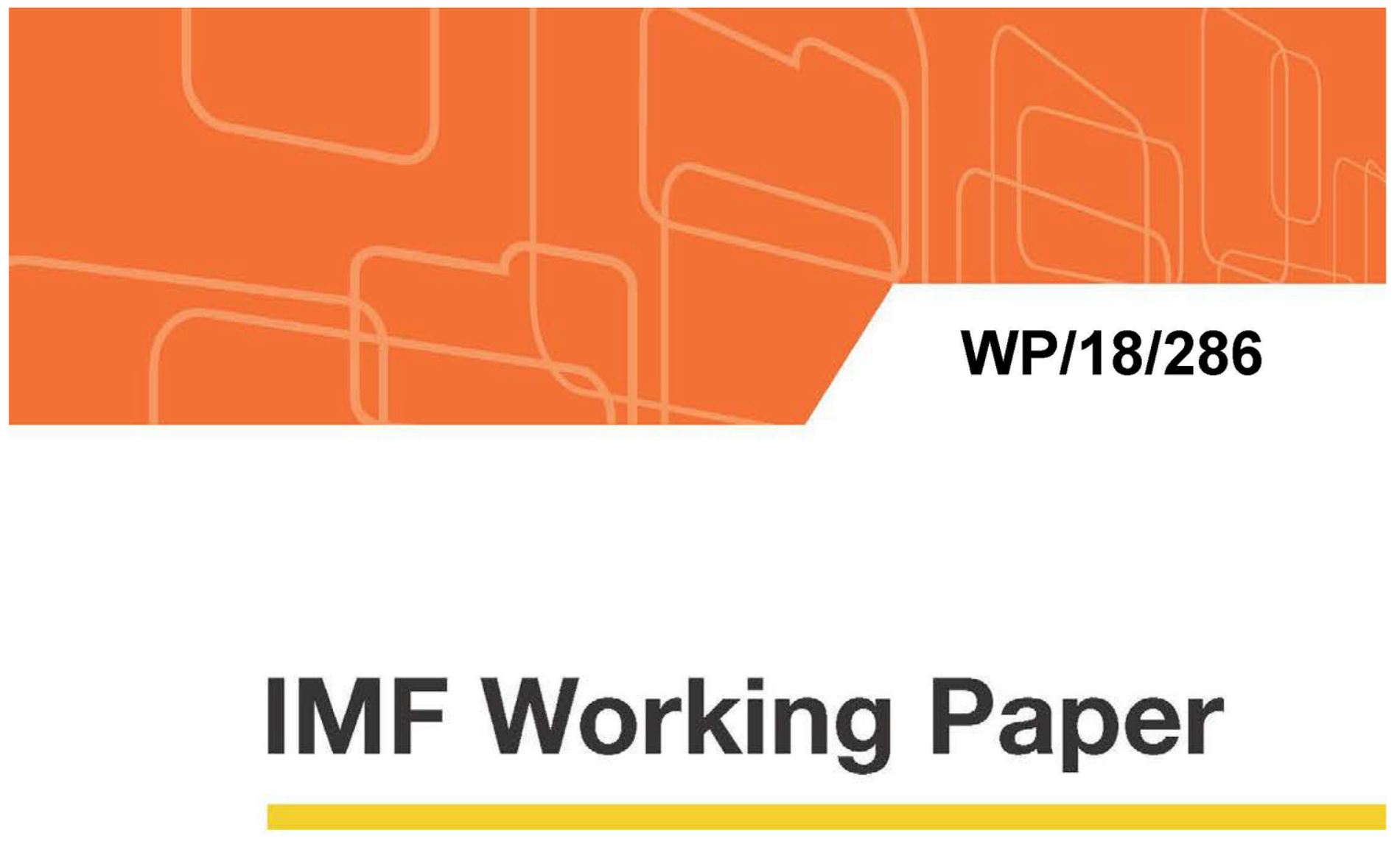

\title{
In Search of Information: \\ Use of Google Trends' Data to Narrow Information Gaps for Low-income Developing Countries
}

by Futoshi Narita and Rujun Yin

IMF Working Papers describe research in progress by the author(s) and are published to elicit comments and to encourage debate. This paper is part of a research project on macroeconomic policy in low-income countries supported by the U.K.'s Department for International Development (DFID). The views expressed in IMF Working Papers are those of the author(s) and do not necessarily represent the views of the IMF, its Executive Board, IMF management, or the DFID. 


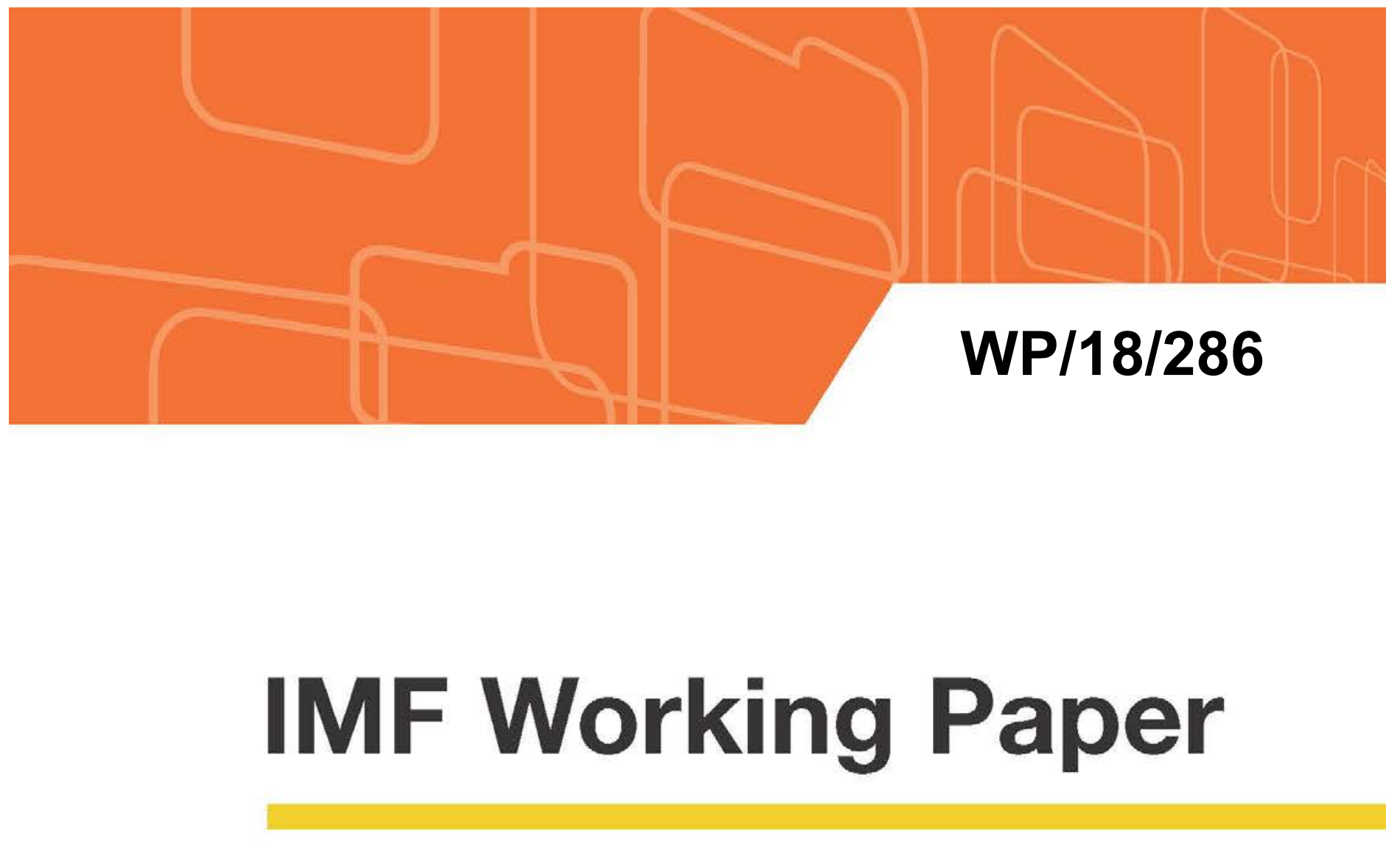

\section{In Search of Information: Use of Google Trends' Data to Narrow Information Gaps for Low-income Developing Countries}

by Futoshi Narita and Rujun Yin

IMF Working Papers describe research in progress by the author(s) and are published to elicit comments and to encourage debate. This paper is part of a research project on macroeconomic policy in low-income countries supported by the U.K.'s Department for International Development (DFID). The views expressed in IMF Working Papers are those of the author(s) and do not necessarily represent the views of the IMF, its Executive Board, IMF management, or the DFID.

$$
\text { I N T ER N A T I O N A L M O N E T A R Y FUN D }
$$




\title{
IMF Working Paper
}

Research Department and Strategy, Policy, and Review Department

\section{In search of information: use of Google trends' data to narrow information gaps for low-income developing countries*}

\section{Prepared by Futoshi Narita and Rujun Yin}

Authorized for distribution by Ali Mansoor and Chris Papageorgiou

December 2018

\section{IMF Working Papers describe research in progress by the author(s) and are} published to elicit comments and to encourage debate. This paper is part of a research project on macroeconomic policy in low-income countries supported by the U.K.'s Department for International Development (DFID). The views expressed in IMF Working Papers are those of the author(s) and do not necessarily represent the views of the IMF, its Executive Board, IMF management, or the DFID.

\begin{abstract}
Timely data availability is a long-standing challenge in policy-making and analysis for lowincome developing countries. This paper explores the use of Google Trends' data to narrow such information gaps and finds that online search frequencies about a country significantly correlate with macroeconomic variables (e.g., real GDP, inflation, capital flows), conditional on other covariates. The correlation with real GDP is stronger than that of nighttime lights, whereas the opposite is found for emerging market economies. The search frequencies also improve out-of-sample forecasting performance albeit slightly, demonstrating their potential to facilitate timely assessments of economic conditions in low-income developing countries.

JEL Classification Numbers: O11, O47, O57, E37, F17, F37

Keywords: Capital flows, Economic growth, Google search volume index, Inflation, Lowincome developing countries, Nighttime lights, Nowcasting, Short-term forecasting Author's E-Mail Address: fnarita@imf.org (Futoshi Narita), ryin@imf.org (Rujun Yin)

\footnotetext{
* Acknowledgment: We deeply thank Mamoon Saeed, Kei Moriya, and the Google Trends support team for their excellent technical support and Karina Chavez for her diligent editorial assistance. We also thank Sebastian Acevedo, Emre Alper, Claudia Berg, Alessandro Cantelmo, Rupa Duttagupta, Stefania Fabrizio, Rahul Giri, Wei Guo, Daniel Gurara, Roland Kpodar, Sandra Lizarazo Ruiz, Ali Mansoor, Marco Marini, Giovanni Melina, Machiko Narita, Neree Noumon, Chris Njuguna, Chris Papageorgiou, Saad Quayyum, Mahvash Qureshi, Alessandro Rebucci, Sidra Rehman, and the internal seminar participants in our unit and division for their thoughtful comments and suggestions. We are responsible for any remaining errors.
} 
I. INTRODUCTION

Table 1. Use of Google's SVI in forecasting/nowcasting economic variables

II. SEARCH VOLUME INDEX FOR A COUNTRY

Figure 1. SVI under the travel category and tourist arrivals in Myanmar.

III. CAN GOOGLE'S SVIS IMPROVE FORECASTING PERFORMANCE FOR LIDCS? ...... $\underline{8}$

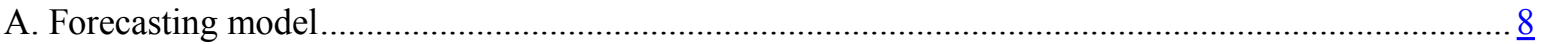

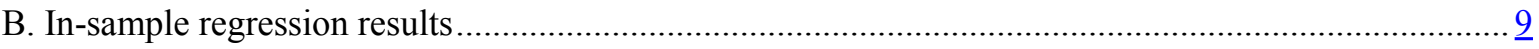

Table 2. Economic activities and the search volume index (SVI) in LIDCs...................................... 11

Table 3. Price developments and the search volume index (SVI) in LIDCs .......................................

Table 4. Capital flows and the search volume index (SVI) in LIDCs.............................................. $\frac{13}{13}$

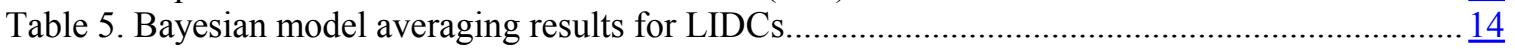

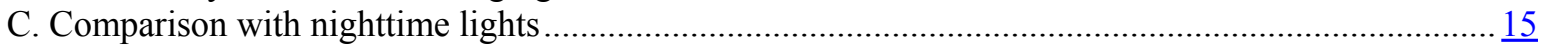

Table 6. Search volume index (SVI) and nighttime lights (NLs) ...............................................

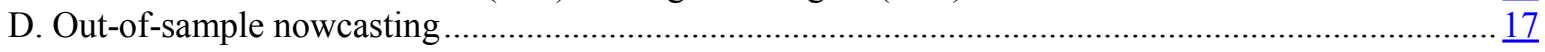

Table 7. Out-of-sample performance of nowcasting ......................................................................... 18

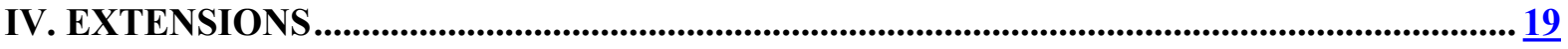

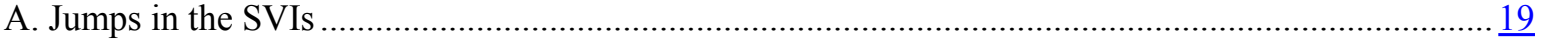

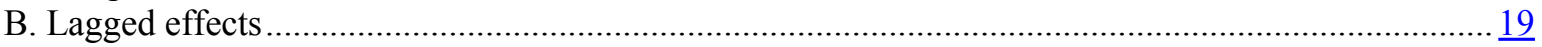

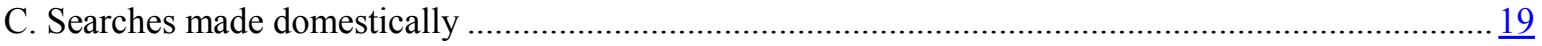

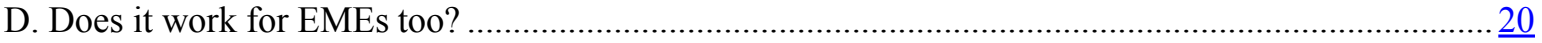

V. CONCLUSION

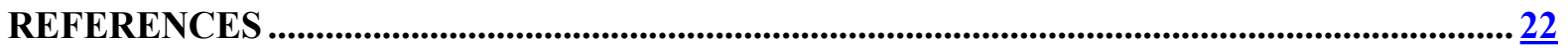

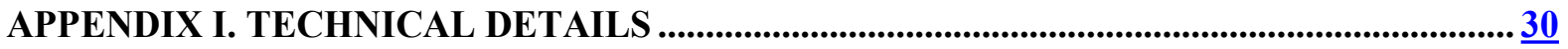

A. Introduction to Google's Search Volume Index (SVI) .................................................................. $\frac{30}{30}$

Appendix Figure 1. Google Trends search for "Kenya" as a search topic .......................................... $\underline{\underline{30}}$

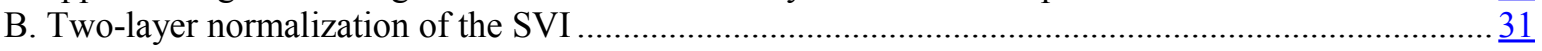

C. Making SVIs comparable..................................................................................................... $\frac{32}{33}$

D. Conditions for proper measurement of people's attention........................................................... $\frac{33}{34}$

Appendix Figure 2. Internet access, use of Google search, and people's attention.............................. $\underline{34}$

E. How to detect jumps in the SVIs..................................................................................................

APPENDIX II. SUPPLEMENTARY TABLES............................................................................... $\frac{38}{38}$

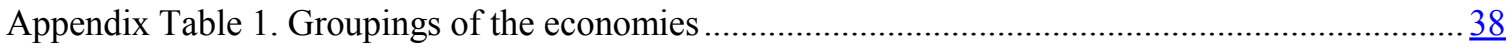

Appendix Table 2. Categories under the Google Trends service ...................................................... $\underline{39}$

Appendix Table 3. Variable definitions and data sources .............................................................

Appendix Table 4. Summary statistics for LIDCs .......................................................................

Appendix Table 5. Pairwise correlation coefficients for selected variables for LIDCs ........................ $\underline{42}$

Appendix Table 6. Nighttime lights (NLs) and real GDP in LIDCs .................................................. 43

Appendix Table 7. Nighttime lights (NLs) and real GDP in EMEs.................................................. 44

Appendix Table 8. Best specifications that minimize out-of-sample MSE for LIDCs ......................... 45

Appendix Table 9. Best specifications that minimize out-of-sample MSE for EMEs ………............... $\underline{46}$

Appendix Table 10. Regressions, excluding periods with jumps in SVIs, for LIDCs ......................... $\frac{47}{48}$

Appendix Table 11. Regressions with lagged SVIs for LIDCs........................................................ 48

Appendix Table 12. Regressions with domestically-made SVIs (DSVIs) for LIDCs ......................... 49

Appendix Table 13. Summary statistics for EMEs …….............................................................. $\frac{50}{51}$

Appendix Table 14. Regression Results for EMEs .................................................................... $\underline{51}$ 


\section{INTRODUCTION}

Timely data availability in low-income developing countries (LIDCs) is a long-standing challenge to researchers and policy makers. LIDCs have more missing data and longer time lags in data release than more developed economies. For example, as of July 2018 , official FDI data for 2017 are available only for less than half of LIDCs, compared to 90 percent for advanced economies. ${ }^{1}$ A survey of the IMF staff indicates severer deficiencies in data quality and availability for low-income countries (Independent Evaluation Office, 2016; Figure 2). The lack of reliable and timely information hampers real-time assessment of economic conditions and restricts the ability to set sound policies.

Nontraditional data sources—so-called big data—have proven to be useful in providing operationally valuable information in LIDCs. ${ }^{2}$ Satellite imagery data, such as nighttime lights, are used to measure economic growth and poverty in countries and sub-regions where data are scarce (Henderson, Storeygard, and Weil, 2012; Jean and others, 2016; Engstrom, Hersh, and Newhouse, 2017). In Kenya, researchers analyze mobile phone call records to help combat malaria more effectively (Wesolowski and others, 2012). A sensor technology generates usage statistics to improve performance of water pumps in Kenya and Ethiopia (Thomas and others, 2018, Table B.1).

This paper explores the potential of Google's search volume index (SVI) - a frequency of online search query submissions - to help narrow information gaps in LIDCs. Google's SVI would contain fruitful information about individuals' interests and attentions, considering the growing access to the Internet - especially, through mobile devices in developing countries - and Google's global user share of over 90 percent (StatCounter, 2018). People may search for information online to make economic decisions or to look for some economic developments. The SVI could capture these human behaviors in search of information, and that is the information potentially useful for economic analyses (see Appendix I, Section D, for discussion to formalize this idea). The information search could be more relevant for cross-border activities - travel, trade, foreign investment - that may face larger information barriers than local activities, and thus, it could be particularly useful for analyses on LIDCs, where such external economic activities play a key role (IMF, 2015a).

To the best of our knowledge, this is the first study to apply Google's SVIs to a macroeconomic analysis on a comprehensive set of developing countries. The existing literature focuses on the use of Google's SVI for more developed countries than LIDCs (Table 1). Following Choi and Varian (2012; a working paper version was released in 2009), many researchers started to use Google's SVI to forecast or nowcast socioeconomic

\footnotetext{
${ }^{1}$ The calculation is based on the International Financial Statistics database (IMF, 2018b). A fraction of missing values for FDI data since 2000 is 22 percent for LIDCs, compared to 12 percent for all the other non-LIDC economies. See Appendix Table 1 for the country groupings. Note that the situation has been improving, because of country authorities' own efforts and international initiatives to address data gaps, including G-20's Data Gaps Initiative (https://www.imf.org/en/Publications/SPROLLs/g20-data-gaps-initiative).

${ }^{2}$ In contrast to traditional data that are compiled for specific purposes, big data are collected as a byproduct of other activities (Hammer and others, 2017). The United Nations Economic Commission for Europe (UNECE) provides classification of big data (UNECE, 2013). The Week @ the Beach Index proposed by Laframboise and others (2014) is an example of the use of nontraditional data sources in economic analysis.
} 
Table 1. Use of Google's SVI in forecasting/nowcasting economic variables

Author (publication year)

Götz and Knetsch (2019)

Chamberlin (2010)

Carrière-Swallow and Labbé (2013)

Barreira, Godinho, and Melo (2013)

Askitas and Zimmermann (2009)

Fondeur and Karamé (2013)

Ross (2013)

Reis, Ferreira, and Perduca (2014)

Ferreira (2014)

Chadwick and Şengül (2015)

Vicente, López-Menéndez, and Pérez (2015)

Smith (2016)

D'Amuri and Marcucci (2017)

Vosen and Schmidt (2011)

$\mathrm{Wu}$ and Brynjolfsson (2015)

$\mathrm{Li}$, Shang, Wang, and Ma (2015)

Li, Ma, Wang, and Zhang (2015)

Bangwayo-Skeete and Skeete (2015)

Yang, Pan, Evans, and Lv (2015)

Li, Pan, Law, and Huang (2017)

Artola, Pinto, and de Pedraza García (2015)

Siliverstovs and Wochner (2018)

Rivera (2016)

Da, Engelberg, and Gao (2011)

Joseph, Wintoki, and Zhang (2011)

Preis, Moat, and Stanley (2013)

Vozlyublennaia (2014)

Takeda and Wakao (2014)

Tantaopas, Padungsaksawasdi, and

Treepongkaruna (2016)

Adachi, Masuda, and Takeda (2017)

Tang and Zhu (2017)

Welagedara, Deb, and Singh (2017)

Yung and Nafar (2017)

Vlastakis and Markellos (2012)

Smith (2012)

Aouadi, Arouri, and Teulon (2013)

Hamid and Heiden (2015)

Da, Engelberg, and Gao (2015)

Dimpfl and Jank (2016)

Moussa, Delhoumi, and Ouda (2017)

Goddard, Kita, Wang (2015)

Peltomäki, Graham, Hasselgren (2018)

Afkhami, Cormack, and Ghoddusi (2017)

Campos, Cortazar, Reyes (2017)

Koop and Onorante (2013)
Country under analysis

Germany

United Kingdom

Chile

France, Italy, Portugal, Spain

Germany

France

United Kingdom

France, Italy

Portugal

Turkey

Spain

United Kingdom

United States

United States

United States

China

United States

Caribbean countries

China

China

Spain

Switzerland

Puerto Rico

United States

United States

United States

United States

Japan

Six AEs and four EMEs

Japan

United States

United States

United States

United States

Eight AEs

France

United States

United States

United States

France

Five AEs

25 EMEs

United States

United States

United States
Variable to predict

GDP

Retail sales

Car sales

Car sales

Unemployment rate

Unemployment rate

Unemployment rate

Unemployment rate

Unemployment rate

Unemployment rate

Unemployment rate

Unemployment rate

Unemployment rate

Consumption

House price

Consumer price index

Oil prices

Tourist arrivals

Tourist arrivals

Tourist arrivals

Tourist arrivals

Tourist arrivals

Hotel registrations

Stock prices/returns

Stock prices/returns

Stock prices/returns

Stock prices/returns

Stock prices/returns

Stock prices/returns

Stock prices/returns

Stock prices/returns

Stock prices/returns

Real estate investment

trusts' (REITs) returns

Stock market volatility

Stock market volatility

Stock market volatility

Stock market volatility

Stock market volatility

Stock market volatility

Stock market volatility

Exchange rate volatility

Exchange rate volatility

Energy price volatility

Energy price volatility

Nine macroeconomic indicators

Source: Authors' survey.

Note: This list may not be exhaustive, and any omissions are purely incidental. See also Buono and others (2017) for a broader survey on the use of nontraditional data in macroeconomic nowcasting. AEs: advanced economies; EMEs: emerging market economies. 
indicators. ${ }^{3}$ The official statistical authorities and central banks have also adopted Google's SVIs and other big data for policy-making, data compilation, and economic research, but the efforts are still largely concentrated in advanced or frontier emerging economies (IMF, 2018d, Box 3). Our main analysis covers about 50 LIDCs (less than the total of 59 due to lack of macroeconomic data, while SVIs are available for all countries) and we also extend the analysis to about 80 other emerging and developing economies.

\section{We find that Google's SVI can provide useful information to enhance real-time} monitoring of economic conditions in LIDCs. We construct a panel data set of the SVI for each country by setting the country name as a search topic. And to be more granular, we further collect SVIs by category. For example, for Uganda, the SVI under the finance category increases if someone submits a query such as "Uganda exchange rate," other things being equal. We choose five categories (finance; business and industrial; law and government; health; travel) and find in-sample significance of some of these SVIs in simple regression models of contemporaneous forecasting (i.e., nowcasting) that predict macroeconomic variables, conditional on lagged covariates. The use of these SVIs also improves out-of-sample performance, albeit slightly, measured by the mean of squared forecasting errors, computed by recursive forecasting regressions.

Using SVIs under various categories altogether seems to help disentangle positive and negative effects from the changes in individuals' attentions to a country. The fact that SVIs may signal confounded offsetting effects has been an issue in the application of the SVI (e.g., see Vozlyublennaia, 2014; page 18). In normal time, people may pay attention to a country if they are involved in some activities in the country, such as, searching for accommodations. This way, SVIs help identify positive effects on the country's economy. However, people may also pay attention because of natural disasters, conflicts, epidemics, scandals, etc. These events are rather associated with negative effects on the economy. Combining SVIs under different categories may help separate these offsetting effects, albeit not perfectly (Scott and Varian, 2015; Acevedo, 2016). We generally find that the businessand-industrial and travel categories tend to be associated with positive effects, whereas the finance, law-and-government, and health categories tend to indicate negative effects.

\section{The SVIs show stronger correlation with real GDP than that of nighttime lights for LIDCs, while the opposite is found for emerging market economies (EMEs). The} significance of SVIs in the regressions for real GDP shows a stark contrast with the results for nighttime lights extracted from satellite imagery (Henderson, Storeygard, and Weil, 2012), which lost significance once lagged covariates are included in the regressors. This is striking, because nighttime lights are well accepted as a proxy to economic activity in the development literature. For EMEs, however, nighttime lights significantly correlate with real GDP while SVIs are not as significant as in the case of LIDCs. This contrasting finding may indicate some structural differences between LIDCs and EMEs.

\footnotetext{
${ }^{3}$ Active areas of research include finance (predicting stock price and volatility, following a seminal paper of an "attention index" by Da, Engelberg, and Gao, 2011); health (including the famous Google Flu Trend by Gingsberg and others, 2009, and its refinement by Lampos and others, 2015); tourism (forecasting tourist arrivals); sociology (measuring issue salience); and political science (voting behaviors). IMF (2015c, Figure 2) uses SVIs to illustrate tourism demand to Samoa.
} 
In addition to these new empirical findings, this paper also contributes to the literature by providing a foundation for interpreting the SVI. The paper formalizes the underlying conditions where Google's SVI could be associated with people's attention to the entities represented by a query (Appendix I, Section D). These conditions clarify what can be captured by the SVI and what kind of biases the SVI is subject to, filling the gap in the literature and providing a solid basis for the empirical research using SVIs in general.

The rest of the paper is structured as follows. Section II explains how we compile the data from the Google Trends service, while leaving technical details to Appendix I. Section III presents the main empirical results, including the comparison with nighttime lights in Section III.C. Section IV discusses several extensions, such as the results for EMEs in Section IV.D.

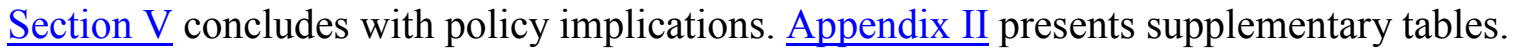

\section{SEARCH VOLUME INDEX FOR A COUNTRY}

The Google Trends service enables us to retrieve an SVI - a normalized measure of the search frequency — of a keyword or a topic. The SVI represents the number of search query submissions to the Google search engine on a keyword or a topic, relative to the total number of query submissions on all kinds of keywords. The SVI is further rescaled on a range of 0 to 100 so that the resulting time series of an SVI shows 100 at its maximum. We can specify the locations where the queries were submitted and the categories under which the searches were made. A search topic, rather than just a word, can be specified to resolve ambiguity due to homographs - e.g., word "Turkey" can mean a country or a bird (StephensDavidowitz and Varian, 2015)—by using Google's Knowledge Graph service. See Appendix I for more details.

\section{We use a country name as a search topic to obtain an SVI that proxies individuals' attention to a LIDC. The SVI based on a country name will increase if more search queries about the country are submitted to the Google servers than any other search queries. We argue that this SVI could reflect the number of people all over the world who get interested in something about the country (see Appendix I, Section D, for the conditions under which this claim would hold) and that we may be able to extract useful information about the country from the SVI. We use Google's Knowledge Graph service to resolve ambiguity of country names, including language issues (e.g. "Côte d'Ivoire" and "Ivory Coast") and adjust SVIs to make them comparable across countries (Appendix I, Section C). The SVIs constructed as such exhibit some positive correlation with the country income levels.}

To separate positive and negative sentiments, we retrieve SVIs by category. A common issue with the SVI is the difficulty in labeling search terms with positive or negative sentiment and identifying how they are linked to economic indicators. Among the 25 major categories, we choose five categories - finance; business and industrial; law and government; health; and travel - to capture searches related to economic activities (finance; business and industrial; travel) and at the same time to control for searches related to negative incidents that may adversely affect the economy (law and government; health). It is an empirical question how successful this strategy would be. Note that SVIs under more granular subcategories (as shown in Appendix Table 2) tend to return zeros due to lower search frequencies than Google's reporting threshold. 
Figure 1. SVI under the travel category and tourist arrivals in Myanmar

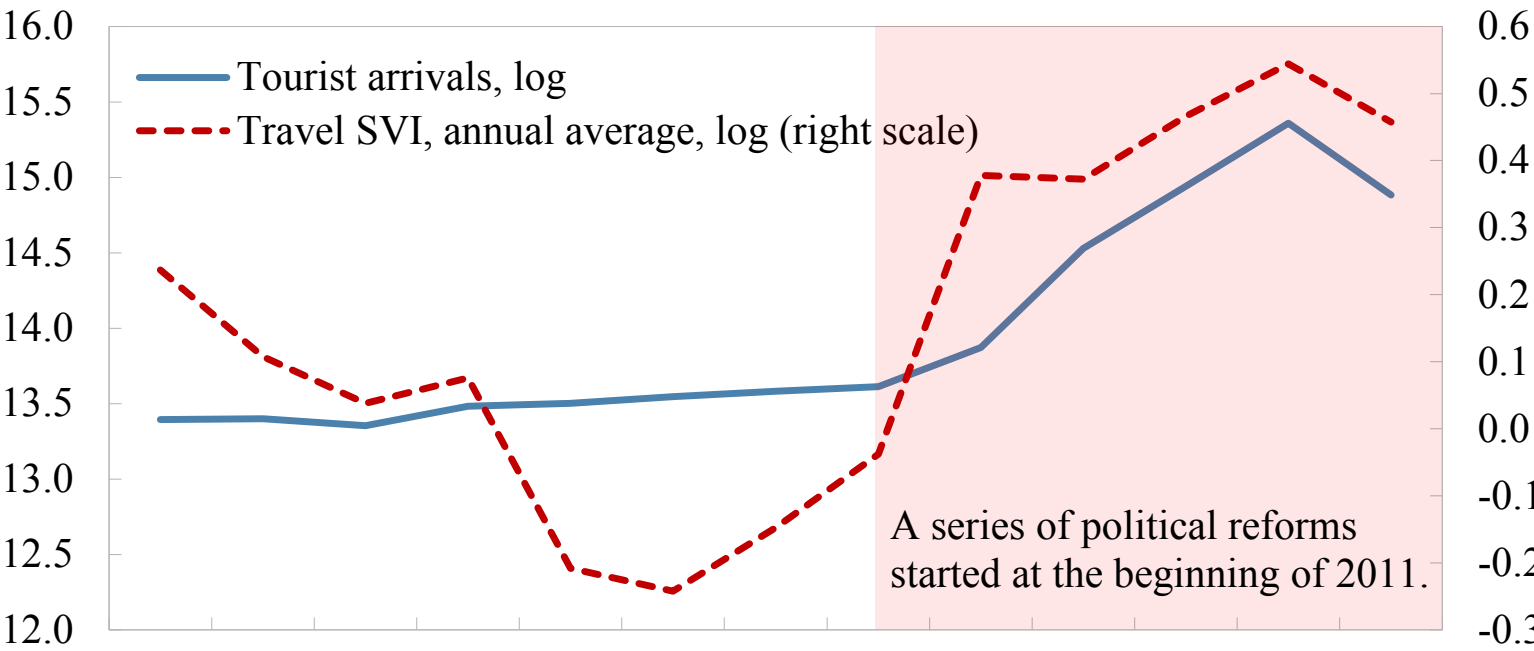

2004200520062007200820092010201120122013201420152016

Sources: Google Trends, World Development Indicators (World Bank, 2018), and the authors' calculations.

Some cases illustrate underlying relationships between SVIs and economic activities. For example, the SVI for Myanmar under the travel category seems to capture the increasing trend of tourist arrivals to Myanmar since 2011 (Figure 1). From the beginning of 2011, Myanmar underwent a series of political reforms (IMF, 2015b). The following sections investigate whether this conjecture could be generalized, based on regression analyses.

\section{CAN GOOGLE’S SVIS IMPROVE FORECASTING PERFORMANCE FOR LIDCs?}

\section{A. Forecasting model}

To examine potential of Google's SVIs, we consider a simple forecasting model using SVIs. We construct a panel data set of SVIs (the yearly averages of monthly data) from 2004 to 2017 for 59 LIDCs, combined with macroeconomic data taken from several databases (see Appendix Table 3 for variable definitions and data sources; Appendix Table 4 for summary statistics; and Appendix Table 5 for pairwise correlation coefficients for selected variables). We postulate a simple linear regression as follows:

$$
Y_{i t}=\rho Y_{i, t-1}+\beta \mathrm{SVI}_{i t}+\gamma X_{i, t-1}+\alpha_{i}+D_{t}+\varepsilon_{i t},
$$

where $Y_{i t}$ denotes a variable to predict (real GDP growth, real exports, travel arrivals, inflation, exchange rates, private capital inflows, FDI inflows); $\mathrm{SVI}_{i t}$ denotes a vector of SVIs under the selected five categories; $X_{i t}$ denotes a vector of other control variables; $\alpha_{i}$ and $D_{t}$ are country fixed effects and time dummies, respectively; and $\varepsilon_{i t}$ denotes the residuals. See Appendix Table 3 for how each variable is constructed and transformed (e.g., in natural logarithm or in percent change).

This specification is motivated by real-time assessment of the economy when only lagged data are available. We put control variables $X_{i t}$ with a one-year lag, whereas the SVIs are contemporaneous, because our purpose is to explore the benefits from timely observation of SVIs in real-time monitoring of the economy. For example, we consider a 
situation to assess real GDP growth for the year 2016 as of January 2017 when actual real GDP for 2016 was not available, although SVIs for 2016 were available. Control varibles $X_{i t}$ are chosen based on the empirical literature on variables to forecast (e.g., for economic growth regression, Barro, 2015; for the determinants of capital flows, Araujo and others, 2017; Hashimoto and Wacker, 2016; Choi and Hashimoto, 2018), although many of the control variables that are used in the literature are not included due to lack of observations for many LIDCs. For example, including the gross enrollment ratio to secondary education reduces the sample size by one-third, but the estimation results do not change significantly.

The purpose of the exercise is to find useful correlation between SVIs and economic variables, instead of establishing causality. Our simple model specification suffers from endogeneity due to any causalities from $Y_{i t}$ to $\mathrm{SVI}_{i t}$ and the so-called Nickell bias due to the inclusion of country fixed effects and the lagged dependent variable (e.g., see Barro, 2015). We do not address these issues because our purpose is to predict $Y_{i t}$ by modeling the expected value of $Y_{i t}$ conditional on all the information available, instead of estimating structural causation between variables of interest (see Kleinberg and others, 2015, for a useful distinction between prediction and causation). Also, high correlation across SVIs by category - ranging from 0.77 to 0.92 (Appendix Table 5) - would not be a matter of concern in predicting $Y_{i t}$. However, such high correlation would pose a challenge in separating the category SVIs into those that capture positive sentiments and those that capture negative sentiments.

\section{B. In-sample regression results}

We find some of the SVIs show significance in the simple forecasting model, contributing to a better fit of the model. We confirm that these findings are robust to the issue of sampling, conducted in constructing SVIs (see Appendix I for details), by repeating the same exercise for five separate vintages of the SVIs constructed during April-June 2018. For ease of exposition, we refer to the SVI under a category in a concise way; for example, the SVI under the business-and-industrial category is referred to the business-industrial SVI, and so on. Specific findings are as follows:

- $\quad$ Economic activities (Table 2). The business-industrial SVI exhibits a significant positive correlation with real GDP, indicating that a 10 percent increase in businessrelated attention would be associated with a 0.7 percent increase in real GDP. The law -government SVI and the health SVI, on the other hand, show significant negative correlations, implying that these SVIs may capture slowdowns in economic activities due to public concerns on legal, political, or health issues. These SVIs show a broadly similar pattern of correlation with real exports and tourist arrivals - with larger magnitudes - in line with a conjecture that people's attention from outside of the country is the source of the observed correlations. The travel SVI is positively correlated with tourist arrivals. We have also tried tourism receipts, but the correlation is not as robust as for tourist arrivals, possibly because the SVI is more associated with the number of people interested in visiting the country, rather than how much they spend in the country.

- $\quad$ Prices (Table 3). There is strong positive correlation between inflation and the finance SVI - a 10 percent increase in finance-related attention would be associated 
with an increase in inflation by 0.3 percentage points. The results for the nominal exchange rate imply that the finance SVI may reflect currency depreciation pressures and that its pass-through to inflation may explain the results for inflation. Correlation between the finance SVI and the real effective exchange rate (REER) is not significant, possibly due to relatively high pass-through in LIDCs. The lawgovernment SVI seems to be correlated with REER appreciation, which we admit is not so intuitive because the law-government SVI is negatively associated with economic activities (as is shown in Table 2). The travel SVI is significantly associated with lower prices, which would be due to people's travel interests to a destination with cheaper goods and services.

- Capital flows (Table 4). We find positive associations between gross capital inflows and the business-industrial SVI. Motivated by Araujo and others (2017), we separately examine FDI and non-FDI flows and find somewhat stronger correlation for non-FDI flows. The finance SVI show no significant association, possibly because the SVI may be more associated with individuals' behaviors (e.g., checking the exchange rate) and personal investment to these countries is not yet significant. The behaviors of institutional investors may be better captured by the business-industrial SVI. The travel SVI is negatively correlated with capital flows, which may reflect lower financing needs due to higher travel service receipts.

The findings are broadly robust to model uncertainty (Table 5). We employ the Bayesian model averaging (BMA) methodology to examine robustness of our findings to specification uncertainty (Leamer, 1978). The estimation is implemented using the Stata command bma (De Luca and Magnus, 2011). The results show that our findings are mostly robust to specification uncertainty, although the correlations with inflation and capital flows are not so strong as they appear in Tables 3 and $\underline{4}$. 
Table 2. Economic activities and the search volume index (SVI) in LIDCs

\begin{tabular}{|c|c|c|c|c|c|c|}
\hline \multirow[b]{2}{*}{ Dependent variables } & (1) & (2) & (3) & (4) & $(5)$ & (6) \\
\hline & \multicolumn{2}{|c|}{ Real GDP } & \multicolumn{2}{|c|}{ Real exports } & \multicolumn{2}{|c|}{ Tourist arrivals } \\
\hline \multirow[t]{2}{*}{ SVI: Finance } & & 0.00 & & -0.00 & & 0.01 \\
\hline & & $(0.01)$ & & $(0.04)$ & & $(0.08)$ \\
\hline \multirow[t]{2}{*}{ SVI: Business and industrial } & & $0.07 * * *$ & & $0.16^{*}$ & & 0.25 \\
\hline & & $(0.02)$ & & $(0.09)$ & & $(0.19)$ \\
\hline \multirow[t]{2}{*}{ SVI: Law and government } & & $-0.07 * * *$ & & $-0.20 * * *$ & & $-0.36 * * *$ \\
\hline & & $(0.02)$ & & $(0.07)$ & & $(0.11)$ \\
\hline \multirow[t]{2}{*}{ SVI: Health } & & $-0.03 * *$ & & -0.02 & & $-0.23 * *$ \\
\hline & & $(0.02)$ & & $(0.03)$ & & $(0.11)$ \\
\hline \multirow[t]{2}{*}{ SVI: Travel } & & 0.00 & & 0.02 & & $0.23 * *$ \\
\hline & & $(0.01)$ & & $(0.05)$ & & $(0.09)$ \\
\hline \multirow[t]{2}{*}{ Lagged dependent variable } & $0.85 * * *$ & $0.84 * * *$ & $0.83 * * *$ & $0.83 * * *$ & $0.68 * * *$ & $0.65 * * *$ \\
\hline & $(0.05)$ & $(0.05)$ & $(0.05)$ & $(0.05)$ & $(0.06)$ & $(0.06)$ \\
\hline \multirow[t]{2}{*}{ Population (lag) } & -0.03 & -0.01 & 0.15 & 0.29 & $-1.12 *$ & -0.65 \\
\hline & $(0.13)$ & $(0.12)$ & $(0.41)$ & $(0.44)$ & $(0.56)$ & $(0.47)$ \\
\hline \multirow[t]{2}{*}{ Internet users (lag) } & -0.00 & -0.00 & 0.02 & 0.02 & 0.02 & 0.04 \\
\hline & $(0.01)$ & $(0.00)$ & $(0.02)$ & $(0.02)$ & $(0.03)$ & $(0.03)$ \\
\hline \multirow[t]{2}{*}{ Real GDP (lag) } & & & $-0.28 *$ & $-0.31 *$ & -0.37 & $-0.48 * *$ \\
\hline & & & $(0.15)$ & $(0.16)$ & $(0.25)$ & $(0.23)$ \\
\hline \multirow[t]{2}{*}{ Trade openness (lag) } & 0.02 & 0.01 & -0.02 & -0.05 & $-0.24 * *$ & $-0.29 * * *$ \\
\hline & $(0.01)$ & $(0.01)$ & $(0.09)$ & $(0.08)$ & $(0.11)$ & $(0.10)$ \\
\hline \multirow[t]{2}{*}{ Fiscal spending (lag) } & $0.04 * * *$ & $0.03 * * *$ & 0.06 & 0.04 & $0.24 * * *$ & $0.22 * * *$ \\
\hline & $(0.01)$ & $(0.01)$ & $(0.05)$ & $(0.05)$ & $(0.07)$ & $(0.06)$ \\
\hline \multirow[t]{2}{*}{ REER, log level (lag) } & -0.03 & -0.03 & 0.10 & 0.09 & $-0.36 * * *$ & $-0.36 * * *$ \\
\hline & $(0.03)$ & $(0.03)$ & $(0.09)$ & $(0.09)$ & $(0.13)$ & $(0.11)$ \\
\hline \multirow[t]{2}{*}{ Inflation (lag) } & $-0.00^{*}$ & $-0.00 *$ & -0.00 & -0.00 & -0.00 & -0.00 \\
\hline & $(0.00)$ & $(0.00)$ & $(0.00)$ & $(0.00)$ & $(0.00)$ & $(0.00)$ \\
\hline \multirow[t]{2}{*}{ Trading partners' growth (lag) } & 0.00 & -0.00 & -0.00 & -0.00 & $0.03 * *$ & $0.03 * *$ \\
\hline & $(0.00)$ & $(0.00)$ & $(0.01)$ & $(0.01)$ & $(0.01)$ & $(0.01)$ \\
\hline \multirow[t]{2}{*}{ Export price growth (lag) } & 0.00 & 0.00 & 0.00 & 0.00 & -0.00 & -0.00 \\
\hline & $(0.00)$ & $(0.00)$ & $(0.00)$ & $(0.00)$ & $(0.00)$ & $(0.00)$ \\
\hline \multirow[t]{2}{*}{ Capital account openness (lag) } & 0.01 & -0.01 & 0.14 & 0.09 & $0.30 * * *$ & 0.18 \\
\hline & $(0.02)$ & $(0.02)$ & $(0.09)$ & $(0.09)$ & $(0.10)$ & $(0.12)$ \\
\hline \multirow[t]{2}{*}{ Age dependency ratio (lag) } & 0.00 & -0.00 & 0.00 & 0.00 & 0.01 & 0.01 \\
\hline & $(0.00)$ & $(0.00)$ & $(0.01)$ & $(0.00)$ & $(0.01)$ & $(0.01)$ \\
\hline Observations & 644 & 644 & 633 & 633 & 575 & 575 \\
\hline Number of countries & 53 & 53 & 53 & 53 & 52 & 52 \\
\hline Adjusted R-squared & 0.961 & 0.964 & 0.797 & 0.802 & 0.743 & 0.763 \\
\hline Country fixed effects & YES & YES & YES & YES & YES & YES \\
\hline Time dummies & YES & YES & YES & YES & YES & YES \\
\hline
\end{tabular}

Sources: Chinn and Ito (2006), Google Trends, International Financial Statistics (IMF, 2018b), World Development Indicators (World Bank, 2018), World Economic Outlook (IMF, 2018e), and the authors' estimation.

Note. Sample period: 2004-2016. Cluster-robust standard errors are reported in parentheses. Superscripts *, **, and *** indicate statistical significance at the 10 percent, 5 percent, and 1 percent level, respectively. See Appendix Table 1 for country groupings and Appendix Table 3 for variable definitions (most of variables are in natural logarithm or percent change) and data sources. LIDCs: low-income developing countries; REER: real effective exchange rate; SVI: search volume index. 
Table 3. Price developments and the search volume index (SVI) in LIDCs

\begin{tabular}{|c|c|c|c|c|c|c|}
\hline \multirow[b]{2}{*}{ Dependent variables } & (1) & (2) & (3) & (4) & (5) & (6) \\
\hline & \multicolumn{2}{|c|}{$\begin{array}{l}\text { Inflation } \\
\text { (percent change) }\end{array}$} & \multicolumn{2}{|c|}{$\begin{array}{l}\text { Nominal exchange rate } \\
\text { (local currencies to one U.S. } \\
\text { dollar, percent change) }\end{array}$} & \multicolumn{2}{|c|}{$\begin{array}{c}\text { REER } \\
\text { (percent change) }\end{array}$} \\
\hline \multirow[t]{2}{*}{ SVI: Finance } & & $3.36^{* * *}$ & & $7.83 * * *$ & & -2.49 \\
\hline & & $(1.04)$ & & $(2.32)$ & & $(1.68)$ \\
\hline \multirow[t]{2}{*}{ SVI: Business and industrial } & & $-2.93 *$ & & -0.57 & & -0.90 \\
\hline & & $(1.47)$ & & $(3.48)$ & & $(2.73)$ \\
\hline \multirow[t]{2}{*}{ SVI: Law and government } & & 0.48 & & $-5.72 * *$ & & $4.68 * *$ \\
\hline & & $(1.20)$ & & $(2.22)$ & & $(2.21)$ \\
\hline \multirow[t]{2}{*}{ SVI: Health } & & 1.53 & & 0.05 & & 0.19 \\
\hline & & $(0.99)$ & & $(1.58)$ & & $(1.38)$ \\
\hline \multirow[t]{2}{*}{ SVI: Travel } & & $-2.90 * *$ & & -2.99 & & 0.69 \\
\hline & & $(1.25)$ & & $(2.52)$ & & $(1.89)$ \\
\hline \multirow[t]{2}{*}{ Lagged dependent variable } & $0.34 * * *$ & $0.32 * * *$ & $0.13 * * *$ & $0.11 * * *$ & 0.04 & 0.04 \\
\hline & $(0.05)$ & $(0.05)$ & $(0.03)$ & $(0.03)$ & $(0.03)$ & $(0.04)$ \\
\hline \multirow[t]{2}{*}{ Population (lag) } & 0.25 & 0.09 & -6.19 & 1.65 & 14.24 & 10.67 \\
\hline & $(14.79)$ & $(15.96)$ & $(16.98)$ & $(18.78)$ & $(9.45)$ & $(11.28)$ \\
\hline \multirow[t]{2}{*}{ Internet users (lag) } & $0.96 * *$ & $0.82 *$ & 0.82 & 0.52 & -0.36 & -0.39 \\
\hline & $(0.42)$ & $(0.43)$ & $(0.81)$ & $(0.79)$ & $(0.69)$ & $(0.67)$ \\
\hline \multirow[t]{2}{*}{ Real GDP (lag) } & 0.75 & 1.49 & 2.59 & 3.40 & -1.43 & -1.43 \\
\hline & $(3.15)$ & $(3.16)$ & $(4.77)$ & $(5.00)$ & $(5.81)$ & $(5.45)$ \\
\hline \multirow[t]{2}{*}{ Trade openness (lag) } & -0.10 & 0.45 & $-6.89 * * *$ & $-6.37 * *$ & $7.23 * * *$ & $7.55 * * *$ \\
\hline & $(1.08)$ & $(1.08)$ & $(2.27)$ & $(2.45)$ & $(2.03)$ & $(2.22)$ \\
\hline \multirow[t]{2}{*}{ Fiscal spending (lag) } & -1.58 & -1.83 & $-3.62 *$ & $-5.04 * *$ & 2.22 & 2.90 \\
\hline & $(1.12)$ & $(1.14)$ & $(1.90)$ & $(1.95)$ & (2.19) & $(2.16)$ \\
\hline REER, percent change (lag) & $\begin{array}{c}-0.20 * * * \\
(0.03)\end{array}$ & $\begin{array}{c}-0.20 * * * \\
(0.03)\end{array}$ & & & & \\
\hline \multirow[t]{2}{*}{ Inflation (lag) } & & & $-0.09 * *$ & $-0.10 * *$ & $0.24 * *$ & $0.25 * *$ \\
\hline & & & $(0.04)$ & $(0.04)$ & $(0.11)$ & $(0.12)$ \\
\hline \multirow[t]{2}{*}{ Trading partners' growth (lag) } & -0.07 & -0.06 & -0.36 & -0.35 & -0.51 & -0.52 \\
\hline & $(0.21)$ & $(0.20)$ & $(0.32)$ & $(0.31)$ & $(0.33)$ & $(0.34)$ \\
\hline \multirow[t]{2}{*}{ Import price growth (lag) } & 0.06 & 0.08 & -0.11 & -0.12 & 0.17 & $0.20^{*}$ \\
\hline & $(0.06)$ & $(0.06)$ & $(0.09)$ & $(0.10)$ & $(0.11)$ & $(0.11)$ \\
\hline \multirow[t]{2}{*}{ Capital account openness (lag) } & -2.98 & -1.84 & -4.69 & -4.57 & 0.45 & 1.06 \\
\hline & $(3.10)$ & $(2.70)$ & $(4.15)$ & $(3.52)$ & $(3.15)$ & $(3.06)$ \\
\hline \multirow[t]{2}{*}{ Age dependency ratio (lag) } & -0.02 & -0.02 & $0.31 *$ & $0.30^{*}$ & $-0.29 * * *$ & $-0.27 * *$ \\
\hline & $(0.13)$ & $(0.13)$ & $(0.17)$ & $(0.17)$ & $(0.10)$ & $(0.10)$ \\
\hline Observations & 642 & 642 & 671 & 671 & 641 & 641 \\
\hline Number of countries & 54 & 54 & 55 & 55 & 54 & 54 \\
\hline Adjusted R-squared & 0.306 & 0.319 & 0.304 & 0.326 & 0.153 & 0.158 \\
\hline Country fixed effects & YES & YES & YES & YES & YES & YES \\
\hline Time dummies & YES & YES & YES & YES & YES & YES \\
\hline
\end{tabular}

Sources: Chinn and Ito (2006), Google Trends, International Financial Statistics (IMF, 2018b), World Development Indicators (World Bank, 2018), World Economic Outlook (IMF, 2018e), and the authors' estimation.

Note. Sample period: 2004-2016. Cluster-robust standard errors are reported in parentheses. Superscripts *, **, and *** indicate statistical significance at the 10 percent, 5 percent, and 1 percent level, respectively. See Appendix Table 1 for country groupings and Appendix Table 3 for variable definitions (most of variables are in natural logarithm or percent change) and data sources. LIDCs: low-income developing countries; REER: real effective exchange rate; SVI: search volume index. 
Table 4. Capital flows and the search volume index (SVI) in LIDCs

\begin{tabular}{|c|c|c|c|c|c|c|c|c|}
\hline \multirow[b]{2}{*}{ Dependent variables } & (1) & (2) & (3) & (4) & $(5)$ & (6) & (7) & (8) \\
\hline & \multicolumn{2}{|c|}{$\begin{array}{c}\text { Total capital } \\
\text { inflows }\end{array}$} & \multicolumn{2}{|c|}{$\begin{array}{c}\text { Private capital } \\
\text { inflows }\end{array}$} & \multicolumn{2}{|c|}{ FDI inflows } & \multicolumn{2}{|c|}{ Non-FDI inflows } \\
\hline SVI: Finance & & $\begin{array}{l}-0.23 \\
(0.23)\end{array}$ & & $\begin{array}{l}-0.17 \\
(0.20)\end{array}$ & & $\begin{array}{l}-0.12 \\
(0.27)\end{array}$ & & $\begin{array}{l}-0.32 \\
(0.29)\end{array}$ \\
\hline SVI: Business and industrial & & $\begin{array}{c}1.19 * * * \\
(0.30)\end{array}$ & & $\begin{array}{c}0.94 * * * \\
(0.35)\end{array}$ & & $\begin{array}{l}1.24 * * \\
(0.53)\end{array}$ & & $\begin{array}{c}1.49 * * * \\
(0.50)\end{array}$ \\
\hline SVI: Law and government & & $\begin{array}{l}-0.22 \\
(0.32)\end{array}$ & & $\begin{array}{c}0.06 \\
(0.26)\end{array}$ & & $\begin{array}{l}-0.32 \\
(0.32)\end{array}$ & & $\begin{array}{l}-0.05 \\
(0.29)\end{array}$ \\
\hline SVI: Health & & $\begin{array}{l}-0.47 * * \\
(0.21)\end{array}$ & & $\begin{array}{l}-0.36 \\
(0.25)\end{array}$ & & $\begin{array}{l}-0.39^{*} \\
(0.22)\end{array}$ & & $\begin{array}{l}-0.19 \\
(0.21)\end{array}$ \\
\hline SVI: Travel & & $\begin{array}{l}-0.28 \\
(0.18) \\
\end{array}$ & & $\begin{array}{c}-0.58 * * * \\
(0.19) \\
\end{array}$ & & $\begin{array}{l}-0.21 \\
(0.24) \\
\end{array}$ & & $\begin{array}{c}-0.64^{* *} \\
(0.28) \\
\end{array}$ \\
\hline Lagged dependent variable & $\begin{array}{l}0.16^{* *} \\
(0.08)\end{array}$ & $\begin{array}{l}0.14^{*} \\
(0.08)\end{array}$ & $\begin{array}{c}0.08 \\
(0.10)\end{array}$ & $\begin{array}{c}0.06 \\
(0.09)\end{array}$ & $\begin{array}{c}0.23 * * * \\
(0.06)\end{array}$ & $\begin{array}{c}0.21^{* * * *} \\
(0.06)\end{array}$ & $\begin{array}{c}0.07 \\
(0.08)\end{array}$ & $\begin{array}{c}0.02 \\
(0.08)\end{array}$ \\
\hline Population (lag) & $\begin{array}{c}0.01 \\
(1.34)\end{array}$ & $\begin{array}{l}-1.00 \\
(1.39)\end{array}$ & $\begin{array}{l}-0.62 \\
(1.30)\end{array}$ & $\begin{array}{l}-2.22 * \\
(1.19)\end{array}$ & $\begin{array}{c}0.22 \\
(1.23)\end{array}$ & $\begin{array}{l}-0.01 \\
(1.30)\end{array}$ & $\begin{array}{c}0.78 \\
(1.52)\end{array}$ & $\begin{array}{l}-0.45 \\
(1.62)\end{array}$ \\
\hline Internet users (lag) & $\begin{array}{l}0.15^{*} \\
(0.08)\end{array}$ & $\begin{array}{c}0.10 \\
(0.09)\end{array}$ & $\begin{array}{l}0.19^{*} \\
(0.10)\end{array}$ & $\begin{array}{l}0.15 \\
(0.10)\end{array}$ & $\begin{array}{c}0.13 \\
(0.13)\end{array}$ & $\begin{array}{c}0.09 \\
(0.13)\end{array}$ & $\begin{array}{c}0.15 \\
(0.14)\end{array}$ & $\begin{array}{l}0.06 \\
(0.13)\end{array}$ \\
\hline Real GDP (lag) & $\begin{array}{c}0.47 \\
(0.63)\end{array}$ & $\begin{array}{c}0.56 \\
(0.62)\end{array}$ & $\begin{array}{l}1.04^{*} \\
(0.61)\end{array}$ & $\begin{array}{l}1.14^{*} \\
(0.59)\end{array}$ & $\begin{array}{c}0.96 \\
(0.90)\end{array}$ & $\begin{array}{c}0.94 \\
(0.86)\end{array}$ & $\begin{array}{l}-0.06 \\
(0.93)\end{array}$ & $\begin{array}{l}0.18 \\
(0.97)\end{array}$ \\
\hline Trade openness (lag) & $\begin{array}{l}0.55^{*} \\
(0.29)\end{array}$ & $\begin{array}{l}0.51^{*} \\
(0.26)\end{array}$ & $\begin{array}{l}0.68 * * \\
(0.29)\end{array}$ & $\begin{array}{c}0.67 * * \\
(0.26)\end{array}$ & $\begin{array}{l}0.55^{*} \\
(0.29)\end{array}$ & $\begin{array}{l}0.53^{*} \\
(0.30)\end{array}$ & $\begin{array}{c}1.27 * * * \\
(0.40)\end{array}$ & $\begin{array}{c}1.33^{* * * *} \\
(0.36)\end{array}$ \\
\hline Fiscal spending (lag) & $\begin{array}{c}0.26 \\
(0.24)\end{array}$ & $\begin{array}{c}0.26 \\
(0.26)\end{array}$ & $\begin{array}{c}0.30 \\
(0.23)\end{array}$ & $\begin{array}{c}0.33 \\
(0.22)\end{array}$ & $\begin{array}{c}0.11 \\
(0.26)\end{array}$ & $\begin{array}{c}0.07 \\
(0.27)\end{array}$ & $\begin{array}{l}-0.25 \\
(0.35)\end{array}$ & $\begin{array}{l}-0.31 \\
(0.37)\end{array}$ \\
\hline REER, log level (lag) & $\begin{array}{l}-0.15 \\
(0.40)\end{array}$ & $\begin{array}{l}-0.14 \\
(0.36)\end{array}$ & $\begin{array}{l}-0.13 \\
(0.41)\end{array}$ & $\begin{array}{l}-0.12 \\
(0.38)\end{array}$ & $\begin{array}{l}-0.05 \\
(0.39)\end{array}$ & $\begin{array}{c}0.06 \\
(0.36)\end{array}$ & $\begin{array}{c}0.04 \\
(0.69)\end{array}$ & $\begin{array}{l}0.16 \\
(0.68)\end{array}$ \\
\hline Inflation (lag) & $\begin{array}{l}-0.01 \\
(0.01)\end{array}$ & $\begin{array}{l}-0.01 \\
(0.01)\end{array}$ & $\begin{array}{l}-0.01 \\
(0.01)\end{array}$ & $\begin{array}{l}-0.01 \\
(0.01)\end{array}$ & $\begin{array}{l}-0.01 \\
(0.01)\end{array}$ & $\begin{array}{l}-0.01 \\
(0.01)\end{array}$ & $\begin{array}{l}-0.01 \\
(0.01)\end{array}$ & $\begin{array}{l}-0.01 \\
(0.01)\end{array}$ \\
\hline Trading partners' growth (lag) & $\begin{array}{c}0.05 \\
(0.04)\end{array}$ & $\begin{array}{c}0.05 \\
(0.04)\end{array}$ & $\begin{array}{c}0.05 \\
(0.04)\end{array}$ & $\begin{array}{c}0.05 \\
(0.04)\end{array}$ & $\begin{array}{c}0.04 \\
(0.03)\end{array}$ & $\begin{array}{c}0.04 \\
(0.03)\end{array}$ & $\begin{array}{l}-0.00 \\
(0.04)\end{array}$ & $\begin{array}{c}0.00 \\
(0.04)\end{array}$ \\
\hline Export price growth (lag) & $\begin{array}{c}0.01 \\
(0.02)\end{array}$ & $\begin{array}{c}0.01 \\
(0.02)\end{array}$ & $\begin{array}{l}-0.01 \\
(0.02)\end{array}$ & $\begin{array}{l}-0.00 \\
(0.01)\end{array}$ & $\begin{array}{c}0.01 \\
(0.01)\end{array}$ & $\begin{array}{c}0.01 \\
(0.01)\end{array}$ & $\begin{array}{c}-0.03^{* *} \\
(0.02)\end{array}$ & $\begin{array}{l}-0.02 \\
(0.02)\end{array}$ \\
\hline Capital account openness (lag) & $\begin{array}{c}0.11 \\
(0.52)\end{array}$ & $\begin{array}{c}0.02 \\
(0.59)\end{array}$ & $\begin{array}{c}0.45 \\
(0.42)\end{array}$ & $\begin{array}{c}0.55 \\
(0.44)\end{array}$ & $\begin{array}{l}-0.39 \\
(0.45)\end{array}$ & $\begin{array}{l}-0.54 \\
(0.44)\end{array}$ & $\begin{array}{c}1.73^{* * *} \\
(0.48)\end{array}$ & $\begin{array}{c}1.93 * * * \\
(0.45)\end{array}$ \\
\hline Age dependency ratio (lag) & $\begin{array}{c}0.00 \\
(0.02)\end{array}$ & $\begin{array}{c}0.01 \\
(0.02)\end{array}$ & $\begin{array}{c}0.00 \\
(0.02)\end{array}$ & $\begin{array}{c}0.00 \\
(0.02)\end{array}$ & $\begin{array}{l}-0.02 \\
(0.02)\end{array}$ & $\begin{array}{l}-0.02 \\
(0.02)\end{array}$ & $\begin{array}{l}-0.03 \\
(0.03)\end{array}$ & $\begin{array}{l}-0.03 \\
(0.03)\end{array}$ \\
\hline Observations & 461 & 461 & 454 & 454 & 535 & 535 & 377 & 377 \\
\hline Number of countries & 49 & 49 & 49 & 49 & 49 & 49 & 48 & 48 \\
\hline Adjusted R-squared & 0.424 & 0.437 & 0.419 & 0.433 & 0.339 & 0.348 & 0.390 & 0.414 \\
\hline Country fixed effects & YES & YES & YES & YES & YES & YES & YES & YES \\
\hline Time dummies & YES & YES & YES & YES & YES & YES & YES & YES \\
\hline
\end{tabular}

Sources: Chinn and Ito (2006), Google Trends, Financial Flows Analytics (IMF, 2018a), International Financial Statistics (IMF, 2018b), World Development Indicators (World Bank, 2018), World Economic Outlook (IMF, 2018e), and the authors' estimation.

Note. Sample period: 2004-2016. Cluster-robust standard errors are reported in parentheses. Superscripts *,**, and *** indicate statistical significance at the 10 percent, 5 percent, and 1 percent level, respectively. See Appendix Table 1 for country groupings and Appendix Table 3 for variable definitions (most of variables are in natural logarithm or percent change) and data sources. LIDCs: low-income developing countries; REER: real effective exchange rate; SVI: search volume index. 


\section{Comparison with nighttime lights}

Nighttime lights (NLs) extracted from processed satellite imagery can also serve as a nontraditional source of information for real-time economic monitoring, like SVIs.

Since the seminal application by Henderson, Storeygard, and Weil (2012), NLs have gained popularity as a proxy to the degree of economic activity (for a recent survey on the economic applications of satellite data, see Donaldson and Storeygard, 2016). While Henderson, Storeygard, and Weil (2012) compile annual data based on the Defense Meteorological Satellite Program Operational Linescan System (DMSP OLS) data, a newer data set based on the Visible Infrared Imaging Radiometer Suite (VIIRS) Day/Night Band (DNB) is available monthly since April 2012 (until October 2018 as of November 18, 2018), although its annual data set — with additional data cleaning — is available only for 2015 and 2016 at the time of writing. ${ }^{4}$ We use the annual data compiled by the R package Rnightlights, developed by Njuguna (2018), while cross-checking them with the data compiled by Henderson, Storeygard, and Weil (2012). The correlation between the two NL data are almost one (Appendix Table 5).

\section{We benchmark SVIs with NLs and find that SVIs may contain stronger signals on economic activity than NLs in LIDCs, while we find the opposite for EMEs. The significance of SVIs broadly remains while NLs are not statistically significant for LIDCs (Table 6, columns 1-4). For EMEs, however, the opposite is found-NLs are significant while SVIs are not (Table 6, columns 5-6). Further investigation indicates that the significance of NLs is lost for LIDCs when regressors include the lag of covariates (Appendix Table 6), whereas it is not lost for EMEs (Appendix Table 7). The contrasting results imply that there are some interesting structural differences between LIDCs and EMEs. For example, SVIs may better capture external factors, which may be relatively more important in LIDCs, whereas NLs may better reflect the level of domestic economic activity, which may play a larger role in EMEs than in LIDCs. The comparison between LIDCs and EMEs is also discussed in Section IV.D.}

\footnotetext{
${ }^{4}$ See https://ngdc.noaa.gov/eog/viirs/download_dnb_composites.html. Both original NL data sources are compiled by the initiatives under the National Oceanic and Atmospheric Administration (see the note under Table 6).
} 
Table 6. Search volume index (SVI) and nighttime lights (NLs)

\begin{tabular}{|c|c|c|c|c|c|c|}
\hline \multirow{4}{*}{ Dependent variables } & (1) & (2) & (3) & (4) & (5) & (6) \\
\hline & \multicolumn{6}{|c|}{ Real GDP } \\
\hline & \multicolumn{4}{|c|}{ LIDCs } & \multicolumn{2}{|c|}{ EMEs } \\
\hline & OLS & BMA & OLS & BMA & OLS & BMA \\
\hline \multirow[t]{2}{*}{ SVI: Finance } & 0.01 & 0.01 & 0.01 & 0.00 & 0.00 & 0.00 \\
\hline & $(0.02)$ & [0.39] & $(0.01)$ & {$[0.06]$} & $(0.01)$ & {$[0.08]$} \\
\hline \multirow[t]{2}{*}{ SVI: Business and industrial } & 0.02 & 0.00 & $0.06^{* * *}$ & 0.06 & -0.01 & -0.00 \\
\hline & $(0.03)$ & {$[0.14]$} & $(0.02)$ & {$[1.00]$} & $(0.01)$ & [0.13] \\
\hline \multirow[t]{2}{*}{ SVI: Law and government } & $-0.07 * * *$ & -0.07 & $-0.08 * * *$ & -0.08 & -0.00 & -0.00 \\
\hline & $(0.02)$ & {$[1.00]$} & $(0.02)$ & {$[1.00]$} & $(0.01)$ & {$[0.08]$} \\
\hline \multirow{2}{*}{ SVI: Health } & -0.01 & -0.00 & -0.01 & -0.00 & -0.02 & -0.01 \\
\hline & $(0.01)$ & {$[0.06]$} & $(0.02)$ & {$[0.00]$} & $(0.01)$ & {$[0.38]$} \\
\hline \multirow[t]{2}{*}{ SVI: Travel } & 0.02 & 0.00 & 0.00 & -0.00 & 0.01 & 0.00 \\
\hline & $(0.02)$ & {$[0.09]$} & $(0.02)$ & {$[0.05]$} & $(0.01)$ & {$[0.06]$} \\
\hline NLs from HSW (2012) & 0.01 & 0.00 & & & & \\
\hline \multirow{2}{*}{ NLs from HSW (2012) (lag) } & $(0.02)$ & $\begin{array}{l}{[0.00]} \\
-0.00\end{array}$ & & & & \\
\hline & $(0.01)$ & {$[0.06]$} & & & & \\
\hline \multirow[t]{2}{*}{ NLs from Rnightlights } & & & 0.01 & 0.00 & $0.02 * *$ & 0.02 \\
\hline & & & $(0.01)$ & {$[0.05]$} & $(0.01)$ & [0.94] \\
\hline \multirow[t]{2}{*}{ NLs from Rnightlights (lag) } & & & -0.01 & -0.00 & $-0.02 * *$ & -0.00 \\
\hline & & & $(0.01)$ & {$[0.09]$} & $(0.01)$ & {$[0.14]$} \\
\hline Control variables included & YES & YES & YES & YES & YES & YES \\
\hline Observations & 241 & 241 & 545 & 545 & 711 & 711 \\
\hline Sample period & 2004-2008 & 2004-2008 & 2004-2013, & 2004-2013, & 2004-2013, & 2004-2013, \\
\hline Number of countries & 53 & 53 & 53 & 53 & $\begin{array}{c}2015-2010 \\
70\end{array}$ & $\begin{array}{c}2015-2010 \\
70\end{array}$ \\
\hline Adjusted R-squared & 0.937 & - & 0.969 & - & 0.961 & - \\
\hline Country fixed effects & YES & YES & YES & YES & YES & YES \\
\hline Time dummies & YES & YES & YES & YES & YES & YES \\
\hline Excluding periods of jumps & NO & NO & NO & NO & NO & NO \\
\hline
\end{tabular}

Sources: Chinn and Ito (2006); Earth Observation Group; GADM (2018); Google Trends; Financial Flows Analytics (IMF, 2018a); Henderson, Storeygard, and Weil (2012); International Financial Statistics (IMF, 2018b); National Geophysical Data Center (with U.S. Air Force Weather Agency); World Development Indicators (World Bank, 2018); World Economic Outlook (IMF, 2018e); and the authors' estimation.

Note. For ordinary least squares (OLS), cluster-robust standard errors are reported in parentheses. Superscripts *, **, and *** indicate statistical significance at the 10 percent, 5 percent, and 1 percent level, respectively. For Bayesian model averaging (BMA), posterior inclusion probability (PIP) are reported in brackets. The coefficients are bolded if PIP exceeds 0.5 , corresponding to what is known as the median probability model (Barbieri and Berger, 2004). The estimation is implemented using the Stata command bma (De Luca and Magnus, 2011). The "NLs from HSW (2012)" line shows the coefficients on NL data (variable lndn) compiled by Henderson, Storeygard, and Weil (2012), available for 1992-2008. The "NLs from Rnightlights" line shows the coefficients on NL data compiled by the R package Rnightlights developed by Njuguna (2018), available for 1992-2013 based on DMSP OLS data (also used by Henderson, Storeygard, and Weil, 2012) and for 2015-2016 based on the Visible Infrared Imaging Radiometer Suite (VIIRS) Day/Night Band (DNB) data. The DMSP OLS data are based on the processed images provided by National Geophysical Data Center, while images are collected by U.S. Air Force Weather Agency. The VIIRS DNB data are produced by the Earth Observation Group, NOAA/NCEI. See Appendix Table 1 for country groupings and Appendix Table 3 for variable definitions (most of variables are in natural logarithm or percent change) and data sources. Among EMEs, the NL data exclude countries identified as outliers by Henderson, Storeygard, and Weil (2012, footnote 16, p. 1011; Bahrain, Equatorial Guinea, Serbia, Montenegro). For the data compiled by Rnightlights, several large economies are also excluded due to their heavy computational burden (Brazil, Chile, China, Indonesia, India, Mexico, Peru, Russia). DMSP OLS: Defense Meteorological Satellite Program Operational Linescan System; EMEs: emerging market economies; LIDCs: low-income developing countries; NCEI: National Centers for Environmental Information; NOAA: National Oceanic and Atmospheric Administration; REER: real effective exchange rate; SVI: search volume index. 


\section{Out-of-sample nowcasting}

We also examine out-of-sample performance of short-term forecasting (nowcasting). We conduct recursive forecasting using 2012 as the starting year and calculate the mean squared error (MSE) of prediction for 2013-2016. ${ }^{5}$ Namely, we predict the value of the variable of interest for 2013 by feeding observations available in 2013 (i.e., SVIs for 2013 and other variables for 2012) using the model estimated by the observations up to 2012 . We then repeat this to predict values for 2014, 2015, and 2016, incrementally using more data to estimate the model.

We compare the best predicting models selected from the pool of variables with and without SVIs. As including irrelevant variables to a model may increase the MSE, we conduct an exhaustive search from the pool of SVIs and control variables to identify the set of variables with which the linear regression model minimizes the MSE, combined with country fixed effects and time dummies. We then do this again only for control variables, without SVIs, and compare the MSEs between the two best predicting models. ${ }^{6}$

This way, we find that adding SVIs to the pool of variables improves performance in nowcasting economic indicators. We find that for all economic indicators to predict, the MSE of the best model is lower when including SVIs in the pool of selection, in the case of LIDCs (Table 7, Panel A). The differences in MSEs between the best models with and without SVIs are not very large in general nor statistically significant. Note that most of our comparisons are between nested models and the standard statistical inference based on the Diebold-Mariano test (Diebold and Mariano, 1995) across nested models may not be valid, especially in the presence of autocorrelation or cross-panel dependency (e.g., see Diebold, 2015, for the review of the literature). The SVIs included in the best model are generally in line with the in-sample analysis, but not always the same. For example, for real GDP, while the law-government SVI is always selected in the top 10 models in terms of the MSE, as is significant in the in-sample results, the business-industrial SVI is not selected, but instead, the finance SVI is selected (Appendix Table 8). Further investigation would be interesting to reconcile in-sample and out-of-sample results, as is actively discussed in the literature (e.g., Inoue and Kilian, 2005; Diebold, 2015, and associated comment papers).

\footnotetext{
${ }^{5}$ As our forecasting models include country fixed effects and time dummies, we follow Calhoun (2014) to set the prediction period to be close to the square root of the entire sample period $(4 \simeq \sqrt{13})$. The results may depend on the choice of the starting year in general (Rossi and Inoue, 2012).

${ }^{6}$ We also compare the averages of the lowest 10 MSEs, instead of only the lowest MSE, and find very similar results.
} 
Table 7. Out-of-sample performance of nowcasting

\begin{tabular}{|c|c|c|c|c|c|}
\hline $\begin{array}{l}\text { Real } \\
\text { GDP }\end{array}$ & $\begin{array}{c}\text { Real } \\
\text { exports }\end{array}$ & $\begin{array}{l}\text { Tourist } \\
\text { arrivals }\end{array}$ & Inflation & $\begin{array}{c}\text { Nominal } \\
\text { exchange } \\
\text { rate }\end{array}$ & $\begin{array}{c}\text { Private } \\
\text { capital } \\
\text { inflows }\end{array}$ \\
\hline
\end{tabular}

Panel A. MSE of the best model with fixed and time effects - LIDCs

$\begin{array}{lccccccc}\text { Controls only } & 0.37 & 1.60 & 7.58 & 0.12 & 0.83 & 60.84 & 122.40 \\ \text { Controls + SVIs } & 0.36 & 1.59 & 6.89 & 0.11 & 0.73 & 55.96 & 117.68 \\ \text { Difference (in percent) } & \mathbf{- 2 . 6} & \mathbf{- 1 . 0} & \mathbf{- 1 0 . 0} & \mathbf{- 7 . 4} & \mathbf{- 1 4 . 4} * * * & \mathbf{- 8 . 7} * * * & \mathbf{- 4 . 0}\end{array}$

Panel B. MSE of the best model with fixed and time effects - EMEs

$\begin{array}{lccccccc}\text { Controls only } & 0.09 & 0.77 & 1.92 & 0.45 & 1.00 & 75.45 & 47.90 \\ \text { Controls + SVIs } & 0.08 & 0.76 & 1.92 & 0.44 & 0.95 & 75.22 & 47.90 \\ \text { Difference (in percent) } & \mathbf{- 3 . 1} & \mathbf{- 1 . 4} & \mathbf{0 . 0} & \mathbf{- 2 . 0} & \mathbf{- 5 . 5 * * *} & \mathbf{- 0 . 3} & \mathbf{0 . 0}\end{array}$

Sources: Chinn and Ito (2006), Google Trends, Financial Flows Analytics (IMF, 2018a), International Financial Statistics (IMF, 2018b), World Development Indicators (World Bank, 2018), World Economic Outlook (IMF, 2018e), and the authors' estimation.

Note: We conduct recursive forecasting using a panel data set from 2004 to 2016 . We set 2012 as the starting year and calculate the mean squared error (MSE) of prediction for 2013-2016. We predict the value of the variable of interest for 2013, by feeding observations available in 2013 (i.e., SVIs for 2013 and other controls for 2012) using the model estimated by the observations up to 2012. We then repeat this to predict values for 2014, 2015, and 2016, incrementally using more data to estimate the model. We include country fixed effects and time dummies, from which we back out the averaged constant term so that country fixed effects and time effects are redefined as deviations from the constant term, and thus, ex ante time effects for prediction years can be assumed to be zero. Panel A shows the results for LIDCs and Panel B shows the results for EMEs. The "Control variables + SVIs" lines show the minimum MSEs identified by an exhaustive search from the pool of all variables to be included in the model. The "Controls only" lines show the minimum MSEs identified by an exhaustive search from the pool of control variables, excluding the SVIs. See Appendix Tables 8 and 9 for the best model specifications chosen in this procedure. To overcome a computational challenge stemming from the exhaustive search across variables to include, we follow the algorithm proposed by Somaini and Wolak (2016) to speed up the calculation to estimate regressions with two-way fixed effects. The "Difference (in percent)" lines show the differences of the above two lines in percent of the second line. Superscripts $* * *$, and $* * *$ indicate statistical significance at the 10 percent, 5 percent, and 1 percent level, respectively, based on a Diebold-Mariano test (Diebold and Mariano, 1995) using cluster-robust standard errors, although it should be noted that most of these model comparisons are between nested models and conducting statistical inference across nested models is not trivial, especially when forecasting errors could exhibit autocorrelation or cross-panel dependency (e.g., see Diebold, 2015, for a review of the literature). The nominal exchange rate is the local currency per U.S. dollar, transformed to annual percent changes, period average. See Appendix Table 1 for country groupings and Appendix Table 3 for variable definitions (most of variables are in natural logarithm or percent change) and data sources. For inflation and nominal exchange rate, we divide them by 100 to be comparable to other logged variables for this table. EMEs: emerging market economies; LIDCs: low-income developing countries; SVI: search volume index. 


\section{EXTENSIONS}

\section{A. Jumps in the SVIs}

We observe jumps (or positive outliers) in SVIs occasionally. These acute increases in the SVIs are associated with critical events, including natural disasters, major policy changes, and key developments in the business environment. We identify 178 jumps in the SVI for the "all" category (i.e., with no category specified) out of 804 observations in our sample for LIDCs, using a methodology in the finance literature (Lee and Mykland, 2008). The difference between the squared percent change and the consecutive absolute percent change (called bi-power variations) indicates a huge change in the SVI within a period (see Appendix I, Section E for details). The reason for not using each SVI by category for the jump detection is to focus on very acute increases in individuals' attention that are significant enough to stand out in the SVI with no category specified, even though their causes would be category-specific.

Excluding the periods when a jump occurred seems to sharpen estimation results. As each jump would have a very different implication from one another, we exclude those periods with jumps from the sample and re-estimate our models. The results show more statistical significance in many cases, while there is no significant change for inflation and the significance rather weakens for real exports and FDI inflows (Appendix Table 10). This implies that jumps in SVIs could indicate the periods when their relationships with economic variables become unstable or strongly nonlinear, and that excluding such periods either strengthens the true linear relationships or weakens the spurious significance.

\section{B. Lagged effects}

There could be time lags for people's attentions to materialize as actual economic actions. Search of background information would happen before travel or investment take place. In this regard, SVIs could rather serve as a leading indicator.

In our specifications, lagged SVIs do not show significant correlation as clearly as contemporaneous SVIs do (Appendix Table 11). This is probably because our models are at the annual frequency and the one-year lag could be too long. An exception is the case of private capital flows where lagged SVIs work better. For real GDP, lagged SVIs seem to complement contemporaneous SVIs. More meaningful leading signals could possibly be found in the SVIs at a higher frequency such as monthly, although limited availability of other indicators at a higher frequency would pose a challenge for such an analysis.

\section{Searches made domestically}

We further examine SVIs on the searches made domestically. We construct an additional data set of SVIs by changing the location from "worldwide" to each country of interest—e.g., searches about Bangladesh made in Bangladesh. We refer to these SVIs as domestic SVIs. The domestic SVIs would capture individuals' attention to a country in that country. The domestic SVIs are more likely to be subject to the issue of low responses and the reporting cut-off, but they would potentially capture certain activities (especially those that happened locally) better than the worldwide SVIs. 
Including domestic SVIs do not generally change the regression results, implying that the major source of information from worldwide SVIs is attention from foreign

locations. Results do not change for most of the cases, except capital flows, which now show weaker correlation (Appendix Table 12). The domestic business-industrial SVI is negatively associated with inflation, which may reflect the importance of inflation for local businesses.

\section{Does it work for EMEs too?}

We also investigate whether Google's SVIs would be useful for macroeconomic analyses in EMEs. Our work can naturally extend to EMEs, many of which share common characteristics with LIDCs (see Appendix Table 1 for the list of the EMEs and Appendix Table 13 for summary statistics for EMEs).

For EMEs, the correlations between SVIs and macroeconomic variables are not as robust as those for LIDCs (Appendix Table 14). As discussed in Section III.C, the weaker correlations might imply relatively weaker influences of the external factors to EMEs than LIDCs - due to larger domestic markets in EMEs - because SVIs may better capture external factors related to online searches from abroad. Another reason could be that investors' behaviors to gain information about EMEs through the Internet may not be significant signals among other key factors in more matured and complicated financial markets in EMEs than those in LIDCs. Similarly, adding SVIs does not improve the nowcasting accuracy for EMEs as much as it does for LIDCs (Table 7, Panel B; Appendix Table 9).

\section{Conclusion}

This paper presents an effort to use advanced technology to address the recurrent issue of lack of information in policy-making and analysis for developing economies. While progress has been made in timely provision of official data, nontraditional data obtained through recent technology have enormous potential to fill information gaps in developing economies. We investigate how much information we could obtain from Internet search frequencies to strengthen the capacity to monitor and assess current economic developments.

Our findings help us better utilize new sources of information such as Google Trends' data in economic analyses. Useful information contained in Google's SVI is demonstrated by the improved in-sample and out-of-sample performances of a simple forecasting model, conditional on lagged macroeconomic variables. The contrasting results between LIDCs and EMEs regarding the comparison of SVIs and another new source of information - nighttime lights - not only demonstrate the stronger case for the use of SVIs for LIDCs but also suggest the need to further investigate any structural differences between these country groups. The estimated regression models indicate whether positive or negative effects are to be expected for each SVI and provide quantitative implications from the changes in SVIs. The results also indicate that jumps or outliers in SVIs may need to be separately treated because the estimated linear relationships are likely to break on these occasions. Monitoring SVIs can complement the use of judgement required in making forecasts, particularly for low-income countries where statistical models are generally less reliable than advanced economies due to data availability (Independent Evaluation Office, 2014, paragraph 34, p. 13). 
There are several lessons learned about the use of Google Trends' data in economic analyses. First, monitoring SVIs under several categories is recommended to separate positive and negative signals. Second, interpreting jumps in SVIs warrants caution as they may likely indicate a departure from the normal relationships. What causes a jump can be identified by typing the country name and the period when a jump occurred into an online search engine. Lastly, a more granular analysis using specific search terms would be attractive but indeed challenging. This is not only because such an analysis would highly depend on the choice of terms (e.g., see a discussion by Smith, 2016, cited by Harchaoui and Janssen, 2018), but also because using more than one search term often leads to very low frequencies and sometimes falls below a threshold to be cut off, resulting in a zero response. For this reason, we use Google's Knowledge Graph service to identify a topic rather than a term and keep our topic as broad as a country, while achieving granularity by using SVIs under various categories. These practical solutions, however, rely on nontransparent methodologies and could undermine the credibility of the analyses.

There is still more to be explored to fully realize the potential benefits of using Google's SVIs. Our results at the annual frequency makes the case for more practical analyses on the use of Google's SVIs in constructing high frequency indicators of economic activities, as SVIs are available monthly (or even weekly for past 5 years, via the web service). In practice, nowcasting models may need to be tailored to the country of applications for more accuracy. Taking care of jumps in SVIs would be more important in such analyses, as these jumps can be noise or may serve as forewarning for a surge or a decline in the economy. Lastly, more flexible methodologies to analyze data, such as machine learning techniques discussed by Varian (2014) and Mullainathan and Spiess (2017), could help extract more useful information from the SVIs.

The use of SVIs to cross-check the validity of official statistics would be interesting, but we need to be cautious. As is the case for nighttime lights (Henderson, Storeygard, and Weil, 2012), the SVIs may possibly be used to cross-check the validity of official statistics, particularly in the context of a large share of the informal economy in LIDCs and other developing economies. If official statistics (e.g., real GDP) appeared much lower than the levels implied by observed SVIs, then it might indicate that a sizable portion of economic activities might not be captured by official statistics. This is the same logic behind the sociological literature on measuring issue salience (e.g., Stephens-Davidowitz, 2017). We need to be cautious, however, because a deviation between SVIs and official statistics would not necessarily be a proof of inaccuracy in the official statistics. Other factors include noises in SVIs themselves, unannounced changes in measurement of SVIs, and structural breaks in the relationships between SVIs and economic activities. Reis, Ferreira, and Perduca (2014, section 6) list the challenges in using Google's SVIs in compiling official statistics, including transparency, auditability, consistency in measurement over time, and continuity of the Google Trends service in the future.

Further research is also needed for a more systematic use of Google's SVIs in policy decision making. Although the frequency of online search per se should be as objective as transaction data - unlike qualitative indicators based on subjective judgements - , it is still influenced by uncertainties stemming from the natural language processing algorithm used to compile category-specific SVIs (whose details are not disclosed to the public) and from Google's Knowledge Graph service that may not perfectly distinguish topics very close to 
each other (e.g., the Republic of the Congo versus the Democratic Republic of the Congo). The objectivity of Google's SVIs can be examined by comparing them with survey data (Vosen and Schmidt, 2011). In addition, while we provide certain conditions in Appendix I, Section D where the SVI could represent people's attention without bias, the SVI may send a biased signal if these conditions do not hold. Lastly, as is known as Campbell's law (Campbell, 1979), a predominant use of Google's SVIs in policy decision making could provide undesirable incentives to manipulate frequencies of particular search termsmanually or automatically using Internet bots-, distorting the useful relationships between SVIs and macroeconomic data. Addressing these concerns and caveats is left for future research.

\section{REFERENCES}

Acevedo, Sebastian, 2016, "Nowcasting GDP with Google Trends," Proof of Concept for the IMF's Big Data Challenge, Unpublished.

Adachi, Yuta, Motoki Masuda, and Fumiko Takeda, 2017, "Google search intensity and its relationship to the returns and liquidity of Japanese startup stocks," Pacific-Basin Finance Journal, 46, 243-257.

Afkhami, Mohamad, Lindsey Cormack, and Hamed Ghoddusia, 2017, "Google search keywords that best predict energy price volatility," Energy Economics, 67, 17-27.

Aouadi, Amal, Mohamed Arouri, and Frédéric Teulon, 2013, "Investor attention and stock market activity: Evidence from France," Economic Modelling, 35, 674-681.

Araujo, Juliana D., Antonio C. David, Carlos van Hombeeck, and Chris Papageorgiou, 2017, "Joining the club? Procyclicality of private capital inflows in lower income developing economies," Journal of International Money and Finance, 70, 157-182. http://dx.doi.org/10.1016/j.jimonfin.2016.08.006

Artola, Concha, Fernando Pinto, and Pablo de Pedraza García, 2015, "Can internet searches forecast tourism inflows?” International Journal of Manpower, 36:1, 103-116. https://doi.org/10.1108/IJM-12-2014-0259

Askitas, Nikolaos, and Klaus F. Zimmermann, K. F., 2009, “Google Econometrics and Unemployment Forecasting,” DIW Berlin Discussion Paper No. 899.

Bangwayo-Skeete, Prosper F., and Ryan W. Skeete, 2015, "Can Google data improve the forecasting performance of tourist arrivals? Mixed-data sampling approach," Tourism Management, 46(C): 454-464.

Barbieri, Maria M., and James O. Berger, 2004, "Optimal Predictive Model Selection," Annals of Statistics, 32:3, 879-897. DOI 10.1214/009053604000000238

Barreira, Nuno, Pedro Godinho, and Paulo Melo, 2013, "Nowcasting unemployment rate and new car sales in south-western Europe with Google Trends," Netnomics, 14:129165. DOI:10.1007/s11066-013-9082-8 
Barro, Robert J., 2015, “Convergence and modernization,” The Economic Journal 125 (585): 911-942. https://doi.org/10.1111/ecoj.12247

Buono, Dario, Gian Luigi Mazzi, George Kapetanios, Massimiliano Marcellino, and Fotis Papailias, 2017, "Big data types for macroeconomic nowcasting," Eurostat Review on National Accounts and Macroeconomic Indicators, 1/2017, 93-145.

Calhoun, Gray, 2014, "Out-of-sample comparisons of overfit models," Economics Working Papers, No. 11002. Iowa State University.

Campbell, Donald T., 1979, "Assessing the impact of planned social change," Evaluation and Program Planning, 2 (1): 67-90. DOI:10.1016/0149-7189(79)90048-X.

Campos, I., G. Cortazar, and T. Reyes, 2017, “Modeling and predicting oil VIX: Internet search volume versus traditional variables," Energy Economics, 66, 194-204.

Carrière-Swallow, Yan, and Felipe Labbé, 2013, "Nowcasting with Google Trends in an Emerging Market," Journal of Forecasting, 32 (4): 289-298.

Chadwick, Meltem Gülenay, and Gönül Şengül, 2015, "Nowcasting the unemployment rate in Turkey: Let's ask Google," Central Bank Review, 15, 15-40.

Chamberlin, Graeme, 2010, "Googling the present," Economic and Labour Market Review, 4:12, 59-95.

Chinn, Menzie D., and Hiro Ito, 2006, "What matters for financial development? capital controls, institutions, and interactions," Journal of Development Economics, 81:1, 163-192. https://web.pdx.edu/ ito/Chinn-Ito website.htm

Choi, Hyunyoung, and Hal R. Varian, 2012, "Predicting the present with google trends," Economic Record, 88, 2-9.

Choi, Sangyup, and Yuko Hashimoto, 2018, "Does transparency pay? Evidence from IMF data transparency policy reforms and emerging market sovereign bond spreads," Journal of International Money and Finance, 88, 171-190.

Da, Zhi, Joseph Engelberg, and Pengjie Gao, 2011, "In Search of Attention," Journal of Finance, 66 (5): 1461-1499. ,2015, "The sum of all FEARS investor sentiment and asset prices," Review of Financial Studies, 28:1, 1-32. https://doi.org/10.1093/rfs/hhu072

D’Amuri, Francesco, and Juri Marcucci, 2017, “The predictive power of Google searches in forecasting US unemployment," International Journal of Forecasting, 33, 801-816.

De Luca, Giuseppe, and Jan R. Magnus, 2011, "Bayesian model averaging and weightedaverage least squares: equivariance, stability, and numerical issues," Stata Journal, $11: 4,18-544$. 
Diebold, Francis X., 2015, “Comparing predictive accuracy, twenty years later: a personal perspective on the use and abuse of Diebold-Mariano tests," Journal of Business and Economic Statistics, 33:1, 1-9. DOI: 10.1080/07350015.2014.983236

, and Roberto S. Mariano, 1995, “Comparing Predictive Accuracy,” Journal of Business and Economic Statistics, 13:3, 253-263. DOI:

10.1080/07350015.1995.10524599

Dimpfl, Thomas, and Stephan Jank, 2016, “Can Internet search queries help to predict stock market volatility?” European Financial Management, 22:2, 171-192. https://doi.org/10.1111/eufm.12058

Donalodson, Dave, and Adam Storeygard, 2016, "The view from above: applications of satellite data in economics," Journal of Economic Perspectives, 30:4, 171-198.

Engstrom, Ryan, Jonathan Hersh, and David Newhouse, 2017, "Poverty from space: using high-resolution satellite imagery for estimating economic well-being," Policy Research Working Paper, Washington: World Bank.

Ferreira, Pedro. 2014, "Improving Prediction of Unemployment Statistics with Google Trends: Part 2," Eurostat Working Paper.

Fondeur, Y., and Karamé, Y, 2013, “Can Google data help predict French youth unemployment?" Economic Modelling, 30, 117-125. https://doi.org/10.1016/j.econmod.2012.07.017

GADM, 2018, Database of Global Administrative Areas, https://gadm.org/, accessed in September 2018.

Ginsberg, Jeremy, Matthew H. Mohebbi, Rajan S. Patel, Lynnette Brammer, Mark S Smolinski, and, Larry Brilliant. 2009, "Detecting influenza epidemics using search engine query data," Nature, 457:7232, 1012-1014.

Goddard, John, Arben Kita, and Qingwei Wang, 2015, "Investor attention and FX market volatility," Journal of International Financial Markets, Institutions and Money, 38, 79-96.

Götz, Thomas B., and Thomas A. Knetsch, 2019 "Google data in bridge equation models for German GDP," International Journal of Forecasting, 35, 45-66.

Hamid, A., and Heiden, M., 2015, "Forecasting Volatility with Empirical Similarity and Google Trends," Journal of Economic Behavior and Organization, 117, 62-81.

Hammer, Cornelia L., Diane C. Kostroch, Gabriel Quirós, and STA Internal Group, 2017, "Big data: potential, challenges, and statistical implications," IMF Staff Discussion Note, Washington: International Monetary Fund. 
Harchaoui, Tarek M., and Robert V. Janssen, 2018, "How can big data enhance the timeliness of official statistics?: The case of the US consumer price index," International Journal of Forecasting, 34:2, 225-234.

Hashimoto, Yuko, and K. M. Wacker, 2016, "The role of information for international capital flows: new evidence from the SDDS," Review of World Economics, 152:3, 529-557. DOI: 10.1007/s10290-016-0250-4

Henderson, Vernon, J., Adam Storeygard, and David N. Weil, 2012, "Measuring economic growth from outer space," American Economic Review, 102:2, 994-1028. https://doi.org/10.1257/aer.102.2.994

Independent Evaluation Office, 2014, "IMF forecasts: process, quality, and country perspectives," Evaluation Report, Washington: International Monetary Fund.

Independent Evaluation Office, 2016, "Behind the scenes with data at the IMF: an IEO evaluation,” Evaluation Report, Washington: International Monetary Fund.

Inoue, Atsushi, and Lutz Kilian, 2005, "In-sample or out-of-sample tests of predictability: which one should we use?" Econometric Reviews, 23:4, 371-402. DOI: 10.1081/ETC-200040785

International Monetary Fund, 2015a, "Macroeconomic developments in low-income developing countries," Policy Paper, Washington: International Monetary Fund. , 2015b, "Myanmar: 2015 Article IV Consultation Staff Report," Country Report No. 15/267, Washington: International Monetary Fund.

, 2015c, "Samoa: 2015 Article IV Consultation Staff Report," Country Report No. 15/191, Washington: International Monetary Fund.

, 2018a, Financial Flows Analytics, confidential and internally accessed in November 2018, Washington: International Monetary Fund.

, 2018b, International Financial Statistics, http://data.imf.org/?sk=4C514D48B6BA-49ED-8AB9-52B0C1A0179B, accessed in November 2018, Washington: International Monetary Fund.

,2018c, "Macroeconomic developments in low-income developing countries2018," Policy Paper, March, Washington: International Monetary Fund.

,2018d, "Overarching strategy on data and statistics at the fund in the digital age," Policy Paper, March, Washington: International Monetary Fund.

,2018e, Statistical Appendix of the October 2018 World Economic Outlook, Washington: International Monetary Fund. 
Jean, Neal, Marshall Burke, Michael Xie, W. Matthew Davis, David B. Lobell and Stefano Ermon, 2016, "Combining satellite imagery and machine learning to predict poverty," Science, 353:6301, 790-794. DOI: 10.1126/science.aaf7894

Joseph, Kissan, M. Babajide Wintoki, and Zelin Zhang, 2011, "Forecasting abnormal stock returns and trading volume using investor sentiment: Evidence from online search," International Journal of Forecasting, 27, 1116-1127.

Kleinberg, Jon, Jens Ludwig, Sendhil Mullainathan, and Ziad Obermeyer, 2015, "Prediction Policy Problems," American Economic Review, 105:5, 491-495. http://dx.doi.org/10.1257/aer.p20151023

Koop, Gary, and Luca Onorante, 2013, "Macroeconomic Nowcasting Using Google Probabilities," retrieved at: https://www.ecb.europa.eu/events/pdf/conferences/140407/OnoranteKoop_Macroec onomicNowcastingUsingGoogleProbabilities.pdf.

Laframboise, Nicole, Nkunde Mwase, Joonkyu Park, and Yingke Zhou, 2014, "Revisiting tourism flows to the Caribbean: what is driving arrivals?" IMF Working Paper 14/229, Washington: International Monetary Fund.

Lampos, Vasileios, Andrew C. Miller, Steve Crossan, and Christian Stefansen, 2015, "Advances in nowcasting influenza-like illness rates using search query logs," Scientific Reports, 5:12760. DOI: 10.1038/srep12760

Leamer, Edward E., 1978, Specification Search: Ad Hoc Inference with Nonexperimental Data, New York: Wiley.

Lee, Suzanne S., and Per A. Mykland, 2008, “Jumps in financial markets: a new nonparametric test and jump dynamics," Review of Financial Study, 21:6, 25352563. https://doi.org/10.1093/rfs/hhm056

Li, Xin, Wei Shang, Shouyang Wang, and Jian Ma, 2015, “A MIDAS modelling framework for Chinese inflation index forecast incorporating Google search data," Electronic Commerce Research and Applications, 14:2, 112-125. https://doi.org/10.1016/j.elerap.2015.01.001

Li, Xin, Jian Ma, Shouyang Wang, and Xun Zhang, 2015, "How does Google search affect trader positions and crude oil prices?” Economic Modelling, 49, 162-171.

Li, Xin, Bing Pan, Rob Law, and Xiankai Huang, 2017, "Forecasting tourism demand with composite search index," Tourism Management, 59, 57-66.

Moussa, Faten, Ezzeddine Delhoumi, and Olfa Ben Ouda, 2017, "Stock return and volatility reactions to information demand and supply," Research in International Business and Finance, 39, 54-67.

Mullainathan, Sendhil, and Jann Spiess, 2017, "Machine learning: an applied econometric approach," Journal of Economic Perspectives, 31:2, 87-106. 
Njuguna, Christopher, 2018, "Rnightlights: Satellite Nightlight Data Extraction," Comprehensive R Archive Network, https://cran.rproject.org/web/packages/Rnightlights/index.html (for a developer version, https://github.com/chrisvwn/Rnightlights, accessed in September 2018).

Peltomäki, Jarkko, Michael Graham, and Anton Hasselgren, 2018, "Investor attention to market categories and market volatility: The case of emerging markets," Research in International Business and Finance, 44, 532-546. http://dx.doi.org/10.1016/j.ribaf.2017.07.124

Preis, Tobias, Helen Susannah Moat, and H. Eugene Stanley, 2013, “Quantifying Trading Behavior in Financial Markets Using Google Trends," Scientific Reports, 3:1684.

Reis, Fernando, Pedro Ferreira, and Vittorio Perduca, 2014, "The use of web activity evidence to increase the timeliness of official statistics indicators," Eurostat Working Paper.

Rivera, Roberto, 2016, "A dynamic linear model to forecast hotel registrations in Puerto Rico using Google Trends data," Tourism Management, 57, 12-20.

Ross, Andrew, 2013, "Nowcasting with Google Trends: a keyword selection method," Fraser of Allander Economic Commentary, 37:2, 54-64.

Rossi, Barbara, and Atsushi Inoue, 2012, "Out-of-sample forecast tests robust to the choice of window size," Journal of Business and Economic Statistics, 30:3, 432-453.

Scott, Steven L., and Hal R. Varian, 2015, "Bayesian variable selection for nowcasting economic time series," Chapter 4, 119-135, in Economic Analysis of the Digital Economy, edited. by Avi Goldfarb, Shane M. Greenstein, and Catherine E. Tucker, Illinois: University of Chicago Press.

Siliverstovs, Boriss, and Daniel S. Wochner, 2018, "Google Trends and reality: Do the proportions match? Appraising the informational value of online search behavior: Evidence from Swiss tourism regions," Journal of Economic Behavior and Organization, 145 (C): 1-23.

Smith, Geoffrey Peter, 2012, "Google Internet search activity and volatility prediction in the market for foreign currency," Finance Research Letters, 9, 103-110.

Smith, Paul, 2016, "Google's MIDAS Touch: Predicting UK Unemployment with Internet Search Data," Journal of Forecasting, 35:3, 263-284.

Somaini, Paulo, and Frank Wolak, 2016, "An Algorithm to Estimate the Two-Way Fixed Effects Model," Journal of Econometric Methods, 5:1, 143-152. https://doi.org/10.1515/jem-2014-0008

StatCounter, 2018, Global Stats. http://gs.statcounter.com/search-engine-market-share, accessed in July 2018. 
Stephens-Davidowitz, Seth, 2017, Everybody lies: big data, new data, and what the Internet can tell us about who we really are, New York: HarperCollins Publishers.

, and Hal R. Varian, 2015, "A Hands-on Guide to Google Data," retrieved at http://people.ischool.berkeley.edu/ hal/Papers/2015/primer.pdf, Google.

Takeda, Fumiko, and Takumi Wakao, 2014, "Goggle search intensity and its relationship with returns and trading volume of Japanese stocks," Pacific-Basin Finance Journal, 27, 1-18.

Tang, Wenbin, and Lili Zhu, 2017, "How security prices respond to a surge in investor attention: Evidence from Google Search of ADRs", Global Finance Journal, 33, 38-50.

Tantaopas, Parkpoom, Chaiyuth Padungsaksawasdi, and Sirimon Treepongkaruna, 2016, "Attention effect via internet search intensity in Asia-Pacific stock markets," Pacific-Basin Finance Journal, 38, 107-124.

Thomas, Evan, Luis Alberto Andrés, Christian Borja-Vega, and Germán Sturzenegger, eds., 2018, "Innovations in WASH impact measures: water and sanitation measurement technologies and practices to inform the Sustainable Development Goals," Directions in Development, Washington: World Bank. doi:10.1596/978-1-46481197-5. License: Creative Commons Attribution CC BY 3.0 IGO.

United Nations Economic Commission for Europe, 2013, "Classification of types of big data." https://statswiki.unece.org/display/bigdata/Classification+of+Types+of+Big+Data

Varian, Hal R., 2014, "Big data: new tricks for econometrics," Journal of Economic Perspectives, 31:2, 87-106.

Vicente, María Rosalía, Ana J. López-Menéndez, and Rigoberto Pérez, 2015, "Forecasting unemployment with internet search data: Does it help to improve predictions when job destruction is skyrocketing?" Technological Forecasting and Social Change, 92, 132-139.

Vlastakis, Nikolaos, and Raphael N. Markellos, 2012, "Information demand and stock market volatility," Journal of Banking and Finance, 36, 1808-1821.

Vosen, Simeon, and Torsten Shmidt, 2011, "Forecasting private consumption: survey-based indicators vs. Google Trends,” Journal of Forecasting, 30, 565-578.

Vozlyublennaia, Nadia, 2014, "Investor attention, index performance, and return predictability," Journal of Banking and Finance, 41, 17-35. http://dx.doi.org/10.1016/j.jbankfin.2013.12.010

Welagedara, Venura, Saikat Sovan Deb, and Harminder Singh, 2017, "Investor attention, analyst recommendation revisions, and stock prices," Pacific-Basin Finance Journal, 45, 211-223. 
Wesolowski, Amy, Nathan Eagle, Andrew J. Tatem, David L. Smith, Abdisalan M. Noor, Robert W. Snow, and Caroline O. Buckee, 2012, "Quantifying the impact of human mobility on malaria," Science, 338:6104, 267-270. doi: 10.1126/science.1223467

World Bank, 2018, World Development Indicator, https://datacatalog.worldbank.org/dataset/world-development-indicators, accessed in November 2018, Washington: World Bank.

Wu, Lynn, and Erik Brynjolfsson, 2015, "The future of prediction: how Google searches foreshadow housing prices and sales," Chapter 3, 89-118, in Economic Analysis of the Digital Economy, edited. by Avi Goldfarb, Shane M. Greenstein, and Catherine E. Tucker, Illinois: University of Chicago Press.

Yang, Xin, Bing Pan, James A. Evans, and Benfu Lv, 2015, "Forecasting Chinese tourist volume with search engine data," Tourism Management, 46, 386-397.

Yung, Kenneth, and Nadia Nafar, 2017, "Investor attention and the expected returns of REITs," International Review of Economics and Finance, 48, 423-439. 


\section{APPENDIX I. TECHNICAL DETAILS}

\section{A. Introduction to Google's Search Volume Index (SVI)}

The Google Trends service compiles an index, SVI, which measures how many times a keyword (or key words under a topic) has been submitted to the Google search engine. A search topic, rather than just a keyword, can be specified to deal with ambiguity of a search word due to homographs. Appendix Figure 1 shows an example of the SVI of search queries on country "Kenya" as a topic, from all over the world (specified as "Worldwide"), classified as the finance category (specified as "Finance"). Data points A and B are first calculated as the ratios of searches related to topic "Kenya," divided by the total searches for all queries from the same location ("Worldwide"), under the same category ("Finance"), for each period (October 2011 and July 2015, respectively). In this case, point B is the maximum of such ratios over time, and therefore, the SVI for July 2015 shows 100 and the SVI for October 2011 shows 58, which is computed as the ratio of A to B multiplied by 100 .

\section{Appendix Figure 1. Google Trends search for "Kenya" as a search topic}

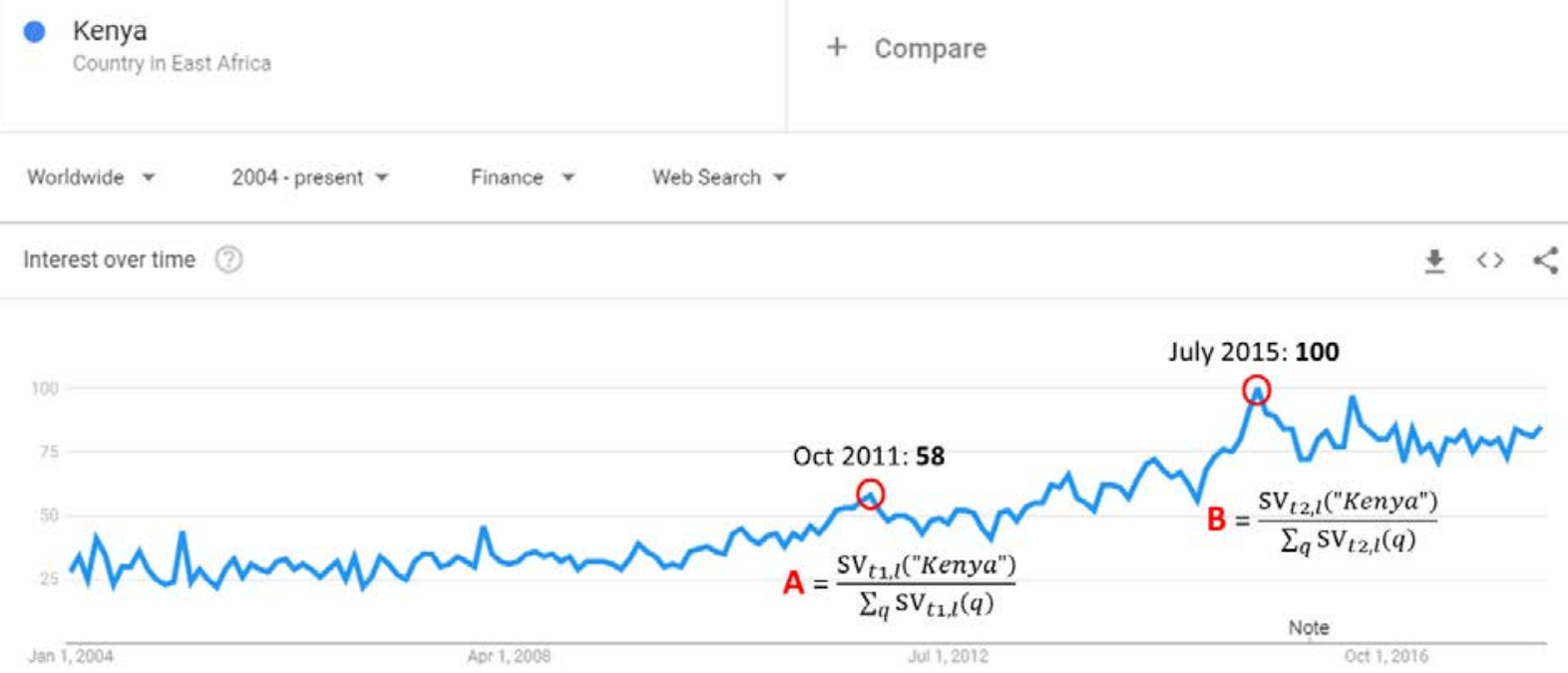

Source: Google Trends' website (https://trends.google.com/trends/).

The SVI is constructed from sub-samples of total search data, randomly selected periodically to take a balance between usefulness and anonymity. Although all the queries submitted are stored, the Google Trends service conducts a random sampling and uses only a fraction of the entire search data to construct an SVI. Too small observations are also concealed. Re-sampling is done periodically (e.g., daily), which complicates the replication of the data downloaded previously. It is then recommended that researchers repeat downloading the same data to take the average and focus on inferred population moments, while it is also reported that the sampling generally gives reasonably precise estimates, and more than a single sample may not be needed in practice (Stephens-Davidowitz and Varian, 2015).

We retrieve monthly SVIs via Google Trends' Application Programming Interface (API), which has two major differences from the website. The SVI from the API is 
compiled from a 10-percent sample of total Google searches, compared with a 1 percent sampling rate for the website. On the other hand, the API provides monthly data only, while the website (https://trends.google.com/trends/) provides daily (if you query less than 90 days), weekly (if less than 5 years), and monthly data. The access to the API is provided through a proprietary arrangement. We use program codes written in Python to retrieve data through the API.

\section{B. Two-layer normalization of the SVI}

Two layers of normalization are conducted in constructing an SVI. The Google servers store the information about "search volume," which is the total number of searches on query $q$ submitted to the Google search service from location $l$ in time $t$, denoted by $\operatorname{SV}_{t, l}(q)$. However, $\mathrm{SV}_{t, l}(q)$ is not available from the Google Trends service. Instead, we observe an SVI, which is defined in two normalization steps as follows. First, search volume on a query is normalized by the total search volume on all queries. That is, the search volume ratio (SVR), which is the ratio of search volume on query $q$ to search volume of all the queries that were submitted in time $t$ at location $l$-denoted by $\operatorname{SVR}_{t, l}(q)$-, is constructed as follows:

$$
\operatorname{SVR}_{t, l}(q) \stackrel{\text { def }}{=} \frac{\operatorname{SV}_{t, l}(q)}{\sum_{\tilde{q}} \mathrm{SV}_{t, l}(\tilde{q})}
$$

Second, the SVR is further normalized such that the highest value under a particular data request takes 100, which defines the SVI—denoted by $\mathrm{SVI}_{t, l}(q)$-as follows:

$$
\operatorname{SVI}_{t, l}(q) \stackrel{\text { def }}{=} \frac{\operatorname{SVR}_{t, l}(q)}{\max _{t \in T_{0}} \operatorname{SVR}_{t, l}(q)} \times 100
$$

where $T_{0}$ is the set of the time periods under the data request. Letting $t^{*}$ denote the time that attains the maximum under the data request (and hence it will change under a different data request), we have:

$$
\operatorname{SVI}_{t, l}(q)=\left[\frac{\mathrm{SV}_{t, l}(q)}{\sum_{\tilde{q}} \mathrm{SV}_{t, l}(\tilde{q})}\right]\left[\frac{\mathrm{SV}_{t^{*}, l}(q)}{\sum_{\tilde{q}} \mathrm{SV}_{t^{*}, l}(\tilde{q})}\right]^{-1} \times 100=\left[\frac{\mathrm{SV}_{t, l}(q)}{\sum_{\tilde{q}} \mathrm{SV}_{t, l}(\tilde{q})}\right] \times \text { constant }
$$

Therefore, $\mathrm{SVI}_{t, l}(q)$ is an index proportional to the frequency of searches on query $q$ relative to the frequency of searches on all the queries submitted at location $l$ at time $t$.

The two layers of normalization applied to the SVI are intended to provide an accessible and meaningful metric. The first step of the normalization controls for trivial changes in search volumes, including due to a general trend increase in search volumes observed for virtually all queries and a tendency to observe higher search volumes for queries originated from more populated locations (Stephens-Davidowitz and Varian, 2015). The second step of the normalization scales the SVI to take a value between 0 to 100 for any selection of query, time, and location, which makes the SVI accessible to wide users. 
However, the two-layer normalization complicates the analysis of the SVI. For example, an increase in an SVI for query $q$ from time $t_{1}$ to time $t_{2}\left(>t_{1}\right)$, while keeping the location the same, does not necessarily mean that query $q$ was searched more often in time $t_{2}$. Taking two SVIs yields

$$
\frac{\mathrm{SVI}_{t_{2}, l}(q)}{\mathrm{SVI}_{t_{1}, l}(q)}=\left[\frac{\mathrm{SV}_{t_{2}, l}(q)}{\mathrm{SV}_{t_{1}, l}(q)}\right]\left[\frac{\sum_{\tilde{q}} \mathrm{SV}_{t_{2}, l}(\tilde{q})}{\sum_{\tilde{q}} \mathrm{SV}_{t_{1}, l}(\tilde{q})}\right]^{-1},
$$

which fluctuates not only because of the change in the search volume for query $q$ from time $t_{1}$ to time $t_{2}$, but also because of the change in the total search volume for all the queries submitted from time $t_{1}$ to time $t_{2}$. In general, there is an increasing trend in the total number of searches over time, and thus, this ratio would increase only if the search volume for query $q$ increased at a faster pace than the increasing trend in the total number of searches.

In addition, the scaling adjustment made per data request prevents researchers from directly comparing different SVIs in levels. The units of SVIs differ across data requests to the Google Trends service. This would not be a problem if researchers could download all the SVIs of interest at once in one data request. But this is not the case in practice, not only because researchers may have second thoughts on which SVIs are needed for their analyses, but also because there are limits on the size of data requests (i.e., "quota limits"), which prevent such a massive data request at once.

\section{Making SVIs comparable}

SVIs are not comparable as they are, due to the normalization, but there is a way to make them comparable across queries-i.e., across countries in our case. Although we cannot infer search volumes in levels-i.e., $\mathrm{SV}_{t, l}(q)$ itself - due to the first layer of the normalization, we can control for the scaling per data request made in the second layer of the normalization. After downloading two SVIs to be compared for a given period, we submit one data request for the averages of the two SVIs over the period of interest and use these values to adjust one of the two SVIs to be in the same unit of the other.

The specific procedure is as follows. Consider two SVIs, denoted by $\operatorname{SVI}_{t, l}^{1}\left(q_{1}\right)$ and $\mathrm{SVI}_{t, l}^{2}\left(q_{2}\right)$, to be compared for the same $T$ periods, where superscripts 1 and 2 indicate that they are downloaded in two separate data requests. The scaling per data request results in two constants, $C_{1}$ and $C_{2}$, associated with these SVIs as follows:

$$
\operatorname{SVI}_{t, l}^{1}\left(q_{1}\right)=\left[\frac{\mathrm{SV}_{t, l}\left(q_{1}\right)}{\sum_{\tilde{q}} \mathrm{SV}_{t, l}(\tilde{q})}\right] \times C_{1}, \quad \operatorname{SVI}_{t, l}^{2}\left(q_{2}\right)=\left[\frac{\mathrm{SV}_{t, l}\left(q_{2}\right)}{\sum_{\tilde{q}} \mathrm{SV}_{t, l}(\tilde{q})}\right] \times C_{2}
$$

Downloading the averages of these SVIs over time in one data request, indicated by superscript 3 and associated with a scaling constant $C_{3}$, provides the two values as follows:

$$
\frac{1}{T} \sum_{t} \mathrm{SVI}_{t, l}^{3}\left(q_{1}\right)=\frac{1}{T} \sum_{t}\left[\frac{\mathrm{SV}_{t, l}\left(q_{1}\right)}{\sum_{\tilde{q}} \mathrm{SV}_{t, l}(\tilde{q})}\right] \times C_{3},
$$




$$
\frac{1}{T} \sum_{t} \operatorname{SVI}_{t, l}^{3}\left(q_{2}\right)=\frac{1}{T} \sum_{t}\left[\frac{\mathrm{SV}_{t, l}\left(q_{2}\right)}{\sum_{\tilde{q}} \operatorname{SV}_{t, l}(\tilde{q})}\right] \times C_{3} .
$$

Combining these, we adjust $\operatorname{SVI}_{t, l}^{2}\left(q_{2}\right)$ as follows:

$$
\operatorname{SVI}_{t, l}^{1}\left(q_{2}\right)=\operatorname{SVI}_{t, l}^{2}\left(q_{2}\right) \times\left[\frac{\frac{1}{T} \sum_{t} \operatorname{SVI}_{t, l}^{3}\left(q_{2}\right)}{\frac{1}{T} \sum_{t} \operatorname{SVI}_{t, l}^{2}\left(q_{2}\right)}\right] \times\left[\frac{\frac{1}{T} \sum_{t} \operatorname{SVI}_{t, l}^{1}\left(q_{1}\right)}{\frac{1}{T} \sum_{t} \operatorname{SVI}_{t, l}^{3}\left(q_{1}\right)}\right]=\left[\frac{\operatorname{SV}_{t, l}\left(q_{2}\right)}{\sum_{\tilde{q}} \operatorname{SV}_{t, l}(\tilde{q})}\right] \times C_{1},
$$

where $\operatorname{SVI}_{t, l}^{1}\left(q_{2}\right)$ denotes the adjusted SVI for query $q_{2}$, which has the common scaling constant $C_{1}$ with $\operatorname{SVI}_{t, l}^{1}\left(q_{1}\right)$. This way, $\operatorname{SVI}_{t, l}^{1}\left(q_{1}\right)$ and $\operatorname{SVI}_{t, l}^{1}\left(q_{2}\right)$ become comparable with each other.

We apply this adjustment bilaterally for all two pairs of SVIs of interest and make all SVIs associated with one common constant. The common constant is denoted by $C_{0}$ henceforth. The value 100 under these comparable SVIs now indicates the highest among all the SVIs over time across queries (i.e., country names) in our data set.

We cannot apply this adjustment for SVIs across categories, unfortunately. The Google Trends service does not provide the averages of SVIs across categories, which we need in the adjustment procedure. Therefore, we cannot make SVIs under different categories comparable. For example, in our data set, for Uganda, the SVI under the travel category is higher than that of the finance category, but it does not necessarily mean that more queries are submitted under the travel category than the finance category.

\section{Conditions for proper measurement of people's attention}

We establish a simple set of conditions, under which the SVI does capture the degree of people's attention to the subject of the search. Following the idea of Da, Engelberg, and Gao (2011), we assume that the search volume on query $q$ at time $t$ in location $l$ is associated with some degree of people's attention to the entity represented by query $q$, denoted by $A_{t, l}(q)$. We need to be careful in establishing the relationship between $A_{t, l}(q)$ and $\operatorname{SVI}_{t, l}(q)$, the latter of which requires access to the Internet and the use of the Google search service.

We first simply assume that $A_{t, l}(q)$ is the fraction of people who are interested in the entity represented by query $q$ :

$$
A_{t, l}(q) \stackrel{\text { def }}{=} \frac{N_{t, l}(q)}{\text { Population }_{t, l}},
$$

where Population ${ }_{t, l}$ denotes the total population and $N_{t, l}(q)$ the number of people who are interested in the entity represented by query $q$, at location $l$ in time $t$, regardless of the access to the Internet and the use of the Google search. This way, we put aside the issue of the intensive margin of people's attention, such as the case where some people may be more attentive than others. Still, we need to take it into account that only part of the people 
interested in query $q$ have access to the Internet and use the Google search to submit query $q$ (Appendix Figure 2).

Appendix Figure 2. Internet access, use of Google search, and people's attention

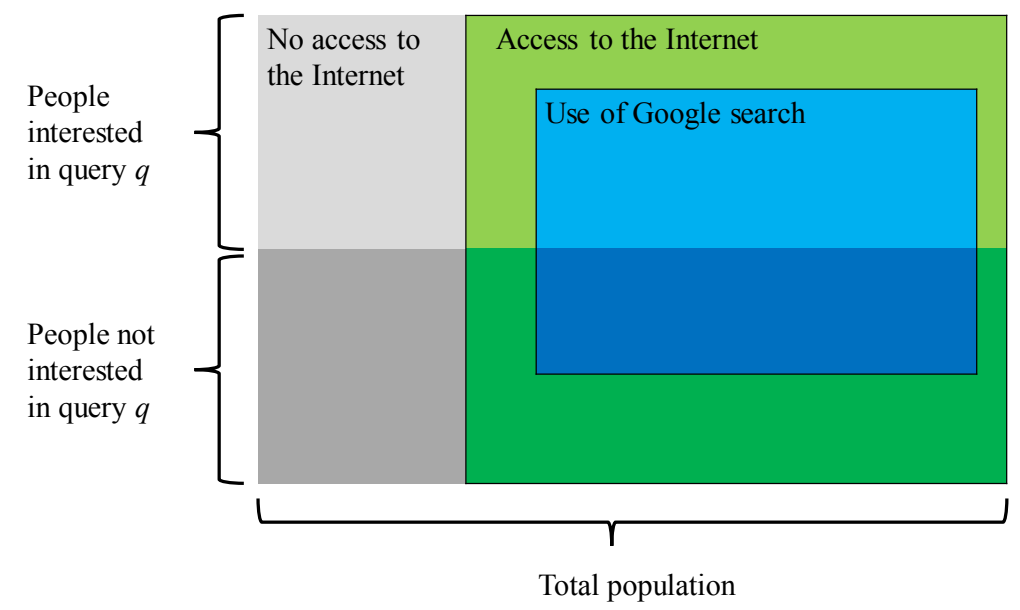

Source: Authors.

We make three assumptions to establish a meaningful relationship between the SVI and people's attention. The first assumption is about the number of searches on Google per person on average, conditional on making at least one search, which is denoted by $\bar{Q}_{t, l}(q)$. We have:

$$
\operatorname{SV}_{t, l}(q)=\bar{Q}_{t, l}(q) G_{t, l}(q), \quad \operatorname{SVI}_{t, l}(q)=\left[\frac{\bar{Q}_{t, l}(q) G_{t, l}(q)}{\sum_{\tilde{q}} \bar{Q}_{t, l}(\tilde{q}) G_{t, l}(\tilde{q})}\right] \times C_{0}
$$

where $G_{t, l}(q)$ denotes the number of people who search query $q$ (at least once) on Google and $C_{0}$ is the common constant discussed in Appendix I, Section C. The second assumption simplifies the relationship between $G_{t, l}(q)$ and the number of people interested in query $q$, $N_{t, l}(q)$. The third assumption deals with the difficulty stemming from multiple counting in the sum over all submitted queries.

\section{Assumption 1: Focus on the extensive margin}

The average number of Google searches regarding query $q$ per person, conditional on making at least one search, is constant across queries: $\bar{Q}_{t, l}(q)=\bar{Q}_{t, l}$ for any $t, l$, and $q$.

We make Assumption 1, for convenience, to focus only on the extensive margin of the search volume. Under this assumption, we have

$$
\operatorname{SVI}_{t, l}(q)=C_{0} \frac{\operatorname{SV}_{t, l}(q)}{\sum_{\tilde{q}} \operatorname{SV}_{t, l}(\tilde{q})}=C_{0} \frac{\bar{Q}_{t, l} G_{t, l}(q)}{\bar{Q}_{t, l} \sum_{\tilde{q}} G_{t, l}(\tilde{q})}=C_{0} \frac{G_{t, l}(q)}{\sum_{\tilde{q}} G_{t, l}(\tilde{q})}
$$

That is, the SVI is proportional to the fraction of people who submitted query $q$ over the total number of people who use the Google search at location $l$ in time $t$. Assumption 1 claims that the pattern of such multiple search query submissions does not change significantly or 
systemically across queries. It should be practically reasonable to consider that levels of SVIs for different queries are not entirely dominated by different degrees of multiple searches across queries (i.e., the intensive margin), but are mostly reflecting the varied number of searchers across queries (i.e., the extensive margin). Note that the Google Trends service excludes repeated searches from the same person over a short period (Google Trends Help, https://support.google.com/trends/answer/4365533?hl=en\&ref topic=6248052).

Assumption 1 may not hold in several important cases as follows. Some search activities require high-frequency updates, including seeking real-time financial investment opportunities. In this case, the SVI would be higher than the fraction of people who are interested in query $q$. Therefore, people's attention based on the SVI would be overestimated for the queries related to financial-sector activities (e.g., stock ticker symbols, the exchange rates), compared to slower other activities (e.g., car/home purchases, tourism). Another case is that people who are familiar with information technology may tend to submit more queries than others, and such familiarity with information technology may be correlated with some types of queries. Similarly, in the 2000s, most of Google searchers were people from colleges and universities (Stephens-Davidowitz and Varian, 2015) and they may have submitted search queries regarding their research activities (e.g., "science", "statistics") more frequently than usual people did for general search queries. In our application, people in the information technology industry may tend to be interested in queries about countries where the information technology industry is large or emerging (e.g., India). In this case, people's attention would be overestimated for these countries.

\section{Assumption 2: Random Google search across queries}

People have access to the Internet and submit queries of their interests to the Google search service at random with a constant probability that can depend on time $t$ and location $l$, but not depend on query $q$. In other words, there is no correlation between using the Google search service and being interested in the entity represented by query $q$.

Assumption 2 simplifies the relationship between the SVI and the number of people interested in query $q$, although the assumption may be too strong. It yields:

$$
\frac{G_{t, l}(q)}{\sum_{q} G_{t, l}(q)}=\frac{g_{t, l}(q) N_{t, l}(q)}{\sum_{\tilde{q}} g_{t, l}(\tilde{q}) N_{t, l}(\tilde{q})}=\frac{g_{t, l} N_{t, l}(q)}{g_{t, l} \sum_{\tilde{q}} N_{t, l}(\tilde{q})}=\frac{N_{t, l}(q)}{\sum_{\tilde{q}} N_{t, l}(\tilde{q})},
$$

where $g_{t, l}(q)$ denotes the probability that people who are interested in query $q$ make a search using the Google search service and, by Assumption 2, its dependence on query $q$ is dropped at the second equality. Therefore, combining with Assumption 1, the SVI is now proportionate to the number of people who are interested in query $q$. Note that this holds regardless of the improved Internet access and the increase in the use of Google search in developing countries in general during our sample period, because Assumption 2 allows the case where $g_{t, l}(q)$ can change over time and vary across locations.

Assumption 2 does not hold in the cases mostly similar to the violation of Assumption 1. As discussed for Assumption 1, the trend shift in the composition of the Google search users from people in colleges and universities to a much broader population from early 2000 s to date (Stephens-Davidowitz and Varian, 2015) indicates that the probability of searching the 
term "science" or "statistics" was higher than other terms in the 2000s, violating Assumption 2. Also, those who are interested in information technology would be more likely to use the Google search than others. Such correlation may generate an upward bias on queries about countries where the information technology industry is large or emerging (e.g., India), as discussed for Assumption 1. Assumption 2 also implicitly requires that there must be no submission of queries by the people who are not actually interested in the entities represented by those queries. Such query submissions without interest lead to a violation of Assumption 2 and add noise in the SVI.

\section{Assumption 3: Stable multiple interests}

People may well be interested in multiple queries, but the average number per person of the interested queries is constant over time and across locations.

Assumption 3 is very useful (albeit parsimonious) in establishing a connection between the SVI and economic and social fundamentals. The SVI uses the sum of all submitted queries as its denominator, but this sum is very difficult to analyze in general. Assumption 2 simplifies the denominator to the gross headcount of people who get interested in any of submitted queries. But it is still difficult to see how much such a gross headcount would be, except for a guess that it would be much larger than the population because the sum over queries should count one person several times if that person is interested in multiple queries. Assumption 3 claims that this multiple counting occurs to everyone to the same extent on average, establishing the following simple relationship:

$$
\sum_{\tilde{q}} N_{t, l}(\tilde{q})=\sum_{i} M_{t, l}(i)=\bar{M} \times \text { Population }_{t, l}
$$

where $M_{t, l}(i)$ denotes the number of queries that person $i$ at location $l$ in time $t$ is interested in, and $\bar{M}$ is the average of such a number per person, assumed to be constant by Assumption 3. The first equality holds because the sum counted over queries on the left-hand side is just recounted as the sum over persons on the right-hand side. Note that Assumption 3 has nothing to do with whether people access the Internet or how often they search on Google. Rather, Assumption 3 is about a human nature of getting interested in multiple things, which would be generic enough to justify the parsimonious assumption that the average per person would not be different across locations and over time.

\section{Proposition 1: SVI as a measure of attention}

Under Assumptions 1, 2, and 3, the SVI is proportionate to the degree of people's attention on the entity represented by a query:

$$
\operatorname{SVI}_{t, l}(q)=C_{0} \frac{G_{t, l}(q)}{\sum_{\tilde{q}} G_{t, l}(\tilde{q})}=C_{0} \frac{N_{t, l}(q)}{\sum_{\tilde{q}} N_{t, l}(\tilde{q})}=\left(\frac{C_{0}}{\bar{M}}\right) \frac{N_{t, l}(q)}{\text { Population }_{t, l}}=\left(\frac{C_{0}}{\bar{M}}\right) A_{t, l}(q)
$$

Proposition 1 formalizes the use of the SVI to analyze people's attention in general. It justifies the use of the SVI and sets a basis to discuss possible biases that could arise in the estimates based on the SVI. 


\section{E. How to detect jumps in the SVIs}

We employ a methodology in the finance literature to detect acute increases in the SVIs. We apply Lee and Mykland (2008)'s continuous-time model of the log level of stock prices to the log level of SVIs. It uses the difference between squared percent changes and consecutive absolute percent changes (called bi-power variations) to identify huge changes within a period. While the finance model is intended to be applied at a very high frequency such as a 30-minute window, we apply it to monthly data, suffering from lower efficiency and higher bias from the remaining mean drift component, which should be negligible only if the observation frequency goes to infinity. On this account, we first regress the log of SVIs on a third-order polynomial trend and the monthly dummies. We then use its residuals for calculating squared and bi-power percent changes. The jump detection is based on a statistical inference at the 1 percent significance level. It requires estimating the time-varying instantaneous volatility without jumps, for which we use the rolling-window bi-power variation over the past 36 months, excluding the current month. To keep the observations as many as possible, the rolling-window estimation is conducted forwardly (i.e., over 36 months ahead) for the first 36 months in the sample. We only focus on positive jumps and ignore negative jumps (i.e., huge drops), because an acute decrease of people's attention is not intuitive, and thus, its detection would be erroneous. To increase accuracy, we iterate the procedure once again after removing the detected jumps. Furthermore, we conduct the same procedure at the quarterly frequency, by taking period averages and setting the size of the rolling window at 12 quarters. We then take the union of jumps detected monthly and quarterly. 


\title{
APPENDiX II. SUPPLEMENTARY TABLES
}

\section{Appendix Table 1. Groupings of the economies}

\author{
Low-income developing countries (LIDCs; 59) ${ }^{\mathbf{1}}$ \\ Afghanistan, Bangladesh, Benin, Bhutan, Burkina Faso, Burundi, Cambodia, Cameroon, Central African \\ Republic, Chad, Comoros, Democratic Republic of the Congo, Republic of the Congo, Côte d'Ivoire, \\ Djibouti, Eritrea, Ethiopia, The Gambia, Ghana, Guinea, Guinea-Bissau, Haiti, Honduras, Kenya, Kiribati, \\ Kyrgyz Republic, Lao P.D.R., Lesotho, Liberia, Madagascar, Malawi, Mali, Mauritania, Moldova, \\ Mozambique, Myanmar, Nepal, Nicaragua, Niger, Nigeria, Papua New Guinea, Rwanda, São Tomé and \\ Príncipe, Senegal, Sierra Leone, Solomon Islands, Somalia, South Sudan, Sudan, Tajikistan, Tanzania, \\ Timor-Leste, Togo, Uganda, Uzbekistan, Vietnam, Yemen, Zambia, Zimbabwe
}

\section{Emerging market economies (EMEs; 95) ${ }^{2}$ \\ Albania, Algeria, Angola, Antigua and Barbuda, Argentina, Armenia, Azerbaijan, The Bahamas, Bahrain, Barbados, Belarus, Belize, Bolivia, Bosnia and Herzegovina, Botswana, Brazil, Brunei Darussalam, Bulgaria, Cabo Verde, Chile, China, Colombia, Costa Rica, Croatia, Dominica, Dominican Republic, Ecuador, Egypt, El Salvador, Equatorial Guinea, Eswatini, Fiji, Gabon, Georgia, Grenada, Guatemala, Guyana, Hungary, India, Indonesia, Iran, Iraq, Jamaica, Jordan, Kazakhstan, Kosovo, Kuwait, Lebanon, Libya, Macedonia, Malaysia, Maldives, Marshall Islands, Mauritius, Mexico, Micronesia, Mongolia, Montenegro, Morocco, Namibia, Nauru, Oman, Pakistan, Palau, Panama, Paraguay, Peru, Philippines, Poland, Qatar, Romania, Russia, Samoa, Saudi Arabia, Serbia, Seychelles, South Africa, Sri Lanka, St. Kitts and Nevis, St. Lucia, St. Vincent and the Grenadines, Suriname, Syria, Thailand, Tonga, Trinidad and Tobago, Tunisia, Turkey, Turkmenistan, Tuvalu, Ukraine, United Arab Emirates, Uruguay, Vanuatu, Venezuela}

\section{Advanced economies (AEs; 39)}

Australia, Austria, Belgium, Canada, Cyprus, Czech Republic, Denmark, Estonia, Finland, France, Germany, Greece, Hong Kong S.A.R. of China, Iceland, Ireland, Israel, Italy, Japan, Korea, Latvia, Lithuania, Luxembourg, Macao S.A.R. of China, Malta, Netherlands, New Zealand, Norway, Portugal, Puerto Rico, San Marino, Singapore, Slovak Republic, Slovenia, Spain, Sweden, Switzerland, Taiwan Province of China, United Kingdom, United States

Source: World Economic Outlook (IMF, 2018e).

${ }^{1}$ See also IMF (2018c, Appendix I) for the update of the classification of the LIDCs.

${ }^{2}$ EMEs are defined as the residual group of economies that are not included in AEs nor LIDCs. 


\section{Appendix Table 2. Categories under the Google Trends service}

\section{Panel A: Major categories}

\begin{tabular}{|ll|}
\hline & Google Trends Main Categories (25 plus all) \\
\hline All Categories & Internet \& Telecom \\
Arts \& Entertainment & Jobs \& Education \\
Autos \& Vehicles & Law \& Government \\
Beauty \& Fitness & News \\
Books \& Literature & Online Communities \\
Business \& Industrial & People \& Society \\
Computers \& Electronics & Pets \& Animals \\
Finance & Real Estate \\
Food \& Drink & Reference \\
Games & Science \\
Health & Shopping \\
Hobbies \& Leisure & Sports \\
Home \& Garden & Travel \\
\hline
\end{tabular}

\section{Panel B: Subcategories under selected five major categories}

\begin{tabular}{|c|c|c|c|c|}
\hline Finance & Business \& Industrial & $\begin{array}{l}\text { Law \& } \\
\text { Government }\end{array}$ & Health & Travel \\
\hline Accounting \& Auditing & Advertising \& Marketing & Government & Aging \& Geriatrics & Air Travel \\
\hline Banking & Aerospace \& Defense & Legal & $\begin{array}{l}\text { Alternative \& } \\
\text { Natural Medicine }\end{array}$ & Bus \& Rail \\
\hline Credit \& Lending & Agriculture \& Forestry & Military & Health Conditions & Car Rental \& Taxi Services \\
\hline $\begin{array}{l}\text { Currencies \& Foreign } \\
\text { Exchange }\end{array}$ & Automotive Industry & Public Safety & $\begin{array}{l}\text { Health Education \& } \\
\text { Medical Training }\end{array}$ & Carpooling \& Ridesharing \\
\hline Financial Planning & Business Education & $\begin{array}{l}\text { Social } \\
\text { Services }\end{array}$ & $\begin{array}{l}\text { Health Foundations } \\
\& \text { Medical Research }\end{array}$ & Cruises \& Charters \\
\hline $\begin{array}{l}\text { Grants \& Financial } \\
\text { Assistance }\end{array}$ & Business Finance & & Health News & Hotels \& Accommodations \\
\hline Insurance & Business News & & $\begin{array}{l}\text { Medical Devices \& } \\
\text { Equipment }\end{array}$ & $\begin{array}{l}\text { Luggage \& Travel } \\
\text { Accessories }\end{array}$ \\
\hline Investing & Business Operations & & $\begin{array}{l}\text { Medical Facilities } \\
\& \text { Services }\end{array}$ & Specialty Travel \\
\hline \multirow[t]{17}{*}{ Retirement \& Pension } & Business Services & & $\begin{array}{l}\text { Medical Literature } \\
\text { \& Resources }\end{array}$ & Tourist Destinations \\
\hline & Chemicals Industry & & Men's Health & Travel Agencies \& Services \\
\hline & Construction \& Maintenance & & Mental Health & Travel Guides \& Travelogues \\
\hline & Energy \& Utilities & & Nursing & \\
\hline & Enterprise Technology & & Nutrition & \\
\hline & Entertainment Industry & & Oral \& Dental Care & \\
\hline & Hospitality Industry & & Pediatrics & \\
\hline & Industrial Materials \& Equipment & & Pharmacy & \\
\hline & Manufacturing & & Public Health & \\
\hline & Metals \& Mining & & $\begin{array}{l}\text { Reproductive } \\
\text { Health }\end{array}$ & \\
\hline & Pharmaceuticals \& Biotech & & Substance Abuse & \\
\hline & Printing \& Publishing & & Women's Health & \\
\hline & Professional \& Trade Associations & & & \\
\hline & Retail Trade & & & \\
\hline & Small Business & & & \\
\hline & Textiles \& Nonwovens & & & \\
\hline & Transportation \& Logistics & & & \\
\hline
\end{tabular}

Source: Google Trends website (https://trends.google.com/trends/).

Note: Queries are assigned to categories using a natural language processing algorithm, whose details are not disclosed to the public. 


\section{Appendix Table 3. Variable definitions and data sources}

\begin{tabular}{|c|c|c|c|}
\hline Variable & Transformation & Series code & Database \\
\hline Google search volume index (SVI) & Natural logarithm & $\begin{array}{l}\text { Set a country name as a } \\
\text { search topic }\end{array}$ & Google Trends \\
\hline Foreign direct investment (FDI) inflows & Natural logarithm & IFDI & FFA \\
\hline Non-FDI private capital inflows & Natural logarithm & ICAPFLP minus IFDI & FFA \\
\hline Total private capital inflows & Natural logarithm & ICAPFLP & FFA \\
\hline Total capital inflows & Natural logarithm & ICAPFL & FFA \\
\hline $\begin{array}{l}\text { Export price growth (export-value } \\
\text { weighted average of import deflators in } \\
\text { export destination countries) }\end{array}$ & Percent change & TM_D_WX001 & WEO (GEE) \\
\hline $\begin{array}{l}\text { Import price growth (import-value } \\
\text { weighted average of export deflators in } \\
\text { import origination countries) }\end{array}$ & Percent change & TX_D_WM001 & WEO (GEE) \\
\hline $\begin{array}{l}\text { Trading partners' growth (export-value } \\
\text { weighted average of real GDP growth in } \\
\text { export destination countries) }\end{array}$ & Percent change & NGDP_R_WX001 & WEO (GEE) \\
\hline Real effective exchange rate (REER) & $\begin{array}{l}\text { Natural logarithm or } \\
\text { percent change, p.a. }\end{array}$ & EREER_IX & IFS \\
\hline Fiscal spending & Natural logarithm & GGX & WEO \\
\hline Inflation & Percent change, p.a. & PCPI_PCH & WEO \\
\hline $\begin{array}{l}\text { Nominal exchange rate (local currencies } \\
\text { to one U.S. dollar) }\end{array}$ & Percent change, p.a. & ENDA & WEO \\
\hline Population & Natural logarithm & LP & WEO \\
\hline Real exports & Natural logarithm & TX_R & WEO \\
\hline Trade openness & Natural logarithm & $\begin{array}{l}\text { (BMGS_BP6 + } \\
\text { BXGS_BP6) / NGDPD }\end{array}$ & WEO \\
\hline Age dependency ratio & None & SP.POP.DPND & WDI \\
\hline GDP (constant 2010 US\$) & Natural logarithm & NY.GDP.MKTP.KD & WDI \\
\hline International tourism, number of arrivals & Natural logarithm & ST.INT.ARVL & WDI \\
\hline International tourism, receipts & Natural logarithm & ST.INT.RCPT.CD & WDI \\
\hline Internet users (per 100 people) & Natural logarithm & IT.NET.USER.P2 & WDI \\
\hline Capital account openness index & None & KA_OPEN & $\begin{array}{l}\text { Chinn and Ito (2006), } \\
\text { updated as of July 20, } 2017 .\end{array}$ \\
\hline Nighttime lights per area, HSW (2012) & Natural logarithm & $\operatorname{lndn}$ & $\begin{array}{l}\text { Henderson, Storeygard, and } \\
\text { Weil (2012) }\end{array}$ \\
\hline Nighttime lights per area, Rnightlights & Natural logarithm & $\begin{array}{l}\text { Compiled via the } \mathrm{R} \\
\text { package, Rnightlights }\end{array}$ & Njuguna (2018) \\
\hline
\end{tabular}

Sources: Chinn and Ito (2006); Earth Observation Group; Financial Flows Analytics (FFA, IMF, 2018a); GADM (2018); Google Trends; Henderson, Storeygard, and Weil (2012); International Financial Statistics (IFS, IMF, 2018b); National Geophysical Data Center (with U.S. Air Force Weather Agency); World Development Indicators (WDI, World Bank, 2018); and World Economic Outlook (WEO, IMF, 2018e).

Note. Nighttime lights measure the light intensity at some instant during 8:30 and 10:00 pm local time, depending on the location, being digitalized as an integer between 0 (no light) to 63 (Henderson, Storeygard, and Weil, 2012). The R package Rnightlights (Njuguna, 2018) compiles nighttime light data for 1992-2013 based on DMSP OLS data and for 2015-2016 based on the Visible Infrared Imaging Radiometer Suite (VIIRS) Day/Night Band (DNB) data. The DMSP OLS data are based on the processed images provided by National Geophysical Data Center, while images are collected by U.S. Air Force Weather Agency. The VIIRS DNB data are produced by the Earth Observation Group, NOAA/NCEI. The FFA database compiled from the IMF's Balance of Payments Statistics, IFS, and WEO databases, World Bank's WDI database, Haver Analytics, CEIC Asia database, and CEIC China database. DMSP OLS: Defense Meteorological Satellite Program Operational Linescan System; GEE: Global Economic Environment; LIDCs: low-income developing countries; NCEI: National Centers for Environmental Information; NOAA: National Oceanic and Atmospheric Administration. 


\section{Appendix Table 4. Summary statistics for LIDCs}

\begin{tabular}{|c|c|c|c|c|c|c|c|}
\hline Variable & \multicolumn{3}{|c|}{ Percentiles } & Mean & $\begin{array}{l}\text { Standard } \\
\text { deviation }\end{array}$ & $\begin{array}{c}\text { Number of } \\
\text { observations }\end{array}$ & $\begin{array}{c}\text { Number of } \\
\text { countries }\end{array}$ \\
\hline Google search volume index (SVI): All & -1.40 & -0.72 & 0.22 & -0.62 & 1.18 & 767 & 59 \\
\hline SVI: Finance & -2.82 & -1.85 & -0.93 & -1.80 & 1.41 & 766 & 59 \\
\hline SVI: Business and industrial & -2.19 & -1.26 & -0.49 & -1.33 & 1.30 & 767 & 59 \\
\hline SVI: Law and government & -1.10 & -0.19 & 0.49 & -0.29 & 1.16 & 767 & 59 \\
\hline SVI: Health & -1.53 & -0.65 & 0.26 & -0.66 & 1.30 & 767 & 59 \\
\hline SVI: Travel & -2.18 & -1.18 & -0.15 & -1.14 & 1.39 & 767 & 59 \\
\hline Foreign direct investment (FDI) inflows & 4.11 & 5.64 & 6.80 & 5.35 & 2.04 & 626 & 54 \\
\hline Non-FDI private capital inflows & 4.74 & 5.82 & 6.70 & 5.60 & 1.75 & 505 & 53 \\
\hline Total private capital inflows & 5.34 & 6.39 & 7.41 & 6.26 & 1.69 & 575 & 53 \\
\hline Total capital inflows & 5.34 & 6.43 & 7.42 & 6.28 & 1.69 & 579 & 53 \\
\hline Export price growth & -3.27 & 4.31 & 8.26 & 1.85 & 7.83 & 767 & 59 \\
\hline Import price growth & -3.17 & 5.16 & 8.90 & 2.31 & 8.40 & 767 & 59 \\
\hline Trading partners' growth & 2.96 & 4.21 & 5.55 & 4.26 & 2.21 & 767 & 59 \\
\hline REER (log level) & 4.55 & 4.61 & 4.66 & 4.61 & 0.15 & 717 & 56 \\
\hline REER (percent change, p.a.) & -2.40 & 1.12 & 4.90 & 1.55 & 7.04 & 713 & 56 \\
\hline Fiscal spending & 3.40 & 5.73 & 7.54 & 5.42 & 2.99 & 746 & 58 \\
\hline Inflation & 3.12 & 6.42 & 10.04 & 8.22 & 17.01 & 746 & 58 \\
\hline Nominal exchange rate & -0.65 & 0.79 & 6.65 & 3.52 & 12.82 & 759 & 59 \\
\hline Real exports & -0.58 & 0.49 & 1.27 & 0.29 & 1.68 & 702 & 54 \\
\hline Trade openness & 3.87 & 4.16 & 4.54 & 4.20 & 0.44 & 751 & 59 \\
\hline Age dependency ratio & 70.00 & 83.74 & 91.58 & 80.55 & 16.14 & 762 & 59 \\
\hline GDP (constant 2010 US\$) & 1.32 & 2.18 & 3.07 & 2.08 & 1.51 & 724 & 57 \\
\hline International tourism, number of arrivals & 11.31 & 12.55 & 13.67 & 12.44 & 1.59 & 655 & 54 \\
\hline International tourism, receipts & 17.43 & 18.77 & 19.97 & 18.56 & 1.86 & 675 & 57 \\
\hline Internet users (per 100 people) & 0.34 & 1.37 & 2.31 & 1.26 & 1.37 & 687 & 59 \\
\hline Capital account openness index & 0.17 & 0.17 & 0.41 & 0.33 & 0.32 & 650 & 56 \\
\hline Nighttime lights per area, HSW (2012) & -2.89 & -2.09 & -1.05 & -1.99 & 1.44 & 290 & 58 \\
\hline Nighttime lights per area, Rnightlights & -2.55 & -1.62 & -0.58 & -1.61 & 1.48 & 701 & 59 \\
\hline
\end{tabular}

Sources: Chinn and Ito (2006); Earth Observation Group; Financial Flows Analytics (IMF, 2018a); GADM (2018); Google Trends; Henderson, Storeygard, and Weil (2012); International Financial Statistics (IFS, IMF, 2018b); National Geophysical Data Center (with U.S. Air Force Weather Agency); World Development Indicators (World Bank, 2018); World Economic Outlook (IMF, 2018e); and the authors' calculation.

Note. Sample period: 2004-2016. See Appendix Table 1 for country groupings and Appendix Table 3 for variable definitions (most of variables are in natural logarithm or percent change) and data sources. LIDCs: low-income developing countries; REER: real effective exchange rate. 


\section{Appendix Table 5. Pairwise correlation coefficients for selected variables for LIDCs}

\begin{tabular}{|c|c|c|c|c|c|c|c|}
\hline \multirow[t]{2}{*}{ Variable } & \multicolumn{6}{|c|}{ Google SVI } & \multirow{2}{*}{$\begin{array}{c}\text { Nighttime } \\
\text { lights per area, } \\
\text { Rnightlights }\end{array}$} \\
\hline & All & Finance & $\begin{array}{l}\text { Business and } \\
\text { Industrial }\end{array}$ & $\begin{array}{c}\text { Law and } \\
\text { Government }\end{array}$ & Health & Travel & \\
\hline $\begin{array}{l}\text { Google search volume index } \\
\text { (SVI): All }\end{array}$ & 1 & - & - & - & - & - & $0.32 *$ \\
\hline SVI: Finance & $0.93 *$ & 1 & - & - & - & - & $0.42 *$ \\
\hline SVI: Business and industrial & $0.92 *$ & $0.92 *$ & 1 & - & - & - & $0.34 *$ \\
\hline SVI: Law and government & $0.96 *$ & $0.91 *$ & $0.92 *$ & 1 & - & - & $0.32 *$ \\
\hline SVI: Health & $0.96 *$ & $0.92 *$ & $0.91 *$ & $0.92 *$ & 1 & - & $0.28 *$ \\
\hline SVI: Travel & $0.83 *$ & $0.83 *$ & $0.78 *$ & $0.77 *$ & $0.81 *$ & 1 & $0.38 *$ \\
\hline GDP (constant 2010 US\$) & $0.83 *$ & $0.82 *$ & $0.82 *$ & $0.82 *$ & $0.81 *$ & $0.58 *$ & $0.24 *$ \\
\hline Real exports & $0.78^{*}$ & $0.82 *$ & $0.84 *$ & $0.79 *$ & $0.76^{*}$ & $0.64 *$ & $0.32 *$ \\
\hline International tourism, arrivals & $0.73 *$ & $0.78 *$ & $0.76^{*}$ & $0.74 *$ & $0.71 *$ & $0.67 *$ & $0.35^{*}$ \\
\hline International tourism, receipts & $0.72 *$ & $0.72 *$ & $0.69 *$ & $0.70 *$ & $0.70 *$ & $0.72 *$ & $0.30 *$ \\
\hline Inflation & 0.06 & 0.05 & 0.04 & 0.07 & 0.05 & 0.01 & -0.05 \\
\hline Nominal exchange rate & 0.06 & $0.10 *$ & 0.04 & 0.04 & 0.06 & -0.01 & -0.04 \\
\hline $\begin{array}{l}\text { Real effective exchange rate } \\
\text { (percent change, p.a.) }\end{array}$ & 0.06 & 0.01 & 0.02 & 0.05 & 0.04 & 0.03 & -0.00 \\
\hline $\begin{array}{l}\text { Foreign direct investment } \\
\text { (FDI) inflows }\end{array}$ & $0.56^{*}$ & $0.59 *$ & $0.59 *$ & $0.52 *$ & $0.57 *$ & $0.46^{*}$ & $0.14 *$ \\
\hline $\begin{array}{l}\text { Non-FDI private capital } \\
\text { inflows }\end{array}$ & $0.66^{*}$ & $0.68 *$ & $0.68 *$ & $0.64 *$ & $0.67 *$ & $0.51 \%$ & $0.17 *$ \\
\hline Total private capital inflows & $0.67 *$ & $0.70 *$ & $0.69 *$ & $0.66^{*}$ & $0.67 *$ & $0.51 *$ & $0.15^{*}$ \\
\hline Total capital inflows & $0.67 *$ & $0.70 *$ & $0.69 *$ & $0.66^{*}$ & $0.67 *$ & $0.50 *$ & $0.14 *$ \\
\hline Export price growth & -0.05 & -0.09 & -0.04 & -0.00 & -0.03 & 0.04 & 0.07 \\
\hline Import price growth & -0.06 & $-0.11 *$ & -0.04 & -0.02 & -0.04 & 0.03 & 0.07 \\
\hline Trading partners' growth & $-0.13 *$ & $-0.18 *$ & $-0.21 *$ & -0.09 & $-0.13 *$ & $-0.12 *$ & $-0.13 *$ \\
\hline Fiscal spending & $0.44 *$ & $0.38 *$ & $0.40 *$ & $0.41 *$ & $0.43 *$ & $0.32 *$ & 0.09 \\
\hline Trade openness & $-0.12 *$ & -0.08 & 0.01 & $-0.11 *$ & $-0.12 *$ & 0.08 & $0.18 *$ \\
\hline Age dependency ratio & $-0.21 *$ & $-0.26^{*}$ & $-0.20 *$ & $-0.22 *$ & $-0.13 *$ & $-0.31 *$ & $-0.56 *$ \\
\hline Internet users (per 100 people) & $0.21 *$ & $0.32 *$ & $0.25 *$ & $0.20 *$ & $0.17 *$ & $0.23 *$ & $0.53 *$ \\
\hline Capital account openness index & 0.08 & $0.11 *$ & 0.07 & $0.12 *$ & 0.09 & $0.19 *$ & $0.18 *$ \\
\hline $\begin{array}{l}\text { Nighttime lights per area, } \\
\text { HSW (2012) }\end{array}$ & $0.26^{*}$ & $0.40 *$ & $0.29 *$ & $0.27 *$ & $0.19 *$ & $0.32 *$ & $0.99 *$ \\
\hline $\begin{array}{l}\text { Nighttime lights per area, } \\
\text { Rnightlights }\end{array}$ & $0.32 *$ & $0.42 *$ & $0.34 *$ & $0.32 *$ & $0.28 *$ & $0.38^{*}$ & 1 \\
\hline
\end{tabular}

Sources: Chinn and Ito (2006); Earth Observation Group; Financial Flows Analytics (IMF, 2018a); GADM (2018); Google Trends; Henderson, Storeygard, and Weil (2012); International Financial Statistics (IMF, 2018b); National Geophysical Data Center (with U.S. Air Force Weather Agency); World Development Indicators (World Bank, 2018); World Economic Outlook (IMF, 2018e); and the authors' calculation.

Note. Sample period: 2004-2016. Superscript * indicates significance at the one percent level. See Appendix Table 1 for country groupings and Appendix Table 3 for variable definitions (most of variables are in natural logarithm or percent change) and data sources. LIDCs: low-income developing countries. 


\section{Appendix Table 6. Nighttime lights (NLs) and real GDP in LIDCs}

\begin{tabular}{|c|c|c|c|c|c|c|c|c|}
\hline & (1) & (2) & (3) & (4) & $(5)$ & (6) & (7) & (8) \\
\hline Dependent variables & \multicolumn{8}{|c|}{ Real GDP } \\
\hline $\begin{array}{l}\text { NLs from } \\
\text { HSW (2012) } \\
\text { NLs from } \\
\text { HSW (2012) (lag) }\end{array}$ & $\begin{array}{r}0.245^{* * * *} \\
(0.058)\end{array}$ & & & & $\begin{array}{c}0.084^{*} \\
(0.046) \\
-0.076^{* *} \\
(0.035)\end{array}$ & $\begin{array}{c}0.017 \\
(0.018) \\
-0.007 \\
(0.014)\end{array}$ & & \\
\hline $\begin{array}{l}\text { NLs from } \\
\text { Rnightlights } \\
\text { NLs from } \\
\text { Rnightlights (lag) }\end{array}$ & & $\begin{array}{c}0.244 * * * \\
(0.061)\end{array}$ & $\begin{array}{c}0.246^{* * *} \\
(0.053)\end{array}$ & $\begin{array}{c}0.257 * * * \\
(0.048)\end{array}$ & & & $\begin{array}{c}0.067 * \\
(0.036) \\
-0.063 * * \\
(0.029)\end{array}$ & $\begin{array}{c}0.015 \\
(0.013) \\
-0.007 \\
(0.009)\end{array}$ \\
\hline Lagged real GDP & & & & & $\begin{array}{c}0.897 * * * \\
(0.039)\end{array}$ & $\begin{array}{c}0.789 * * * \\
(0.047)\end{array}$ & $\begin{array}{c}0.925 * * * \\
(0.022)\end{array}$ & $\begin{array}{c}0.855^{* * * *} \\
(0.035)\end{array}$ \\
\hline $\begin{array}{l}\text { Other lagged } \\
\text { controls included }\end{array}$ & NO & NO & NO & NO & NO & YES & NO & YES \\
\hline Observations & 917 & 917 & 1,196 & 1,306 & 861 & 382 & 1,194 & 686 \\
\hline Sample period & $\begin{array}{l}1992- \\
2008\end{array}$ & $\begin{array}{l}1992- \\
2008\end{array}$ & $\begin{array}{l}1992- \\
2013\end{array}$ & $\begin{array}{l}1992-2013, \\
2015-2016\end{array}$ & $\begin{array}{l}1992- \\
2008\end{array}$ & $\begin{array}{l}1992- \\
2008\end{array}$ & $\begin{array}{l}1992-2013, \\
2015-2016\end{array}$ & $\begin{array}{l}\text { 1992-2013, } \\
2015-2016\end{array}$ \\
\hline Number of countries & 56 & 56 & 57 & 57 & 56 & 53 & 56 & 53 \\
\hline Adjusted R-squared & 0.697 & 0.695 & 0.776 & 0.801 & 0.932 & 0.936 & 0.967 & 0.973 \\
\hline Country fixed effects & YES & YES & YES & YES & YES & YES & YES & YES \\
\hline Time dummies & YES & YES & YES & YES & YES & YES & YES & YES \\
\hline
\end{tabular}

Sources: Chinn and Ito (2006); Earth Observations Group; GADM (2018); Google Trends; Henderson, Storeygard, and Weil (2012); National Geophysical Data Center (with U.S. Air Force Weather Agency); World Development Indicators (World Bank, 2018); World Economic Outlook (IMF, 2018e); and the authors' estimation.

Note. Cluster-robust standard errors are reported in parentheses. Superscripts *, **, and *** indicate statistical significance at the 10 percent, 5 percent, and 1 percent level, respectively. The "NLs from HSW (2012)" line shows the coefficients on NLs data (variable lndn) compiled by Henderson, Storeygard, and Weil (2012), available for 1992-2008. The "NL from Rnightlights" line shows the coefficients on NL data compiled by the R package Rnightlights developed by Njuguna (2018), available for 1992-2013 based on DMSP OLS data (also used by Henderson, Storeygard, and Weil, 2012) and for 2015-2016 based on the Visible Infrared Imaging Radiometer Suite (VIIRS) Day/Night Band (DNB). The DMSP OLS data are based on the processed images provided by National Geophysical Data Center, while images are collected by U.S. Air Force Weather Agency. The VIIRS data are produced by the Earth Observation Group, NOAA/NCEI. See Appendix Table 1 for country groupings and Appendix Table 3 for variable definitions (most of variables are in natural logarithm or percent change) and data sources. DMSP OLS: Defense Meteorological Satellite Program Operational Linescan System; LIDCs: low-income developing countries; NCEI: National Centers for Environmental Information; NOAA: National Oceanic and Atmospheric Administration; REER: real effective exchange rate; SVI: search volume index. 


\section{Appendix Table 7. Nighttime lights (NLs) and real GDP in EMEs}

\begin{tabular}{|c|c|c|c|c|c|c|c|c|}
\hline Dependent variables & (1) & (2) & (3) & (4) $\mathrm{Re}$ & $\begin{array}{r}\quad(5) \\
1 \text { GDP }\end{array}$ & (6) & (7) & (8) \\
\hline $\begin{array}{l}\text { NLs from } \\
\text { HSW (2012) } \\
\text { NLs from } \\
\text { HSW (2012) (lag) }\end{array}$ & $\begin{array}{c}0.298^{* * *} \\
(0.058)\end{array}$ & & & & $\begin{array}{c}0.035 \\
(0.021) \\
-0.077 * * * \\
(0.021)\end{array}$ & $\begin{array}{c}0.032 * \\
(0.016) \\
-0.035 \\
(0.024)\end{array}$ & & \\
\hline $\begin{array}{l}\text { NLs from } \\
\text { Rnightlights } \\
\text { NLs from } \\
\text { Rnightlights (lag) }\end{array}$ & & $\begin{array}{c}0.272 * * * \\
(0.065)\end{array}$ & $\begin{array}{c}0.332 * * * \\
(0.060)\end{array}$ & $\begin{array}{c}0.237 * * * \\
(0.045)\end{array}$ & & & $\begin{array}{c}0.049 * * \\
(0.024) \\
-0.054 * * * \\
(0.020)\end{array}$ & $\begin{array}{c}0.033 * * \\
(0.013) \\
-0.033 * * * \\
(0.011)\end{array}$ \\
\hline Lagged real GDP & & & & & $\begin{array}{c}0.892 * * * \\
(0.044)\end{array}$ & $\begin{array}{c}0.893 * * * \\
(0.063)\end{array}$ & $\begin{array}{c}0.903 * * * \\
(0.038)\end{array}$ & $\begin{array}{c}0.912 * * * \\
(0.022)\end{array}$ \\
\hline $\begin{array}{l}\text { Other lagged } \\
\text { controls included }\end{array}$ & NO & NO & NO & $\mathrm{NO}$ & $\mathrm{NO}$ & YES & NO & YES \\
\hline Observations & 1,459 & 1,327 & 1,727 & 1,885 & 1,369 & 498 & 1,726 & 897 \\
\hline Sample period & $\begin{array}{l}1992- \\
2008\end{array}$ & $\begin{array}{l}1992- \\
2008\end{array}$ & $\begin{array}{l}1992- \\
2013\end{array}$ & $\begin{array}{l}1992-2013, \\
2015-2016\end{array}$ & $\begin{array}{l}1992- \\
2008\end{array}$ & $\begin{array}{l}1992- \\
2008\end{array}$ & $\begin{array}{l}1992-2013, \\
2015-2016\end{array}$ & $\begin{array}{l}1992-2013, \\
2015-2016\end{array}$ \\
\hline Number of countries & 88 & 80 & 80 & 80 & 88 & 67 & 80 & 71 \\
\hline Adjusted R-squared & 0.777 & 0.770 & 0.798 & 0.795 & 0.952 & 0.955 & 0.962 & 0.975 \\
\hline Country fixed effects & YES & YES & YES & YES & YES & YES & YES & YES \\
\hline Time dummies & YES & YES & YES & YES & YES & YES & YES & YES \\
\hline
\end{tabular}

Sources: Chinn and Ito (2006); Earth Observations Group; GADM (2018); Google Trends; Henderson, Storeygard, and Weil (2012); National Geophysical Data Center (with U.S. Air Force Weather Agency); World Development Indicators (World Bank, 2018); World Economic Outlook (IMF, 2018e); and the authors' estimation.

Note. Cluster-robust standard errors are reported in parentheses. Superscripts *, **, and *** indicate statistical significance at the 10 percent, 5 percent, and 1 percent level, respectively. The "NLs from HSW (2012)" line shows the coefficients on NLs data (variable lndn) compiled by Henderson, Storeygard, and Weil (2012), available for 1992-2008. The "NL from Rnightlights" line shows the coefficients on NL data compiled by the R package Rnightlights developed by Njuguna (2018), available for 1992-2013 based on DMSP OLS data (also used by Henderson, Storeygard, and Weil, 2012) and for 2015-2016 based on the Visible Infrared Imaging Radiometer Suite (VIIRS) Day/Night Band (DNB). The DMSP OLS data are based on the processed images provided by National Geophysical Data Center, while images are collected by U.S. Air Force Weather Agency. The VIIRS data are produced by the Earth Observation Group, NOAA/NCEI. See Appendix Table 1 for country groupings and Appendix Table 3 for variable definitions (most of variables are in natural logarithm or percent change) and data sources. Among EMEs, the NL data exclude countries identified as outliers by Henderson, Storeygard, and Weil (2012, footnote 16, p. 1011; Bahrain, Equatorial Guinea, Serbia, Montenegro). For the data compiled by Rnightlights, several large economies are also excluded due to their heavy computational burden (Brazil, Chile, China, Indonesia, India, Mexico, Peru, Russia). DMSP OLS: Defense Meteorological Satellite Program Operational Linescan System; EMEs: emerging market economies; NCEI: National Centers for Environmental Information; NOAA: National Oceanic and Atmospheric Administration; REER: real effective exchange rate; SVI: search volume index. 


\section{Appendix Table 8. Best specifications that minimize out-of-sample MSE for LIDCs}

\begin{tabular}{|c|c|c|}
\hline $\begin{array}{l}\text { Dependent } \\
\text { variable }\end{array}$ & $\begin{array}{l}\text { Independent } \\
\text { variables }\end{array}$ & $\begin{array}{l}\text { Specification that minimize the MSE in out-of-sample forecasting } \\
\text { for } 2013-2016\end{array}$ \\
\hline \multirow[t]{2}{*}{ Real GDP } & Controls only & $\begin{array}{l}\text { Lagged dependent variable, population, trade openness, fiscal spending, } \\
\text { inflation, trading partners' growth }\end{array}$ \\
\hline & Controls + SVIs & $\begin{array}{l}\text { Lagged dependent variable, population, Internet users, trade openness, fiscal } \\
\text { spending, inflation, finance SVI, law-government SVI }\end{array}$ \\
\hline \multirow[t]{2}{*}{ Real exports } & Controls only & $\begin{array}{l}\text { Lagged dependent variable, trade openness, fiscal spending, REER, capital } \\
\text { openness, age dependency ratio }\end{array}$ \\
\hline & Controls + SVIs & $\begin{array}{l}\text { Lagged dependent variable, fiscal spending, REER, capital openness, age } \\
\text { dependency ratio, health SVI }\end{array}$ \\
\hline \multirow[t]{2}{*}{$\begin{array}{l}\text { Tourist } \\
\text { arrivals }\end{array}$} & Controls only & $\begin{array}{l}\text { Lagged dependent variable, trade openness, fiscal spending, REER, trading } \\
\text { partners' growth }\end{array}$ \\
\hline & Controls + SVIs & $\begin{array}{l}\text { Lagged dependent variable, trade openness, fiscal spending, REER, trading } \\
\text { partners' growth, export price growth, health SVI, travel SVI }\end{array}$ \\
\hline \multirow[t]{2}{*}{ Inflation } & Controls only & $\begin{array}{l}\text { Lagged dependent variable, population, trade openness, REER (percent } \\
\text { change) }\end{array}$ \\
\hline & Controls + SVIs & $\begin{array}{l}\text { Lagged dependent variable, population, fiscal spending, REER (percent } \\
\text { change), finance SVI, business-industrial SVI, health SVI, travel SVI }\end{array}$ \\
\hline \multirow{2}{*}{$\begin{array}{l}\text { Nominal } \\
\text { exchange rate }\end{array}$} & Controls only & Lagged dependent variable, Internet users, import price growth \\
\hline & Controls + SVIs & $\begin{array}{l}\text { Real GDP, import price growth, age dependency ratio, finance SVI, } \\
\text { business-industrial SVI, law-government SVI, travel SVI }\end{array}$ \\
\hline \multirow{2}{*}{$\begin{array}{l}\text { Private capital } \\
\text { inflows }\end{array}$} & Controls only & Internet users, real GDP, trade openness, trading partners' growth \\
\hline & Controls + SVIs & $\begin{array}{l}\text { Internet users, real GDP, trade openness, export price growth, business- } \\
\text { industrial SVI, health SVI, travel SVI }\end{array}$ \\
\hline \multirow[t]{2}{*}{ FDI inflows } & Controls only & $\begin{array}{l}\text { Lagged dependent variable, population, real GDP, REER, trading partners' } \\
\text { growth }\end{array}$ \\
\hline & Controls + SVIs & $\begin{array}{l}\text { Lagged dependent variable, population, Internet users, real GDP, REER, } \\
\text { export price growth, finance SVI, business-industrial SVI, health SVI }\end{array}$ \\
\hline
\end{tabular}

Sources: Chinn and Ito (2006), Google Trends, Financial Flows Analytics (IMF, 2018a), International Financial Statistics (IMF, 2018b), World Development Indicators (World Bank, 2018), World Economic Outlook (IMF, 2018e), and the authors' estimation.

Note. All control variables are one-year lagged, while SVIs are contemporaneous. See the note under Table 7 for the estimation details. See Appendix Table 1 for country groupings and Appendix Table 3 for variable definitions (most of variables are in natural logarithm or percent change) and data sources. LIDCs: low-income developing countries; MSE: mean square error; REER: real effective exchange rate; SVI: search volume index. 


\section{Appendix Table 9. Best specifications that minimize out-of-sample MSE for EMEs}

\begin{tabular}{|c|c|c|}
\hline $\begin{array}{l}\text { Dependent } \\
\text { variable }\end{array}$ & $\begin{array}{l}\text { Independent } \\
\text { variables }\end{array}$ & $\begin{array}{l}\text { Specification that minimize the MSE in out-of-sample forecasting } \\
\text { for } 2013-2016\end{array}$ \\
\hline \multirow[t]{2}{*}{ Real GDP } & Controls only & $\begin{array}{l}\text { Lagged dependent variable, Internet users, trade openness, fiscal spending, } \\
\text { trading partners' growth, capital openness, age dependency ratio }\end{array}$ \\
\hline & Controls + SVIs & $\begin{array}{l}\text { Lagged dependent variable, trade openness, fiscal spending, trading } \\
\text { partners' growth, capital openness, age dependency ratio, finance SVI, } \\
\text { business-industrial SVI }\end{array}$ \\
\hline \multirow[t]{2}{*}{ Real exports } & Controls only & $\begin{array}{l}\text { Lagged dependent variable, population, inflation, trading partners' growth } \\
\text { age dependency ratio }\end{array}$ \\
\hline & Controls + SVIs & $\begin{array}{l}\text { Lagged dependent variable, Internet users, REER, inflation, trading partne } \\
\text { growth, age dependency ratio, finance SVI, law-government SVI, travel } \\
\text { SVI }\end{array}$ \\
\hline \multirow[t]{2}{*}{$\begin{array}{l}\text { Tourist } \\
\text { arrivals }\end{array}$} & Controls only & $\begin{array}{l}\text { Lagged dependent variable, Internet users, trade openness, REER, export } \\
\text { price growth }\end{array}$ \\
\hline & Controls + SVIs & (same as above) \\
\hline \multirow[t]{2}{*}{ Inflation } & Controls only & $\begin{array}{l}\text { Lagged dependent variable, Internet users, import price growth, capital } \\
\text { openness }\end{array}$ \\
\hline & Controls + SVIs & $\begin{array}{l}\text { Lagged dependent variable, Internet users, import price growth, capital } \\
\text { openness, business-industrial SVI, law-government SVI, health SVI, } \\
\text { travel SVI }\end{array}$ \\
\hline
\end{tabular}
Nominal Controls only Lagged dependent variable, Internet users, fiscal spending, inflation, trading exchange rate
Controls + SVIs Lagged dependent variable, Internet users, fiscal spending, inflation, trading partners' growth, import price growth, finance SVI, law-government SVI
Private capital Controls only inflows
Lagged dependent variable, trade openness, REER, inflation, trading partners' growth, capital openness
Controls + SVIs Lagged dependent variable, real GDP, trade openness, fiscal spending, REER, inflation, trading partners' growth, export price growth, capital openness, age dependency ratio, finance SVI, business-industrial SVI, travel SVI

FDI inflows Controls only Lagged dependent variable, REER, trading partners' growth, export price growth, age dependency ratio

Controls + SVIs (Same as above)

Sources: Chinn and Ito (2006), Google Trends, Financial Flows Analytics (IMF, 2018a), International Financial Statistics (IMF, 2018b), World Development Indicators (World Bank, 2018), World Economic Outlook (IMF, 2018e), and the authors' estimation.

Note. All control variables are one-year lagged, while SVIs are contemporaneous. See the note under Table 7 for the estimation details. See Appendix Table 1 for country groupings and Appendix Table 3 for variable definitions (most of variables are in natural logarithm or percent change) and data sources. EMEs: emerging market economies; MSE: mean square error; REER: real effective exchange rate; SVI: search volume index. 
Appendix Table 10. Regressions, excluding periods with jumps in SVIs, for LIDCs

\begin{tabular}{|c|c|c|c|c|c|c|c|}
\hline Dependent variables & $\begin{array}{c}(1) \\
\text { Real } \\
\text { GDP }\end{array}$ & $\begin{array}{c}(2) \\
\text { Real } \\
\text { exports }\end{array}$ & $\begin{array}{c}\text { (3) } \\
\text { Tourist } \\
\text { arrivals }\end{array}$ & $\begin{array}{c}\text { (4) } \\
\text { Inflation }\end{array}$ & $\begin{array}{c}\text { (5) } \\
\text { Nominal } \\
\text { exchange } \\
\text { rate }\end{array}$ & $\begin{array}{c}\text { (6) } \\
\text { Private } \\
\text { capital } \\
\text { inflows }\end{array}$ & $\begin{array}{c}(7) \\
\text { FDI } \\
\text { inflows }\end{array}$ \\
\hline SVI: Finance & $\begin{array}{l}-0.00 \\
(0.01)\end{array}$ & $\begin{array}{c}0.04 \\
(0.06)\end{array}$ & $\begin{array}{l}-0.06 \\
(0.11)\end{array}$ & $\begin{array}{c}3.43 * * \\
(1.35)\end{array}$ & $\begin{array}{c}10.07 * * * \\
(3.19)\end{array}$ & $\begin{array}{l}-0.35 \\
(0.23)\end{array}$ & $\begin{array}{c}0.05 \\
(0.33)\end{array}$ \\
\hline SVI: Business and industrial & $\begin{array}{c}0.11 * * * \\
(0.03)\end{array}$ & $\begin{array}{c}0.18 \\
(0.11)\end{array}$ & $\begin{array}{c}0.48 * * \\
(0.22)\end{array}$ & $\begin{array}{l}-2.52 \\
(1.77)\end{array}$ & $\begin{array}{l}-2.14 \\
(5.13)\end{array}$ & $\begin{array}{c}1.71 * * * \\
(0.40)\end{array}$ & $\begin{array}{c}1.24 \\
(0.75)\end{array}$ \\
\hline SVI: Law and government & $\begin{array}{c}-0.05 * * * \\
(0.02)\end{array}$ & $\begin{array}{c}-0.27 * * \\
(0.11)\end{array}$ & $\begin{array}{c}-0.37 * * \\
(0.15)\end{array}$ & $\begin{array}{c}0.56 \\
(1.61)\end{array}$ & $\begin{array}{c}-6.51 * * \\
(2.59)\end{array}$ & $\begin{array}{c}0.00 \\
(0.33)\end{array}$ & $\begin{array}{l}-0.65 \\
(0.41)\end{array}$ \\
\hline SVI: Health & $\begin{array}{c}-0.06^{* *} \\
(0.02)\end{array}$ & $\begin{array}{l}-0.01 \\
(0.05)\end{array}$ & $\begin{array}{c}-0.34 * * \\
(0.13)\end{array}$ & $\begin{array}{l}2.18^{*} \\
(1.20)\end{array}$ & $\begin{array}{c}0.89 \\
(2.47)\end{array}$ & $\begin{array}{c}-0.67^{* *} \\
(0.30)\end{array}$ & $\begin{array}{l}-0.40 \\
(0.43)\end{array}$ \\
\hline SVI: Travel & $\begin{array}{c}0.02 \\
(0.01) \\
\end{array}$ & $\begin{array}{c}0.04 \\
(0.07) \\
\end{array}$ & $\begin{array}{c}0.28 * * \\
(0.11)\end{array}$ & $\begin{array}{c}-4.33 * * \\
(1.67)\end{array}$ & $\begin{array}{l}-2.45 \\
(2.62) \\
\end{array}$ & $\begin{array}{c}-0.72 * * * \\
(0.24)\end{array}$ & $\begin{array}{l}-0.19 \\
(0.34) \\
\end{array}$ \\
\hline Lagged dependent variable & $\begin{array}{c}0.78 * * * \\
(0.05)\end{array}$ & $\begin{array}{c}0.83 * * * \\
(0.05)\end{array}$ & $\begin{array}{c}0.60 * * * \\
(0.07)\end{array}$ & $\begin{array}{c}0.28 * * * \\
(0.05)\end{array}$ & $\begin{array}{c}0.16^{* * *} \\
(0.06)\end{array}$ & $\begin{array}{c}0.03 \\
(0.10)\end{array}$ & $\begin{array}{l}0.19^{*} \\
(0.10)\end{array}$ \\
\hline Population (lag) & $\begin{array}{c}0.05 \\
(0.07)\end{array}$ & $\begin{array}{c}0.42 \\
(0.57)\end{array}$ & $\begin{array}{l}-0.57 \\
(0.50)\end{array}$ & $\begin{array}{c}-3.50 \\
(17.39)\end{array}$ & $\begin{array}{c}6.02 \\
(21.27)\end{array}$ & $\begin{array}{l}-3.25^{*} \\
(1.61)\end{array}$ & $\begin{array}{l}-0.42 \\
(1.73)\end{array}$ \\
\hline Internet users (lag) & $\begin{array}{l}-0.00 \\
(0.00)\end{array}$ & $\begin{array}{c}0.03 \\
(0.02)\end{array}$ & $\begin{array}{l}0.05^{*} \\
(0.03)\end{array}$ & $\begin{array}{c}0.84 \\
(0.50)\end{array}$ & $\begin{array}{c}0.86 \\
(0.92)\end{array}$ & $\begin{array}{c}0.03 \\
(0.09)\end{array}$ & $\begin{array}{c}0.00 \\
(0.13)\end{array}$ \\
\hline Real GDP (lag) & & $\begin{array}{l}-0.44^{*} \\
(0.22)\end{array}$ & $\begin{array}{c}-0.48 * * \\
(0.23)\end{array}$ & $\begin{array}{c}2.55 \\
(3.36)\end{array}$ & $\begin{array}{c}2.19 \\
(5.63)\end{array}$ & $\begin{array}{c}1.14 \\
(0.80)\end{array}$ & $\begin{array}{l}1.89^{*} \\
(1.02)\end{array}$ \\
\hline Trade openness (lag) & $\begin{array}{c}0.01 \\
(0.01)\end{array}$ & $\begin{array}{l}-0.07 \\
(0.10)\end{array}$ & $\begin{array}{c}-0.28 * * \\
(0.10)\end{array}$ & $\begin{array}{c}1.51 \\
(1.56)\end{array}$ & $\begin{array}{c}-7.25 * * \\
(2.97)\end{array}$ & $\begin{array}{c}0.70 * * \\
(0.27)\end{array}$ & $\begin{array}{l}0.68^{*} \\
(0.34)\end{array}$ \\
\hline Fiscal spending (lag) & $\begin{array}{c}0.02 * * \\
(0.01)\end{array}$ & $\begin{array}{c}0.02 \\
(0.05)\end{array}$ & $\begin{array}{c}0.19 * * * \\
(0.07)\end{array}$ & $\begin{array}{l}-1.76 \\
(1.38)\end{array}$ & $\begin{array}{c}-6.68 * * * \\
(2.23)\end{array}$ & $\begin{array}{c}0.44 \\
(0.27)\end{array}$ & $\begin{array}{l}-0.10 \\
(0.28)\end{array}$ \\
\hline REER, log level (lag) & $\begin{array}{l}-0.01 \\
(0.02)\end{array}$ & $\begin{array}{c}0.11 \\
(0.09)\end{array}$ & $\begin{array}{c}-0.33 * * \\
(0.14)\end{array}$ & & & $\begin{array}{l}-0.02 \\
(0.47)\end{array}$ & $\begin{array}{l}-0.15 \\
(0.45)\end{array}$ \\
\hline REER, percent change (lag) & & & & $\begin{array}{c}-0.20 * * * \\
(0.04)\end{array}$ & & & \\
\hline Inflation (lag) & $\begin{array}{c}-0.00 * * \\
(0.00)\end{array}$ & $\begin{array}{l}-0.00 \\
(0.00)\end{array}$ & $\begin{array}{l}-0.00 \\
(0.00)\end{array}$ & & $\begin{array}{c}-0.12 * * * \\
(0.03)\end{array}$ & $\begin{array}{l}-0.00 \\
(0.01)\end{array}$ & $\begin{array}{l}-0.00 \\
(0.01)\end{array}$ \\
\hline Trading partners' growth (lag) & $\begin{array}{l}-0.00 \\
(0.00)\end{array}$ & $\begin{array}{l}-0.01 \\
(0.01)\end{array}$ & $\begin{array}{c}0.01 \\
(0.01)\end{array}$ & $\begin{array}{c}0.07 \\
(0.31)\end{array}$ & $\begin{array}{l}-0.21 \\
(0.39)\end{array}$ & $\begin{array}{c}0.04 \\
(0.04)\end{array}$ & $\begin{array}{c}0.03 \\
(0.03)\end{array}$ \\
\hline Export price growth (lag) & $\begin{array}{c}0.00 \\
(0.00)\end{array}$ & $\begin{array}{c}0.00 \\
(0.01)\end{array}$ & $\begin{array}{l}-0.00 \\
(0.01)\end{array}$ & & & $\begin{array}{c}0.02 * * \\
(0.01)\end{array}$ & $\begin{array}{l}0.03^{*} \\
(0.01)\end{array}$ \\
\hline Import price growth (lag) & & & & $\begin{array}{c}0.08 \\
(0.08)\end{array}$ & $\begin{array}{l}-0.13 \\
(0.12)\end{array}$ & & \\
\hline Capital account openness (lag) & $\begin{array}{l}-0.01 \\
(0.01)\end{array}$ & $\begin{array}{c}0.07 \\
(0.10)\end{array}$ & $\begin{array}{c}0.02 \\
(0.12)\end{array}$ & $\begin{array}{l}-0.57 \\
(2.49)\end{array}$ & $\begin{array}{l}-3.82 \\
(3.62)\end{array}$ & $\begin{array}{c}0.52 \\
(0.45)\end{array}$ & $\begin{array}{l}-0.91 * \\
(0.46)\end{array}$ \\
\hline Age dependency ratio (lag) & $\begin{array}{c}0.00 \\
(0.00) \\
\end{array}$ & $\begin{array}{l}-0.00 \\
(0.01) \\
\end{array}$ & $\begin{array}{c}0.01 \\
(0.01) \\
\end{array}$ & $\begin{array}{c}0.03 \\
(0.13) \\
\end{array}$ & $\begin{array}{c}0.27 \\
(0.20) \\
\end{array}$ & $\begin{array}{c}0.00 \\
(0.03) \\
\end{array}$ & $\begin{array}{c}0.00 \\
(0.02) \\
\end{array}$ \\
\hline Observations & 503 & 494 & 455 & 500 & 524 & 355 & 422 \\
\hline Number of countries & 53 & 52 & 51 & 53 & 54 & 48 & 48 \\
\hline Adjusted R-squared & 0.979 & 0.773 & 0.767 & 0.317 & 0.336 & 0.512 & 0.343 \\
\hline Country fixed effects & YES & YES & YES & YES & YES & YES & YES \\
\hline Time dummies & YES & YES & YES & YES & YES & YES & YES \\
\hline Excluding periods with jumps & YES & YES & YES & YES & YES & YES & YES \\
\hline \multicolumn{8}{|c|}{$\begin{array}{l}\text { Sources: Chinn and Ito (2006), Financial Flows Analytics (IMF, 2018a), Google Trends, World Development Indicators } \\
\text { (World Bank, 2018), World Economic Outlook (IMF, 2018e), and the authors' estimation. } \\
\text { Note. Sample period: } 2004-2016 \text {. Cluster-robust standard errors are reported in parentheses. Superscripts *, **, and *** } \\
\text { indicate statistical significance at the } 10 \text { percent, } 5 \text { percent, and } 1 \text { percent level, respectively. See Appendix I, Section E for } \\
\text { the methodology used to detect jumps. See Appendix Table } 1 \text { for country groupings and Appendix Table } 3 \text { for variable } \\
\text { definitions (most of variables are in natural logarithm or percent change) and data sources. LIDCs: low-income developing } \\
\text { countries; REER: real effective exchange rate; SVI: search volume index. }\end{array}$} \\
\hline
\end{tabular}




\section{Appendix Table 11. Regressions with lagged SVIs for LIDCs}

\begin{tabular}{|c|c|c|c|c|c|c|c|}
\hline Dependent variables & $\begin{array}{l}(1) \\
\text { Real } \\
\text { GDP }\end{array}$ & $\begin{array}{c}\text { (2) } \\
\text { Real } \\
\text { exports }\end{array}$ & $\begin{array}{c}\text { (3) } \\
\text { Tourist } \\
\text { arrivals }\end{array}$ & $\begin{array}{c}(4) \\
\text { Inflation }\end{array}$ & $\begin{array}{c}(5) \\
\text { Nominal } \\
\text { exchange } \\
\text { rate }\end{array}$ & $\begin{array}{c}6) \\
\text { Private } \\
\text { capital } \\
\text { inflows }\end{array}$ & $\begin{array}{c}\text { (7) } \\
\text { FDI } \\
\text { inflows }\end{array}$ \\
\hline SVI: Finance & $\begin{array}{c}0.00 \\
(0.02)\end{array}$ & $\begin{array}{l}-0.05 \\
(0.04)\end{array}$ & $\begin{array}{c}0.09 \\
(0.08)\end{array}$ & $\begin{array}{c}2.63 * * \\
(1.13)\end{array}$ & $\begin{array}{l}6.89^{* *} \\
(2.86)\end{array}$ & $\begin{array}{l}-0.14 \\
(0.32)\end{array}$ & $\begin{array}{l}-0.04 \\
(0.30)\end{array}$ \\
\hline SVI: Business and industrial & $\begin{array}{l}0.06 * * \\
(0.03)\end{array}$ & $\begin{array}{c}0.15 \\
(0.11)\end{array}$ & $\begin{array}{c}0.28 \\
(0.23)\end{array}$ & $\begin{array}{l}-3.04^{*} \\
(1.79)\end{array}$ & $\begin{array}{l}-0.87 \\
(4.29)\end{array}$ & $\begin{array}{c}0.15 \\
(0.58)\end{array}$ & $\begin{array}{l}1.16^{*} \\
(0.64)\end{array}$ \\
\hline SVI: Law and government & $\begin{array}{c}-0.08 * * * \\
(0.02)\end{array}$ & $\begin{array}{c}-0.20 * * * \\
(0.06)\end{array}$ & $\begin{array}{c}-0.40 * * * \\
(0.13)\end{array}$ & $\begin{array}{c}0.58 \\
(1.51)\end{array}$ & $\begin{array}{c}-6.78 * * \\
(2.55)\end{array}$ & $\begin{array}{c}0.17 \\
(0.27)\end{array}$ & $\begin{array}{l}-0.49 \\
(0.45)\end{array}$ \\
\hline SVI: Health & $\begin{array}{l}-0.02 * \\
(0.01)\end{array}$ & $\begin{array}{c}0.00 \\
(0.04)\end{array}$ & $\begin{array}{c}-0.27^{* *} \\
(0.11)\end{array}$ & $\begin{array}{l}2.14^{*} \\
(1.13)\end{array}$ & $\begin{array}{l}-0.57 \\
(1.61)\end{array}$ & $\begin{array}{l}-0.30 \\
(0.20)\end{array}$ & $\begin{array}{l}-0.47 \\
(0.30)\end{array}$ \\
\hline SVI: Travel & $\begin{array}{c}0.00 \\
(0.03) \\
\end{array}$ & $\begin{array}{c}0.04 \\
(0.06) \\
\end{array}$ & $\begin{array}{c}0.20 \\
(0.15) \\
\end{array}$ & $\begin{array}{c}-3.23^{* *} \\
(1.59) \\
\end{array}$ & $\begin{array}{l}-0.87 \\
(2.41) \\
\end{array}$ & $\begin{array}{l}-0.29 \\
(0.27) \\
\end{array}$ & $\begin{array}{c}0.29 \\
(0.33) \\
\end{array}$ \\
\hline SVI: Finance (lag) & $\begin{array}{l}-0.03 \\
(0.03)\end{array}$ & $\begin{array}{c}0.06 \\
(0.06)\end{array}$ & $\begin{array}{l}-0.16 \\
(0.10)\end{array}$ & $\begin{array}{c}0.78 \\
(1.11)\end{array}$ & $\begin{array}{c}3.70 \\
(2.44)\end{array}$ & $\begin{array}{l}-0.21 \\
(0.31)\end{array}$ & $\begin{array}{c}-0.13 \\
(0.33)\end{array}$ \\
\hline SVI: Business and industrial (lag) & $\begin{array}{l}0.05^{*} \\
(0.03)\end{array}$ & $\begin{array}{l}-0.02 \\
(0.09)\end{array}$ & $\begin{array}{c}0.05 \\
(0.09)\end{array}$ & $\begin{array}{c}1.19 \\
(1.87)\end{array}$ & $\begin{array}{l}-2.36 \\
(3.34)\end{array}$ & $\begin{array}{l}1.47 * * \\
(0.68)\end{array}$ & $\begin{array}{c}0.18 \\
(0.65)\end{array}$ \\
\hline SVI: Law and government (lag) & $\begin{array}{l}0.04 * * \\
(0.02)\end{array}$ & $\begin{array}{c}0.01 \\
(0.06)\end{array}$ & $\begin{array}{c}0.10 \\
(0.10)\end{array}$ & $\begin{array}{l}-1.66 \\
(1.35)\end{array}$ & $\begin{array}{c}1.20 \\
(2.58)\end{array}$ & $\begin{array}{l}-0.13 \\
(0.28)\end{array}$ & $\begin{array}{c}0.33 \\
(0.41)\end{array}$ \\
\hline SVI: Health (lag) & $\begin{array}{l}-0.03 * \\
(0.02)\end{array}$ & $\begin{array}{l}-0.01 \\
(0.04)\end{array}$ & $\begin{array}{c}0.04 \\
(0.09)\end{array}$ & $\begin{array}{l}-0.08 \\
(1.00)\end{array}$ & $\begin{array}{c}2.07 \\
(1.99)\end{array}$ & $\begin{array}{l}-0.48^{*} \\
(0.27)\end{array}$ & $\begin{array}{c}0.05 \\
(0.37)\end{array}$ \\
\hline SVI: Travel (lag) & $\begin{array}{c}0.01 \\
(0.02) \\
\end{array}$ & $\begin{array}{l}-0.02 \\
(0.06) \\
\end{array}$ & $\begin{array}{r}0.12 \\
(0.14) \\
\end{array}$ & $\begin{array}{c}0.21 \\
(1.37) \\
\end{array}$ & $\begin{array}{l}-2.28 \\
(2.25) \\
\end{array}$ & $\begin{array}{l}-0.24 \\
(0.35) \\
\end{array}$ & $\begin{array}{c}-0.75^{*} \\
(0.40) \\
\end{array}$ \\
\hline Control variables included & YES & YES & YES & YES & YES & YES & YES \\
\hline Observa & 597 & 587 & 535 & 595 & 620 & 423 & 499 \\
\hline Number of countries & 53 & 53 & 52 & 54 & 55 & 49 & 49 \\
\hline Adjusted R-squared & 0.960 & 0.799 & 0.731 & 0.317 & 0.323 & 0.361 & 0.277 \\
\hline Country fixed effects & YES & YES & YES & YES & YES & YES & YES \\
\hline Time dummies & YES & YES & YES & YES & YES & YES & YES \\
\hline Excluding periods with jumps & NO & NO & NO & NO & NO & NO & NO \\
\hline
\end{tabular}

Sources: Chinn and Ito (2006), Financial Flows Analytics (IMF, 2018a), Google Trends, World Development Indicators (World Bank, 2018), World Economic Outlook (IMF, 2018e), and the authors' estimation.

Note. Sample period: 2004-2016. Cluster-robust standard errors are reported in parentheses. Superscripts *, $* *$, and $* * *$ indicate statistical significance at the 10 percent, 5 percent, and 1 percent level, respectively. See Appendix Table 1 for country groupings and Appendix Table 3 for variable definitions (most of variables are in natural logarithm or percent change) and data sources. LIDCs: low-income developing countries; SVI: search volume index. 
Appendix Table 12. Regressions with domestically-made SVIs (DSVIs) for LIDCs

\begin{tabular}{|c|c|c|c|c|c|c|c|}
\hline Dependent variables & $\begin{array}{c}(1) \\
\text { Real } \\
\text { GDP }\end{array}$ & $\begin{array}{c}(2) \\
\text { Real } \\
\text { exports }\end{array}$ & $\begin{array}{c}\text { (3) } \\
\text { Tourist } \\
\text { arrivals }\end{array}$ & $\begin{array}{c}(4) \\
\text { Inflation }\end{array}$ & $\begin{array}{c}(5) \\
\text { Nominal } \\
\text { exchange } \\
\text { rate }\end{array}$ & $\begin{array}{c}(6) \\
\text { Private } \\
\text { capital } \\
\text { inflows } \\
\end{array}$ & $\begin{array}{c}\text { (7) } \\
\text { FDI } \\
\text { inflows }\end{array}$ \\
\hline SVI: Finance & $\begin{array}{c}0.01 \\
(0.02)\end{array}$ & $\begin{array}{l}-0.03 \\
(0.04)\end{array}$ & $\begin{array}{l}-0.03 \\
(0.10)\end{array}$ & $\begin{array}{l}2.99 * * \\
(1.18)\end{array}$ & $\begin{array}{l}7.01 * * \\
(2.73)\end{array}$ & $\begin{array}{l}-0.30 \\
(0.27)\end{array}$ & $\begin{array}{l}-0.36 \\
(0.32)\end{array}$ \\
\hline SVI: Business and industrial & $\begin{array}{l}0.07 * * \\
(0.03)\end{array}$ & $\begin{array}{l}0.10 \\
(0.07)\end{array}$ & $\begin{array}{c}0.30 \\
(0.24)\end{array}$ & $\begin{array}{l}-0.67 \\
(1.69)\end{array}$ & $\begin{array}{c}1.49 \\
(5.35)\end{array}$ & $\begin{array}{c}0.81 * * \\
(0.38)\end{array}$ & $\begin{array}{l}1.12^{*} \\
(0.58)\end{array}$ \\
\hline SVI: Law and government & $\begin{array}{c}-0.06^{* * *} * \\
(0.02)\end{array}$ & $\begin{array}{c}-0.11^{* *} \\
(0.05)\end{array}$ & $\begin{array}{c}-0.46^{* * *} \\
(0.13)\end{array}$ & $\begin{array}{l}-0.85 \\
(1.36)\end{array}$ & $\begin{array}{c}-8.93 * * * \\
(3.27)\end{array}$ & $\begin{array}{c}0.38 \\
(0.36)\end{array}$ & $\begin{array}{l}-0.14 \\
(0.33)\end{array}$ \\
\hline SVI: Health & $\begin{array}{c}-0.05^{* *} \\
(0.02)\end{array}$ & $\begin{array}{c}0.01 \\
(0.05)\end{array}$ & $\begin{array}{l}-0.16 \\
(0.11)\end{array}$ & $\begin{array}{c}2.17 \\
(1.31)\end{array}$ & $\begin{array}{c}2.15 \\
(2.27)\end{array}$ & $\begin{array}{c}-0.49^{*} \\
(0.28)\end{array}$ & $\begin{array}{l}-0.27 \\
(0.34)\end{array}$ \\
\hline SVI: Travel & $\begin{array}{c}0.01 \\
(0.01)\end{array}$ & $\begin{array}{l}-0.02 \\
(0.05)\end{array}$ & $\begin{array}{c}0.25^{* *} \\
(0.10)\end{array}$ & $\begin{array}{c}-3.85^{* *} \\
(1.55)\end{array}$ & $\begin{array}{l}-3.55 \\
(3.04)\end{array}$ & $\begin{array}{c}-0.48^{* *} \\
(0.21)\end{array}$ & $\begin{array}{l}-0.12 \\
(0.40)\end{array}$ \\
\hline DSVI: Finance & $\begin{array}{l}-0.02 \\
(0.01)\end{array}$ & $\begin{array}{l}-0.01 \\
(0.03)\end{array}$ & $\begin{array}{c}0.04 \\
(0.05)\end{array}$ & $\begin{array}{c}0.39 \\
(0.71)\end{array}$ & $\begin{array}{c}2.16 \\
(1.36)\end{array}$ & $\begin{array}{c}0.02 \\
(0.19)\end{array}$ & $\begin{array}{c}0.21 \\
(0.23)\end{array}$ \\
\hline DSVI: Business and industrial & $\begin{array}{c}0.01 \\
(0.01)\end{array}$ & $\begin{array}{c}0.01 \\
(0.05)\end{array}$ & $\begin{array}{l}-0.02 \\
(0.08)\end{array}$ & $\begin{array}{l}-2.20^{*} \\
(1.22)\end{array}$ & $\begin{array}{l}-3.18 \\
(2.77)\end{array}$ & $\begin{array}{c}0.28 \\
(0.26)\end{array}$ & $\begin{array}{c}0.35 \\
(0.29)\end{array}$ \\
\hline DSVI: Law and government & $\begin{array}{c}0.00 \\
(0.01)\end{array}$ & $\begin{array}{l}-0.07^{*} \\
(0.04)\end{array}$ & $\begin{array}{c}0.08 \\
(0.08)\end{array}$ & $\begin{array}{c}1.76 \\
(1.08)\end{array}$ & $\begin{array}{c}3.88 \\
(2.38)\end{array}$ & $\begin{array}{l}-0.22 \\
(0.31)\end{array}$ & $\begin{array}{l}-0.28 \\
(0.33)\end{array}$ \\
\hline DSVI: Health & $\begin{array}{c}0.01 \\
(0.01)\end{array}$ & $\begin{array}{l}-0.03 \\
(0.04)\end{array}$ & $\begin{array}{l}-0.05 \\
(0.05)\end{array}$ & $\begin{array}{l}-0.83 \\
(0.74)\end{array}$ & $\begin{array}{l}-1.94 \\
(1.46)\end{array}$ & $\begin{array}{l}0.15 \\
(0.17)\end{array}$ & $\begin{array}{l}-0.21 \\
(0.18)\end{array}$ \\
\hline DSVI: Travel & $\begin{array}{c}0.00 \\
(0.01) \\
\end{array}$ & $\begin{array}{c}0.09 \\
(0.06) \\
\end{array}$ & $\begin{array}{l}-0.01 \\
(0.07) \\
\end{array}$ & $\begin{array}{l}-0.01 \\
(1.04) \\
\end{array}$ & $\begin{array}{c}0.40 \\
(1.27) \\
\end{array}$ & $\begin{array}{l}-0.06 \\
(0.17) \\
\end{array}$ & $\begin{array}{l}-0.07 \\
(0.18) \\
\end{array}$ \\
\hline Control variables included & YES & YES & YES & YES & YES & YES & YES \\
\hline Observations & 592 & 581 & 532 & 590 & 617 & 435 & 504 \\
\hline Number of countries & 52 & 52 & 51 & 53 & 54 & 49 & 49 \\
\hline Adjusted R-squared & 0.966 & 0.828 & 0.728 & 0.319 & 0.316 & 0.462 & 0.343 \\
\hline Country fixed effects & YES & YES & YES & YES & YES & YES & YES \\
\hline Time dummies & YES & YES & YES & YES & YES & YES & YES \\
\hline Excluding periods with jumps & NO & NO & NO & NO & NO & NO & NO \\
\hline
\end{tabular}

Sources: Chinn and Ito (2006), Financial Flows Analytics (IMF, 2018a), Google Trends, World Development Indicators (World Bank, 2018), World Economic Outlook (IMF, 2018e), and the authors' estimation.

Note. Sample period: 2004-2016. Cluster-robust standard errors are reported in parentheses. Superscripts *, **, and *** indicate statistical significance at the 10 percent, 5 percent, and 1 percent level, respectively. See Appendix Table 1 for country groupings and Appendix Table 3 for variable definitions (most of variables are in natural logarithm or percent change) and data sources. LIDCs: low-income developing countries; SVI: search volume index. 


\section{Appendix Table 13. Summary statistics for EMEs}

\begin{tabular}{|c|c|c|c|c|c|c|c|}
\hline Variable & $25^{\text {th }}$ & $\begin{array}{l}\text { ercentile } \\
50^{\text {th }}\end{array}$ & $75^{\text {th }}$ & Mean & $\begin{array}{l}\text { Standard } \\
\text { deviation }\end{array}$ & $\begin{array}{c}\text { Number of } \\
\text { observations }\end{array}$ & $\begin{array}{c}\text { Number of } \\
\text { countries }\end{array}$ \\
\hline Google search volume index (SVI): All & -0.45 & 0.84 & 1.91 & 0.63 & 1.73 & 1,222 & 94 \\
\hline SVI: Finance & -1.64 & 0.07 & 1.20 & -0.25 & 2.00 & 1,222 & 94 \\
\hline SVI: Business and industrial & -1.29 & 0.11 & 1.66 & -0.01 & 2.01 & 1,222 & 94 \\
\hline SVI: Law and government & -0.65 & 1.06 & 2.21 & 0.75 & 1.84 & 1,222 & 94 \\
\hline SVI: Health & -0.67 & 0.70 & 1.90 & 0.57 & 1.80 & 1,222 & 94 \\
\hline SVI: Travel & -0.45 & 0.90 & 2.09 & 0.78 & 1.64 & 1,222 & 94 \\
\hline Foreign direct investment (FDI) inflows & 5.49 & 7.05 & 8.41 & 6.91 & 2.21 & 1,049 & 89 \\
\hline Non-FDI private capital inflows & 5.26 & 6.98 & 8.53 & 6.86 & 2.36 & 831 & 89 \\
\hline Total private capital inflows & 5.95 & 7.70 & 9.07 & 7.45 & 2.36 & 1,000 & 89 \\
\hline Total capital inflows & 5.95 & 7.72 & 9.12 & 7.49 & 2.34 & 994 & 89 \\
\hline Export price growth & -3.11 & 4.52 & 8.11 & 1.71 & 8.07 & 1,222 & 94 \\
\hline Import price growth & -2.94 & 4.47 & 8.46 & 1.97 & 8.30 & 1,222 & 94 \\
\hline Trading partners' growth & 2.22 & 3.29 & 4.61 & 3.31 & 2.24 & 1,222 & 94 \\
\hline REER (log level) & 4.54 & 4.60 & 4.64 & 4.59 & 0.16 & 1,188 & 92 \\
\hline REER (percent change, p.a.) & -2.04 & 0.66 & 4.21 & 1.19 & 7.62 & 1,184 & 92 \\
\hline Fiscal spending & 1.58 & 4.36 & 7.09 & 4.32 & 3.90 & 1,210 & 94 \\
\hline Inflation & 2.03 & 4.06 & 7.15 & 5.77 & 10.06 & 1,211 & 94 \\
\hline Nominal exchange rate & -1.01 & 0.00 & 4.16 & 2.17 & 10.19 & 1,215 & 94 \\
\hline Real exports & 1.17 & 2.67 & 3.76 & 2.46 & 1.99 & 1,057 & 87 \\
\hline Trade openness & 4.17 & 4.48 & 4.72 & 4.43 & 0.42 & 1,131 & 93 \\
\hline Age dependency ratio & 45.04 & 50.90 & 59.47 & 53.22 & 13.21 & 1,144 & 88 \\
\hline GDP (constant 2010 US\$) & 1.64 & 3.54 & 5.08 & 3.27 & 2.42 & 1,194 & 92 \\
\hline International tourism, number of arrivals & 12.67 & 14.07 & 15.44 & 13.95 & 1.94 & 1,134 & 92 \\
\hline International tourism, receipts & 19.64 & 20.92 & 22.20 & 20.80 & 1.88 & 1,130 & 91 \\
\hline Internet users (per 100 people) & 2.53 & 3.32 & 3.81 & 3.09 & 0.94 & 1,091 & 93 \\
\hline Capital account openness index & 0.17 & 0.45 & 0.88 & 0.51 & 0.35 & 1,026 & 86 \\
\hline Nighttime lights per area, HSW (2012) & -0.30 & 0.64 & 1.26 & 0.49 & 1.40 & 449 & 90 \\
\hline Nighttime lights per area, Rnightlights & 0.13 & 1.12 & 1.87 & 0.94 & 1.45 & 984 & 82 \\
\hline
\end{tabular}

Sources: Chinn and Ito (2006); Earth Observation Group; Financial Flows Analytics (IMF, 2018a); GADM (2018); Google Trends; Henderson, Storeygard, and Weil (2012); International Financial Statistics (IMF, 2018b); National Geophysical Data Center (with U.S. Air Force Weather Agency); World Development Indicators (World Bank, 2018); World Economic Outlook (IMF, 2018e); and the authors' calculation.

Note. Sample period: 2004-2016. See Appendix Table 1 for country groupings and Appendix Table 3 for variable definitions (most of variables are in natural logarithm or percent change) and data sources. Among EMEs, the nighttime light data exclude countries identified as outliers by Henderson, Storeygard, and Weil (2012, footnote 16, p. 1011; Bahrain, Equatorial Guinea, Serbia, Montenegro). For the data compiled by Rnightlights, several large economies are also excluded due to their heavy computational burden (Brazil, Chile, China, Indonesia, India, Mexico, Peru, Russia). EMEs: emerging market economies; REER: real effective exchange rate. 
Appendix Table 14. Regression Results for EMEs

\begin{tabular}{|c|c|c|c|c|c|c|c|}
\hline Dependent variables & $\begin{array}{l}(1) \\
\text { Real } \\
\text { GDP }\end{array}$ & $\begin{array}{c}(2) \\
\text { Real } \\
\text { exports }\end{array}$ & $\begin{array}{c}\text { (3) } \\
\text { Tourist } \\
\text { arrivals }\end{array}$ & $\begin{array}{c}(4) \\
\text { Inflation }\end{array}$ & $\begin{array}{c}(5) \\
\text { Nominal } \\
\text { exchange } \\
\text { rate }\end{array}$ & $\begin{array}{c}(6) \\
\text { Private } \\
\text { capital } \\
\text { inflows }\end{array}$ & $\begin{array}{c}\text { (7) } \\
\text { FDI } \\
\text { inflows }\end{array}$ \\
\hline SVI: Finance & $\begin{array}{c}0.01 \\
(0.01)\end{array}$ & $\begin{array}{c}0.01 \\
(0.02)\end{array}$ & $\begin{array}{c}0.03 \\
(0.05)\end{array}$ & $\begin{array}{c}1.13 \\
(1.43)\end{array}$ & $\begin{array}{l}3.71 * * \\
(1.72)\end{array}$ & $\begin{array}{c}0.25 \\
(0.16)\end{array}$ & $\begin{array}{c}0.22 \\
(0.14)\end{array}$ \\
\hline SVI: Business and industrial & $\begin{array}{l}-0.02^{*} \\
(0.01)\end{array}$ & $\begin{array}{l}-0.01 \\
(0.03)\end{array}$ & $\begin{array}{l}-0.01 \\
(0.06)\end{array}$ & $\begin{array}{c}4.65 \\
(4.59)\end{array}$ & $\begin{array}{c}3.23 \\
(3.63)\end{array}$ & $\begin{array}{l}-0.30 \\
(0.21)\end{array}$ & $\begin{array}{l}-0.20 \\
(0.22)\end{array}$ \\
\hline SVI: Law and government & $\begin{array}{l}-0.00 \\
(0.01)\end{array}$ & $\begin{array}{l}-0.02 \\
(0.02)\end{array}$ & $\begin{array}{l}-0.08^{*} \\
(0.05)\end{array}$ & $\begin{array}{l}-3.75^{*} \\
(2.12)\end{array}$ & $\begin{array}{l}-3.96 \\
(2.38)\end{array}$ & $\begin{array}{c}0.13 \\
(0.27)\end{array}$ & $\begin{array}{c}0.10 \\
(0.22)\end{array}$ \\
\hline SVI: Health & $\begin{array}{l}-0.01 \\
(0.01)\end{array}$ & $\begin{array}{l}-0.03 \\
(0.03)\end{array}$ & $\begin{array}{l}-0.02 \\
(0.05)\end{array}$ & $\begin{array}{l}-1.12 \\
(1.99)\end{array}$ & $\begin{array}{l}-2.26 \\
(2.38)\end{array}$ & $\begin{array}{l}-0.15 \\
(0.29)\end{array}$ & $\begin{array}{c}0.02 \\
(0.21)\end{array}$ \\
\hline SVI: Travel & $\begin{array}{c}0.01 \\
(0.01)\end{array}$ & $\begin{array}{c}0.04 \\
(0.03)\end{array}$ & $\begin{array}{c}0.20^{* * * *} \\
(0.05)\end{array}$ & $\begin{array}{l}-1.36 \\
(1.31)\end{array}$ & $\begin{array}{c}1.44 \\
(2.23)\end{array}$ & $\begin{array}{l}-0.04 \\
(0.21)\end{array}$ & $\begin{array}{l}-0.12 \\
(0.21)\end{array}$ \\
\hline Lagged dependent variable & $\begin{array}{c}0.91 * * * \\
(0.03)\end{array}$ & $\begin{array}{c}0.80 * * * \\
(0.03)\end{array}$ & $\begin{array}{c}0.75^{* * *} \\
(0.03)\end{array}$ & $\begin{array}{c}0.43 * * * \\
(0.09)\end{array}$ & $\begin{array}{c}0.29 * * * \\
(0.04)\end{array}$ & $\begin{array}{c}0.29 * * * \\
(0.07)\end{array}$ & $\begin{array}{c}0.36^{* * *} \\
(0.10)\end{array}$ \\
\hline Population (lag) & $\begin{array}{l}0.00 \\
(0.03)\end{array}$ & $\begin{array}{l}-0.01 \\
(0.08)\end{array}$ & $\begin{array}{l}-0.37^{*} \\
(0.21)\end{array}$ & $\begin{array}{l}-3.41 \\
(3.37)\end{array}$ & $\begin{array}{c}-9.89 * * \\
(4.09)\end{array}$ & $\begin{array}{c}0.10 \\
(1.10)\end{array}$ & $\begin{array}{l}-1.03 \\
(0.90)\end{array}$ \\
\hline Internet users (lag) & $\begin{array}{c}0.00 \\
(0.01)\end{array}$ & $\begin{array}{c}0.00 \\
(0.01)\end{array}$ & $\begin{array}{l}-0.00 \\
(0.02)\end{array}$ & $\begin{array}{l}-0.20 \\
(0.52)\end{array}$ & $\begin{array}{c}1.05 \\
(0.99)\end{array}$ & $\begin{array}{c}0.06 \\
(0.13)\end{array}$ & $\begin{array}{l}0.01 \\
(0.11)\end{array}$ \\
\hline Real GDP (lag) & & $\begin{array}{l}-0.03 \\
(0.07)\end{array}$ & $\begin{array}{l}0.29 * * \\
(0.13)\end{array}$ & $\begin{array}{l}-2.62 \\
(4.56)\end{array}$ & $\begin{array}{l}-2.22 \\
(4.15)\end{array}$ & $\begin{array}{c}1.53 * * * \\
(0.51)\end{array}$ & $\begin{array}{c}1.37 * * * \\
(0.39)\end{array}$ \\
\hline Trade openness (lag) & $\begin{array}{c}0.01 \\
(0.02)\end{array}$ & $\begin{array}{c}0.00 \\
(0.04)\end{array}$ & $\begin{array}{c}0.10 \\
(0.08)\end{array}$ & $\begin{array}{c}2.67 \\
(2.19)\end{array}$ & $\begin{array}{c}-11.02^{* * *} \\
(3.13)\end{array}$ & $\begin{array}{l}1.04 * * \\
(0.43)\end{array}$ & $\begin{array}{l}0.52 * * \\
(0.25)\end{array}$ \\
\hline Fiscal spending (lag) & $\begin{array}{l}-0.02 \\
(0.01)\end{array}$ & $\begin{array}{l}-0.04 \\
(0.03)\end{array}$ & $\begin{array}{c}0.03 \\
(0.06)\end{array}$ & $\begin{array}{c}4.08 \\
(3.70)\end{array}$ & $\begin{array}{c}2.50 \\
(2.79)\end{array}$ & $\begin{array}{l}-0.13 \\
(0.17)\end{array}$ & $\begin{array}{l}-0.08 \\
(0.14)\end{array}$ \\
\hline REER, log level (lag) & $\begin{array}{c}-0.05 * * * \\
(0.02)\end{array}$ & $\begin{array}{l}-0.05 \\
(0.05)\end{array}$ & $\begin{array}{l}-0.09 \\
(0.11)\end{array}$ & & & $\begin{array}{l}0.59 * \\
(0.33)\end{array}$ & $\begin{array}{l}0.16 \\
(0.33)\end{array}$ \\
\hline REER, percent change (lag) & & & & $\begin{array}{l}-0.02 \\
(0.08)\end{array}$ & & & \\
\hline Inflation (lag) & $\begin{array}{c}-0.00 * * * \\
(0.00)\end{array}$ & $\begin{array}{c}-0.00 * * \\
(0.00)\end{array}$ & $\begin{array}{c}0.01 \\
(0.00)\end{array}$ & & $\begin{array}{l}-0.09 \\
(0.09)\end{array}$ & $\begin{array}{l}-0.01 \\
(0.01)\end{array}$ & $\begin{array}{l}-0.00 \\
(0.01)\end{array}$ \\
\hline Trading partners' growth (lag) & $\begin{array}{l}-0.00 \\
(0.00)\end{array}$ & $\begin{array}{l}-0.00 \\
(0.00)\end{array}$ & $\begin{array}{c}0.01 \\
(0.01)\end{array}$ & $\begin{array}{c}0.02 \\
(0.16)\end{array}$ & $\begin{array}{c}0.34 \\
(0.28)\end{array}$ & $\begin{array}{l}0.07 * * \\
(0.03)\end{array}$ & $\begin{array}{l}0.04 * \\
(0.02)\end{array}$ \\
\hline Export price growth (lag) & $\begin{array}{c}0.00 * * * \\
(0.00)\end{array}$ & $\begin{array}{c}0.00 \\
(0.00)\end{array}$ & $\begin{array}{l}-0.00 \\
(0.00)\end{array}$ & & & $\begin{array}{l}0.03 * \\
(0.02)\end{array}$ & $\begin{array}{c}0.01 \\
(0.01)\end{array}$ \\
\hline Import price growth (lag) & & & & $\begin{array}{c}0.09 \\
(0.11)\end{array}$ & $\begin{array}{c}0.16 \\
(0.15)\end{array}$ & & \\
\hline Capital account openness (lag) & $\begin{array}{l}-0.02 \\
(0.01)\end{array}$ & $\begin{array}{c}0.01 \\
(0.03)\end{array}$ & $\begin{array}{l}-0.03 \\
(0.05)\end{array}$ & $\begin{array}{c}-3.10^{* *} \\
(1.33)\end{array}$ & $\begin{array}{c}0.32 \\
(2.40)\end{array}$ & $\begin{array}{c}-0.88 * * * \\
(0.29)\end{array}$ & $\begin{array}{c}-0.94 * * * \\
(0.28)\end{array}$ \\
\hline Age dependency ratio (lag) & $\begin{array}{l}-0.00 \\
(0.00) \\
\end{array}$ & $\begin{array}{c}-0.00^{* *} \\
(0.00) \\
\end{array}$ & $\begin{array}{l}-0.00 \\
(0.00) \\
\end{array}$ & $\begin{array}{l}-0.07 \\
(0.07) \\
\end{array}$ & $\begin{array}{c}0.18 \\
(0.12) \\
\end{array}$ & $\begin{array}{c}0.01 \\
(0.01) \\
\end{array}$ & $\begin{array}{l}-0.01 \\
(0.01)\end{array}$ \\
\hline Observations & 976 & 938 & 923 & 975 & 978 & 753 & 826 \\
\hline Number of countries & 80 & 77 & 79 & 80 & 80 & 75 & 75 \\
\hline Adjusted R-squared & 0.966 & 0.829 & 0.790 & 0.271 & 0.329 & 0.285 & 0.316 \\
\hline Country fixed effects & YES & YES & YES & YES & YES & YES & YES \\
\hline Time dummies & YES & YES & YES & YES & YES & YES & YES \\
\hline Excluding periods of jumps & $\mathrm{NO}$ & $\mathrm{NO}$ & NO & NO & NO & NO & NO \\
\hline
\end{tabular}

Sources: Chinn and Ito (2006), Financial Flows Analytics (IMF, 2018a), Google Trends, World Development Indicators (World Bank, 2018), World Economic Outlook (IMF, 2018e), and the authors' estimation.

Note. Sample period: 2004-2016. Cluster-robust standard errors are reported in parentheses. Superscripts *, **, and *** indicate statistical significance at the 10 percent, 5 percent, and 1 percent level, respectively. See Appendix Table 1 for country groupings and Appendix Table 3 for variable definitions (most of variables are in natural logarithm or percent change) and data sources. EMEs: emerging market economies; REER: real effective exchange rate; SVI: search volume index. 